Energy Resources Program

\title{
National Assessment of Carbon Dioxide Enhanced Oil Recovery and Associated Carbon Dioxide Retention Resources-Results
}

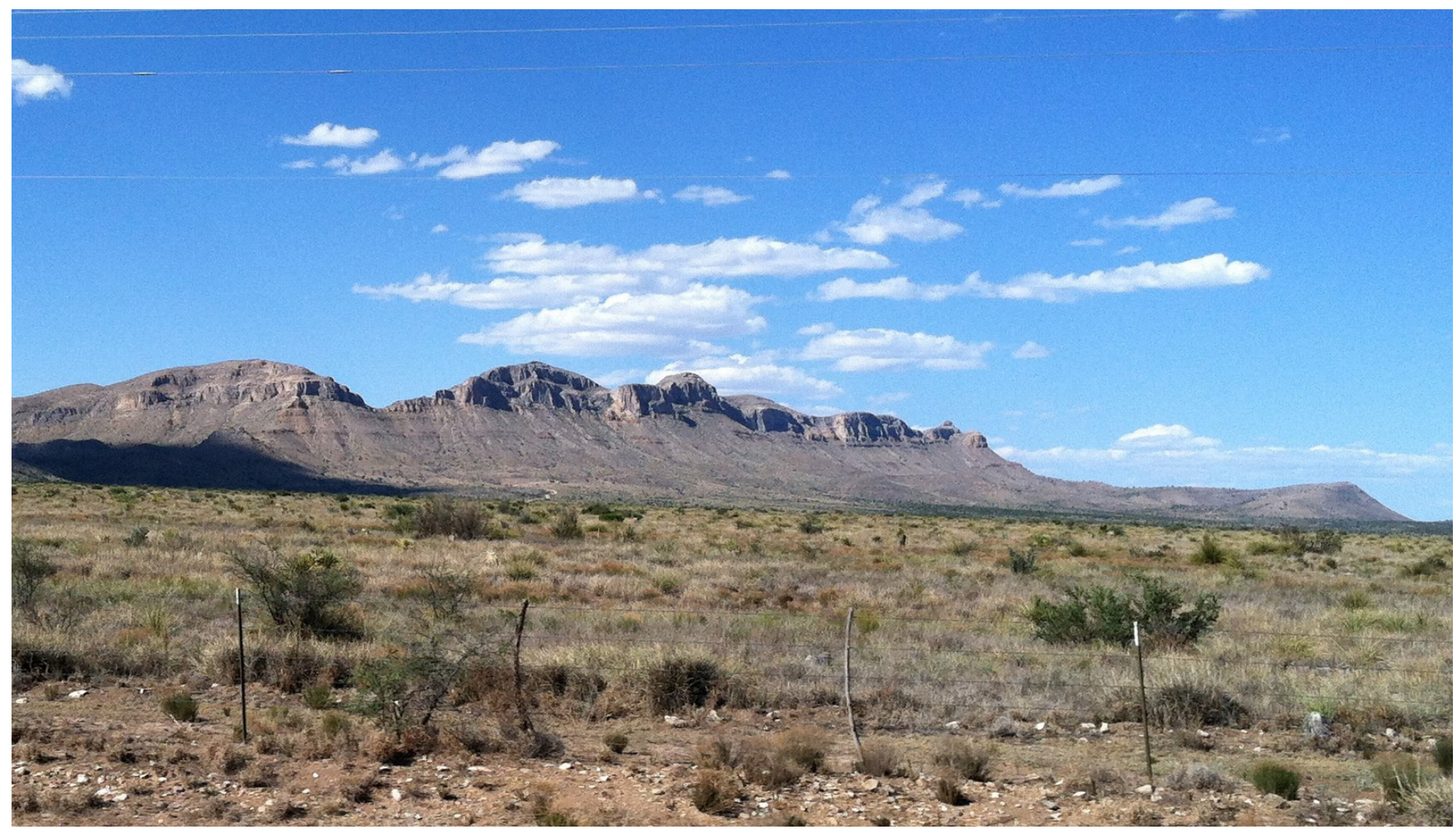

Circular 1489 
Cover. View of outcrops near Cathedral Mountain at the southern margin of the Permian Basin in Texas. Rocks exposed here are equivalent in age to Permian reservoirs that are undergoing carbon dioxide enhanced oil recovery operations in the central part of the Permian Basin. Photograph by Peter D. Warwick, U.S. Geological Survey, May 10, 2016. 
Energy Resources Program

\section{National Assessment of Carbon Dioxide Enhanced Oil Recovery and Associated Carbon Dioxide Retention Resources- Results}

By Peter D. Warwick, Emil D. Attanasi, Madalyn S. Blondes, Sean T. Brennan, Marc L. Buursink, Steven M. Cahan, Colin A. Doolan, Philip A. Freeman, C. Özgen Karacan, Celeste D. Lohr, Matthew D. Merrill, Ricardo A. Olea, Jenna L. Shelton, Ernie R. Slucher, and Brian A. Varela

Circular 1489 


\section{U.S. Geological Survey, Reston, Virginia: 2022}

For more information on the USGS — the Federal source for science about the Earth, its natural and living resources, natural hazards, and the environment-visit https://www.usgs.gov or call 1-888-ASK-USGS.

For an overview of USGS information products, including maps, imagery, and publications, visit https://store.usgs.gov.

Any use of trade, firm, or product names is for descriptive purposes only and does not imply endorsement by the U.S. Government.

Although this information product, for the most part, is in the public domain, it also may contain copyrighted materials as noted in the text. Permission to reproduce copyrighted items must be secured from the copyright owner.

Suggested citation:

Warwick, P.D., Attanasi, E.D., Blondes, M.S., Brennan, S.T., Buursink, M.L., Cahan, S.M., Doolan, C.A., Freeman, P.A., Karacan, C.Ö., Lohr, C.D., Merrill, M.D., Olea, R.A., Shelton, J.L., Slucher, E.R., and Varela, B.A., 2022, National assessment of carbon dioxide enhanced oil recovery and associated carbon dioxide retention resources-Results: U.S. Geological Survey Circular 1489, 39 p., https://doi.org/10.3133/cir1489.

Associated data for this publication:

Warwick, P.D., Attanasi, E.D., Blondes, M.S., Brennan, S.T., Buursink, M.L., Cahan, S.M., Doolan, C.A., Freeman, P.A., Karacan, C.Ö., Lohr, C.D., Merrill, M.D., Olea, R.A., Shelton, J.L., Slucher, E.R., and Varela, B.A., 2022, National assessment of carbon dioxide enhanced oil recovery and associated carbon dioxide retention resourcesData: U.S. Geological Survey data release, https://doi.org/10.5066/P9AG37KI. 


\section{Acknowledgments}

We wish to thank Douglas Patchen, West Virginia Geological and Economic Survey, for contributing data that aided in this assessment. We thank all of the participants in the May 2011 Carbon Dioxide and Associated Carbon Sequestration Workshop at Stanford University, California, particularly Sally Benson and the members of the Stanford Center for Carbon Storage, School of Earth, Energy and Environmental Sciences, Stanford University, for their help in facilitating the workshop. The content and presentation of this report benefited greatly from the technical reviews by James Coleman, Stephanie Gaswirth, and Carla Brezinski. Elizabeth Good and Ethan Whitecotton assisted us during the publication process. 



\section{Contents}

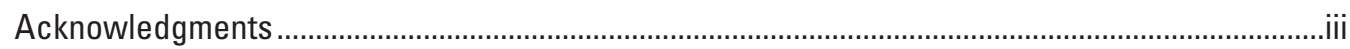

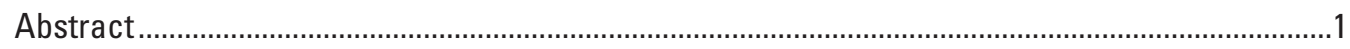

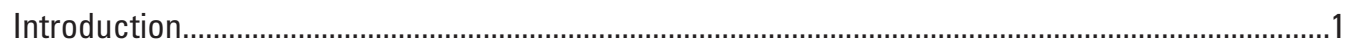

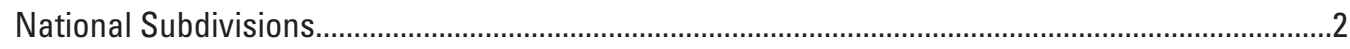

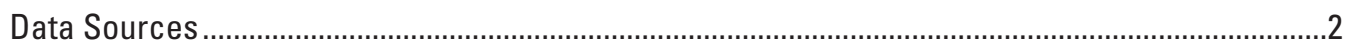

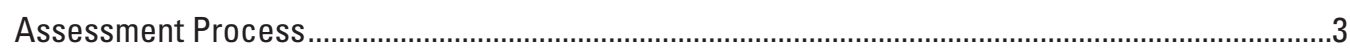

Assessment Assumptions and Constraints ........................................................................

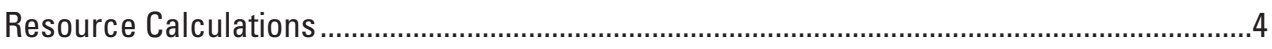

Aggregation Dependencies and General Guidelines .............................................................

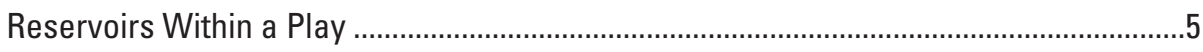

Plays Within a Province .............................................................................................

Correlations Among Provinces Within a Region and Among Regions ..............................

Results of the Assessment of Carbon Dioxide Enhanced Oil Recovery and Associated Carbon Dioxide Retention Resources ...............................................................................................

Carbon Dioxide Enhanced Oil Recovery .............................................................................6

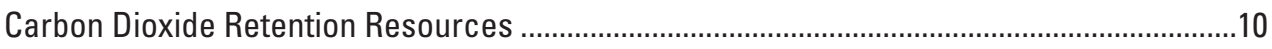

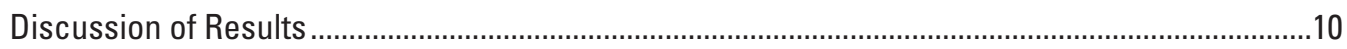

Comparison of Results With Findings From Previous Assessments ............................................19

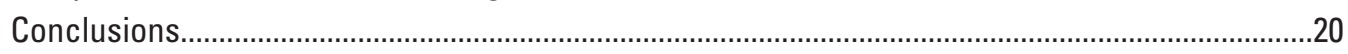

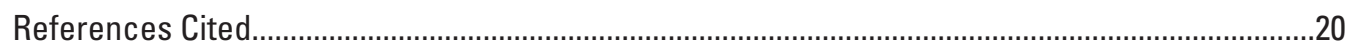

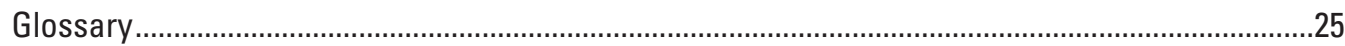

\section{Figures}

1. Graphs showing probabilities for estimates of national technically recoverable volumes of oil that could be produced with carbon dioxide enhanced oil recovery $\left(\mathrm{CO}_{2}-\mathrm{EOR}\right)$ and of the national total mass of associated subsurface $\mathrm{CO}_{2}$ that could be stored (retained) with the application of $\mathrm{CO}_{2}-\mathrm{EOR}$

2. Pie charts showing regional mean estimates by the U.S. Geological Survey in 2020 of $(A)$ technically recoverable volumes of oil that could be produced with the application of the carbon dioxide enhanced oil recovery $\left(\mathrm{CO}_{2}-\mathrm{EOR}\right)$ process and $(B)$ masses of associated subsurface carbon dioxide $\left(\mathrm{CO}_{2}\right)$ that could be stored (retained) with the application of the $\mathrm{CO}_{2}$-EOR process in existing reservoirs underlying onshore and State waters areas of the conterminous United States.

3. Maps of the conterminous United States and bar graphs showing regional estimates by the U.S. Geological Survey in 2020 of $(A)$ technically recoverable volumes of oil, in millions of petroleum barrels (MMbbl), that could be produced with the application of the carbon dioxide enhanced oil recovery $\left(\mathrm{CO}_{2}-\mathrm{EOR}\right)$ process and $(B)$ masses of associated subsurface carbon dioxide $\left(\mathrm{CO}_{2}\right)$, in millions of metric tons (Mt), that could be stored (retained) with the application of the $\mathrm{CO}_{2}$-EOR process in existing reservoirs underlying onshore and State waters areas of the conterminous United States.....................................................................................12 
4. Cumulative probability graphs showing the regional results of a probabilistic assessment by the U.S. Geological Survey in 2020 of $(A)$ technically recoverable volumes of oil, in millions of petroleum barrels ( $\mathrm{MMbbl})$, that could be produced with the application of the carbon dioxide enhanced oil recovery $\left(\mathrm{CO}_{2}\right.$-EOR) process and $(B)$ masses of associated subsurface carbon dioxide $\left(\mathrm{CO}_{2}\right)$, in millions of metric tons (Mt), that could be stored (retained) with the application of the $\mathrm{CO}_{2}$-EOR process in existing reservoirs underlying onshore and State waters areas of the conterminous United States

5. Maps of the conterminous United States showing 33 petroleum provinces that were assessed by the U.S. Geological Survey in 2020 for $(A)$ mean technically recoverable volumes of oil, in millions of petroleum barrels (MMbbl), that could be produced with the application of the carbon dioxide enhanced oil recovery $\left(\mathrm{CO}_{2}\right.$-EOR) process and $(B)$ mean masses of associated subsurface carbon dioxide $\left(\mathrm{CO}_{2}\right)$, in millions of metric tons $(\mathrm{Mt})$, that could be stored (retained) with the application of the $\mathrm{CO}_{2}$-EOR process in existing reservoirs underlying onshore and State waters areas of the conterminous United States

6. Graphs showing the probability distributions for the provinces estimated by the U.S. Geological Survey in 2020 for $(A)$ technically recoverable volumes of oil, in millions of petroleum barrels (MMbbl), that could be produced with the application of the carbon dioxide enhanced oil recovery $\left(\mathrm{CO}_{2}-\mathrm{EOR}\right)$ process and $(B)$ masses of associated carbon dioxide $\left(\mathrm{CO}_{2}\right)$, in millions of metric tons $(\mathrm{Mt})$, that could be stored (retained) with the application of $\mathrm{CO}_{2}$-EOR for each assessed province in the conterminous United States

\section{Tables}

[Table 6 is at the end of the report]

1. Ranges of values used for correlation coefficients to obtain play, province, region, and national distributions for the conterminous United States.

2. Values used for the correlation of reservoirs within a play based on pairs of reservoir shadow codes for porosity ( () ) and initial oil saturation (SOI) reported in the Comprehensive Resource Database (CRD) of Carolus and others (2017).

3. Correlation values used for the aggregation of plays within a province, provinces within a region, and regions within the conterminous United States (CONUS).

4. Total estimated volume of oil that could be produced with carbon dioxide enhanced oil recovery $\left(\mathrm{CO}_{2}-\mathrm{EOR}\right)$ and total mass of associated carbon dioxide $\left(\mathrm{CO}_{2}\right)$ that could be stored (retained) in existing reservoirs underlying onshore and State waters areas of the conterminous United States

5. Estimated volume of oil that could be produced with carbon dioxide enhanced oil recovery $\left(\mathrm{CO}_{2}\right.$-EOR) and estimated mass of associated carbon dioxide $\left(\mathrm{CO}_{2}\right)$ that could be stored (retained) in existing reservoirs underlying onshore and State waters areas of the conterminous United States, aggregated by region and province.

6. Estimated volume of oil that could be produced with carbon dioxide enhanced oil recovery $\left(\mathrm{CO}_{2}\right.$-EOR) and estimated mass of associated carbon dioxide $\left(\mathrm{CO}_{2}\right)$ that could be stored (retained) in existing reservoirs underlying onshore and State waters areas of the conterminous United States, aggregated by province and play 


\section{Conversion Factors}

\begin{tabular}{|c|c|c|}
\hline Multiply & By & To obtain \\
\hline \multicolumn{3}{|c|}{ Length } \\
\hline foot $(\mathrm{ft})$ & 0.3048 & meter $(\mathrm{m})$ \\
\hline \multicolumn{3}{|c|}{ Area } \\
\hline square inch $\left(\right.$ in $\left.^{2}\right)$ & 6.452 & square centimeter $\left(\mathrm{cm}^{2}\right)$ \\
\hline \multicolumn{3}{|c|}{ Volume } \\
\hline barrel (bbl; petroleum, 1 barrel = 42 gallons $)$ & 0.1590 & cubic meter $\left(\mathrm{m}^{3}\right)$ \\
\hline stock tank barrel (STB) & 0.1590 & cubic meter $\left(\mathrm{m}^{3}\right)$ \\
\hline thousand barrels petroleum (Mbbl) & 0.1590 & thousand cubic meters $\left(\mathrm{m}^{3}\right)$ \\
\hline million barrels petroleum (MMbbl) & 0.1590 & million cubic meters $\left(\mathrm{m}^{3}\right)$ \\
\hline standard cubic foot $\left(\mathrm{cf}, \mathrm{ft}^{3}\right)$ & 0.02832 & standard cubic meter $\left(\mathrm{m}^{3}\right)$ \\
\hline thousand cubic feet (Mcf, 1,000 $\mathrm{ft}^{3}$ ) & 28.32 & cubic meter $\left(\mathrm{m}^{3}\right)$ \\
\hline $\begin{array}{l}\text { thousand standard cubic feet (Mscf) of natural } \\
\text { gas at standard conditions of } 60 \text { degrees } \\
\text { Fahrenheit }\left({ }^{\circ} \mathrm{F}\right) \text { and } 14.7 \text { pound-force per } \\
\text { square inch, absolute (psia) }\end{array}$ & 28.31 & $\begin{array}{l}\text { cubic meters }\left(\mathrm{m}^{3}\right) \text { of natural } \\
\text { gas at standard conditions of } \\
15 \text { degrees Celsius }\left({ }^{\circ} \mathrm{C}\right) \text { and } \\
101.325 \text { kilopascals }(\mathrm{kPa})\end{array}$ \\
\hline $\begin{array}{l}\text { thousand standard cubic feet (Mscf) of } \\
\text { carbon dioxide }\left(\mathrm{CO}_{2}\right) \text { at standard condi- } \\
\text { tions of } 60 \text { degrees Fahrenheit }\left({ }^{\circ} \mathrm{F}\right) \\
\text { and } 14.7 \text { pound-force per square inch, } \\
\text { absolute (psia) }\end{array}$ & 0.0529 & $\begin{array}{l}\text { metric ton }(\mathrm{t}) \text { of carbon dioxide } \\
\left(\mathrm{CO}_{2}\right) \text { at standard conditions } \\
\text { of } 15 \text { degrees Celsius }\left({ }^{\circ} \mathrm{C}\right) \text { and } \\
101.325 \text { kilopascals }(\mathrm{kPa})\end{array}$ \\
\hline million cubic feet (MMcf) & 28,317 & cubic meter $\left(\mathrm{m}^{3}\right)$ \\
\hline billion cubic feet (Bcf) & $28,316,847$ & cubic meter $\left(\mathrm{m}^{3}\right)$ \\
\hline cubic meter $\left(\mathrm{m}^{3}\right)$ & 6.290 & $\begin{array}{l}\text { barrel (bbl; petroleum, } \\
1 \text { barrel = } 42 \text { gallons) }\end{array}$ \\
\hline \multicolumn{3}{|c|}{ Mass } \\
\hline pound, avoirdupois (lb) & 0.4536 & kilogram (kg) \\
\hline ton, short $(2,000 \mathrm{lb})$ & 0.9072 & megagram $(\mathrm{Mg})$ \\
\hline ton, long $(2,240 \mathrm{lb})$ & 1.016 & megagram (Mg) \\
\hline ton, metric $(2,204.62 \mathrm{lb})$ & 1.000 & megagram $(\mathrm{Mg})$ \\
\hline milligram (mg) & 0.00003527 & ounce, avoirdupois (oz) \\
\hline kilogram (kg) & 2.205 & pound avoirdupois (lb) \\
\hline megagram $(\mathrm{Mg})=1$ metric ton $(\mathrm{t})(1,000 \mathrm{~kg})$ & 1.102 & ton, short $(2,000 \mathrm{lb})$ \\
\hline megagram $(\mathrm{Mg})$ & 0.9842 & ton, long $(2,240 \mathrm{lb})$ \\
\hline million metric tons $=1$ megaton $(\mathrm{Mt})$ & 1.102 & million short tons \\
\hline billion metric tons $=1$ gigaton $(\mathrm{Gt})$ & 1.102 & billion short tons \\
\hline
\end{tabular}

Temperature in degrees Celsius $\left({ }^{\circ} \mathrm{C}\right)$ may be converted to degrees Fahrenheit $\left({ }^{\circ} \mathrm{F}\right)$ as follows:

$$
{ }^{\circ} \mathrm{F}=\left(1.8 \times{ }^{\circ} \mathrm{C}\right)+32 \text {. }
$$

Temperature in degrees Fahrenheit $\left({ }^{\circ} \mathrm{F}\right)$ may be converted to degrees Celsius $\left({ }^{\circ} \mathrm{C}\right)$ as follows:

$$
{ }^{\circ} \mathrm{C}=\left({ }^{\circ} \mathrm{F}-32\right) / 1.8 \text {. }
$$




\section{Abbreviations}

\begin{tabular}{ll}
$\varnothing$ & porosity, expressed as a volume, fraction, or percentage of the rock \\
Bbbl & billion petroleum barrels \\
bbl & petroleum barrel or barrels \\
BOEM & Bureau of Ocean Energy Management \\
CCUS & carbon capture, use, and storage \\
CO $_{2}$ & carbon dioxide \\
$\mathrm{CO}_{2}$-EOR & carbon dioxide enhanced oil recovery \\
CRD & Comprehensive Resource Database \\
EOR & enhanced oil recovery \\
EOR & incremental oil volume produced by enhanced oil recovery \\
Gt & gigaton = billion metric tons \\
IHS & IHS Inc. became IHS Markit, Inc. in 2016 \\
$k$ & permeability, in darcies or millidarcies \\
MMbbl & millions of petroleum barrels \\
Mscf & thousands of standard cubic feet \\
Mt & megaton = million metric tons \\
NOGA & National Oil and Gas Assessment \\
OOIP & original oil in place, in thousands of stock tank barrels \\
$R F$ & recovery factor for oil or gas \\
ROZ & residual oil zone \\
Scf & standard cubic foot \\
SOI & initial or original oil saturation, expressed as a fraction \\
STB & stock tank barrel \\
U.S. & United States \\
USGS & U.S. Geological Survey \\
$V D P$ & Dykstra-Parsons coefficient \\
& \\
\hline &
\end{tabular}




\title{
National Assessment of Carbon Dioxide Enhanced Oil Recovery and Associated Carbon Dioxide Retention Resources-Results
}

\author{
By Peter D. Warwick, Emil D. Attanasi, Madalyn S. Blondes, Sean T. Brennan, Marc L. Buursink, \\ Steven M. Cahan, Colin A. Doolan, Philip A. Freeman, C. Özgen Karacan, Celeste D. Lohr, \\ Matthew D. Merrill, Ricardo A. Olea, Jenna L. Shelton, Ernie R. Slucher, and Brian A. Varela
}

\section{Abstract}

In 2020, the U.S. Geological Survey (USGS) completed a probabilistic assessment of the volume of technically recoverable oil resources available if current carbon dioxide enhanced oil recovery $\left(\mathrm{CO}_{2}\right.$-EOR) technologies were applied to amenable oil reservoirs underlying the onshore and State waters areas of the conterminous United States. The assessment also includes estimates of the mass of $\mathrm{CO}_{2}$ that could be stored (retained) as a result of $\mathrm{CO}_{2}$-EOR activities. The USGS assessment team evaluated more than 3,500 oil reservoirs that were miscible to injected $\mathrm{CO}_{2}$. The assessed reservoirs are in 185 previously defined USGS plays in 33 petroleum provinces of 7 national regions. The assessment team estimated that the technically recoverable oil associated with $\mathrm{CO}_{2}$-EOR ranges from approximately 25,000 million barrels (MMbbl) at the $\mathrm{P}_{5}$ percentile to as much as $32,000 \mathrm{MMbbl}$ at the $\mathrm{P}_{95}$ percentile, with a mean of 29,000 MMbbl. The associated $\mathrm{CO}_{2}$ retention ranges from approximately 7,400 million metric tons $(\mathrm{Mt})$ at the $\mathrm{P}_{5}$ percentile to as much as $9,500 \mathrm{Mt}$ at the $\mathrm{P}_{95}$ percentile, with a mean of 8,400 Mt. The West Texas and Eastern New Mexico region and the Gulf Coast region together contain 60 percent of the mean assessed $\mathrm{CO}_{2}$-EOR oil potential and 61 percent of the mean assessed $\mathrm{CO}_{2}$ retention. Other regions with significant resource potential include the Midcontinent region and Rocky Mountains and Northern Great Plains region.

\section{Introduction}

The Energy Independence and Security Act of 2007 (U.S. Congress, 2007) authorized the U.S. Geological Survey (USGS) to conduct a national assessment of geologic storage resources for carbon dioxide $\left(\mathrm{CO}_{2}\right)$ and requested the USGS to estimate the "potential volumes of oil and gas recoverable by injection and sequestration of industrial carbon dioxide in potential sequestration formations" (42 U.S.C. 17271(b)(4)). The USGS developed a probability-based methodology to assess the Nation's technically accessible geologic storage resources available for sequestration of $\mathrm{CO}_{2}$ (Brennan and others, 2010; Blondes, Brennan, and others, 2013) and published the results of the assessment (U.S. Geological Survey Geologic Carbon Dioxide Storage Resources Assessment Team, 2013a, b, c).

A workshop on developing a methodology to assess $\mathrm{CO}_{2}$-enhanced oil recovery $\left(\mathrm{CO}_{2}\right.$-EOR) potential and associated carbon storage was held at Stanford University, California, in May 2011, to seek advice from academia, natural resource agencies and laboratories of the Federal Government, State and international geologic surveys, and representatives from the oil and gas industry (Verma and Warwick, 2011). Following the workshop recommendations, the USGS developed a national database that contains the geologic and engineering parameters to screen oil reservoirs amenable to $\mathrm{CO}_{2}$-EOR methods (Carolus and others, 2017). In 2019, the USGS published a probabilistic methodology for assessing oil reservoirs for their technically recoverable hydrocarbon potential associated with $\mathrm{CO}_{2}$-EOR (Warwick and others, 2019). Also included in the methodology is a way to estimate the associated storage of $\mathrm{CO}_{2}$ in the reservoirs after the completion of the $\mathrm{CO}_{2}$-EOR process.

The use of $\mathrm{CO}_{2}$-EOR techniques can increase the recoverable hydrocarbon resource volumes. Because some of the injected $\mathrm{CO}_{2}$ is retained in the reservoir, use of anthropogenic $\mathrm{CO}_{2}$ in the EOR process could potentially help reduce the amount of $\mathrm{CO}_{2}$ released to the atmosphere that might contribute to global warming as a greenhouse gas. The International Energy Agency (2015) estimated that oil produced by using anthropogenic $\mathrm{CO}_{2}$ in the $\mathrm{CO}_{2}$-EOR process averages about 63 percent less carbon emitted than oil produced through traditional methods (National Petroleum Council, 2019). 
Previous global and national assessments of recoverable oil resources and associated $\mathrm{CO}_{2}$ retention in oil reservoirs have utilized various assessment methods and economic constraints and have produced a wide range of results. Advanced Resources International (2021) reported that oil produced as a result of $\mathrm{CO}_{2}$-EOR in the conterminous United States amounted to approximately 300,000 barrels of oil per day in 2019. Oil production related to $\mathrm{CO}_{2}$-EOR will likely increase in the United States because the Bipartisan Budget Act of 2018 (Public Law 115-123) aims to increase oil production related to $\mathrm{CO}_{2}$-EOR by increasing tax credits that operators receive for injecting and sequestering anthropogenic $\mathrm{CO}_{2}$.

The objective of this circular is to present the results of a USGS assessment of (1) the volumes of oil that could be technically recoverable by applying the $\mathrm{CO}_{2}$-EOR process to suitable oil reservoirs underlying onshore and State waters areas of the conterminous United States ${ }^{1}$ and (2) the mass of $\mathrm{CO}_{2}$ that could be stored (retained) in assessed petroleum reservoirs after the completion of the $\mathrm{CO}_{2}$-EOR process. The assessment results for each assessed play, province, and region and the national results are reported in millions of barrels (MMbbl) of recoverable oil, and the volumes of $\mathrm{CO}_{2}$ retained are reported in millions of metric tons (Mt). The methodology used for the assessment (Warwick and others, 2019) follows the current practice in industry to maximize oil production rather than $\mathrm{CO}_{2}$ retention because, in the general absence of regulations or economic incentives, the industry practice is to reduce the cost of $\mathrm{CO}_{2}$ purchased for EOR (Jahangiri and Zhang, 2010). This assessment does not include economic, logistical, legal, environmental, or political constraints, such as the availability of pipelines for $\mathrm{CO}_{2}$ supply, surface ownership, or infrastructure for separating $\mathrm{CO}_{2}$ from the produced hydrocarbons. For a general review of the $\mathrm{CO}_{2}$-EOR process, please refer to Verma (2015).

Two other products are being published in conjunction with this assessment results circular, and the reader may refer to them for additional information. The companion data release (Warwick and others, 2022a) contains (1) a generic list of assessed reservoirs in each play with primary reservoir lithology (summarized as clastic or carbonate), estimated reservoir mean original oil in place $(O O I P)$ values, and estimated reservoir oil recovery factors and $\mathrm{CO}_{2}$ retention values related to the $\mathrm{CO}_{2}$-EOR process and (2) pairwise statistical correlation $^{2}$ matrices specifying geological and methodological dependencies among plays, provinces, and regions that are needed for aggregation of results outside of the means. The related fact sheet summarizes the final results of this assessment (Warwick and others, 2022b).

\footnotetext{
'State waters are defined in the "Glossary."

${ }^{2}$ The terms "statistical correlation" or "correlation" used in this report should not be confused with the "correlations" that might be used in stratigraphic, structural, or especially reservoir engineering contexts.
}

\section{National Subdivisions}

The oil reservoirs evaluated in this assessment are organized by previously defined USGS plays, petroleum provinces (all assessed provinces were sedimentary basins), and regions (U.S. Geological Survey National Oil and Gas Resource Assessment Team, 1995; Beeman and others, 1996; Carolus and others, 2017; Warwick and others, 2019). This arrangement was chosen because the primary databases used for the initial national oil and natural gas resource assessment were organized by USGS plays, provinces, and regions. See the section of this circular below on "Data Sources" for more details on the various datasets used in the assessment.

The U.S. Geological Survey National Oil and Gas Resource Assessment Team (1995, p. 6) defined a play as "a set of known or postulated oil and (or) gas accumulations sharing similar geologic, geographic, and temporal properties, such as source rock, migration patterns, timing, trapping mechanism, and hydrocarbon type." Confirmed plays are plays where one or more accumulations of minimum size ( 1 million barrels of oil or 6 billion cubic feet of gas) have been discovered in the play (U.S. Geological Survey National Oil and Gas Resource Assessment Team, 1995).

The U.S. Geological Survey National Oil and Gas Resource Assessment Team (1995) aggregated the U.S. oil and gas resources in plays by province and region. For that study, the United States was divided into 8 regions and 71 provinces. The regions are geographic and provide broad geologic groupings of provinces. The provinces are based on natural geologic entities and may include a single dominant structural element or several contiguous elements. The provinces are named for structural or geographic features within their boundaries (U.S. Geological Survey National Oil and Gas Resource Assessment Team, 1995).

\section{Data Sources}

The Comprehensive Resource Database (CRD) was developed to identify candidate reservoirs for $\mathrm{CO}_{2}$-EOR and to provide a basis for the assessment of the technically recoverable hydrocarbons from conventional oil reservoirs (Carolus and others, 2017; Warwick and others, 2019). The data within the CRD either are not available or have limited availability owing to restrictions associated with the proprietary databases used to build the CRD. Contact the Director, Energy Resources Program, U.S. Geological Survey, Reston, Va., for more information. Data in the CRD include location information for fields and reservoirs along with reservoir fluid properties and production data from the proprietary database by Nehring Associates (2012), "The Significant Oil and Gas Fields of the United States Database," and proprietary production and drilling data by well from IHS Inc. (2012). The 
reservoirs in the CRD were organized by the geologic plays and petroleum provinces as described above.

The commercial databases provide information on the geologic characteristics of reservoirs, formations, and fields; the reservoir properties; and some production data; however, they differ in the type of data they report. The Nehring Associates (2012) database reports production by individual reservoir or field, whereas the IHS Inc. $(2011,2012)$ databases report production by individual well or producing entity such as a lease. Carolus and others (2017) described the parameters from the Nehring Associates and IHS databases that were used to create the CRD. The IHS data were used to augment the production data from the Nehring database for years 2011 and 2012. Well and lease production data from IHS were aggregated to the field level, and, for fields where the two databases matched, the extended production data for IHS were allocated to the reservoirs in the Nehring database according to each reservoir's historical production. Several publicly available reservoir engineering databases were used as secondary sources to complement or verify the estimates and ranges of reservoir values found in the CRD and include those developed by the National Petroleum Council (1984b) and those compiled by (1) the Appalachian Oil and Natural Gas Research Consortium (1996), (2) the Midwest Regional Carbon Sequestration Partnership (Riley and others, 2010), and (3) the Midwest Geological Sequestration Consortium (2012).

The CRD contains the location, key petrophysical properties, production, and well counts from the Nehring Associates (2012) database for approximately 26,000 significant oil and gas reservoirs in the United States; a significant reservoir has more than 0.5 million barrels of oil equivalent of reserves and cumulative production. To supplement the Nehring Associates (2012) database, values of some properties were estimated by using various analogs and algorithms that primarily relied on play and province averages. ${ }^{3}$ The reservoirs in the combined datasets were screened for their suitability for miscible or immiscible $\mathrm{CO}_{2}$-EOR. More than 3,500 oil reservoirs were identified as candidates for miscible $\mathrm{CO}_{2}$-EOR and are included in this assessment. Reservoirs identified as candidates for the immiscible $\mathrm{CO}_{2}$-EOR recovery process were not assessed because there are few of them (approximately 250), and their combined OOIP is insignificant compared to that of the miscible reservoirs (Warwick and others, 2019). For details on the development of the CRD and reservoir screening criteria, see Carolus and others (2017). The companion data release (Warwick and others, 2022a) for this circular contains a nonproprietary generic list of assessed reservoirs in each play along with primary reservoir lithology (summarized as clastic or carbonate) and an estimated mean $O O I P$ value for each reservoir.

\footnotetext{
${ }^{3}$ As described in Carolus and others (2017), play averages are used for 28 percent of reservoir attribute records for over 22,000 reservoirs. Less than 11 percent of the oil resource uses a play average, 1.2 percent uses a province average, and 0.2 percent uses a region average. Freeman and Attanasi (2015) described the properties of most reservoirs for which data are in the CRD and provided ranges of empirical and default values of the oil reservoir characteristics within a play and across plays.
}

\section{Assessment Process}

To implement the methodology (Warwick and others, 2019) used for this assessment process, assessment geologists from the USGS reviewed the literature, the CRD, and other available reservoir databases for each province and play in the United States. The primary purpose of the review was to compare the values in the CRD with the values reported in the literature and by the National Petroleum Council (1984b). The geologic and reservoir input data described in appendixes 1 and 3 of Warwick and others (2019) were verified by an assessment geologist, presented to an assessment panel, and agreed upon by unanimous group consensus. If significant discrepancies were found, the new values were entered into a modified version of the proprietary CRD. Completion of the assessment required the geologist to estimate correlations for aggregating the resources by play, petroleum province, region, and the onshore and State waters areas of the conterminous United States (Warwick and others, 2019). The aggregation process for the assessment results is described in Warwick and others (2019) and summarized below in the "Aggregation Dependencies and General Guidelines" section of this report.

\section{Assessment Assumptions and Constraints}

As discussed in Warwick and others (2019), the basic requirement for $\mathrm{CO}_{2}$-EOR is to have a reliable source of $\mathrm{CO}_{2}$, which could be either natural (for example, $\mathrm{CO}_{2}$-rich natural gas reservoirs) or anthropogenic (for example, $\mathrm{CO}_{2}$ captured at industrial facilities). The methodology (Warwick and others, 2019) used for this assessment relies on the assumption that an adequate source of $\mathrm{CO}_{2}$ that is more than 90-percent pure will be available from either natural or anthropogenic sources for $\mathrm{CO}_{2}$-EOR projects. Another assumption in the methodology is that the $\mathrm{CO}_{2}$ retained in the reservoir after cessation of the $\mathrm{CO}_{2}$-EOR process will not be removed for reuse in other $\mathrm{CO}_{2}$-EOR projects.

The fundamentals of applying the $\mathrm{CO}_{2}$-EOR process in conventional reservoirs are well understood (Verma, 2015). Recent advancements have been made (1) by applying the $\mathrm{CO}_{2}$-EOR process in residual oil zones (ROZs; Hill and others, 2013) and continuous oil accumulations such as tight oil shale (Jin and others, 2017; Kuuskraa and others, 2020) and (2) by using advanced "next generation" or "net carbon negative oil" $\mathrm{CO}_{2}$-EOR technologies. These advancements may increase the potential for technically recoverable hydrocarbon volumes along with maximized $\mathrm{CO}_{2}$ storage (Kuuskraa and others, 2011; NuñezLópez and others, 2019). Uses of ROZs and continuous reservoirs and advanced technologies are typically not part of present oil-field $\mathrm{CO}_{2}$-EOR production practices and are not addressed in this assessment. Specifically, the recovery factors used for this assessment are based on current proven $\mathrm{CO}_{2}$-EOR practices.

The technology to inject $\mathrm{CO}_{2}$ for enhanced gas and condensate recovery exists (Mamora and Seo, 2002; Oldenburg and Benson, 2002; van der Meer and others, 2005); however, there are no known reports of commercial fieldwide applications of 
National Assessment of $\mathrm{CO}_{2}$-EOR and Associated $\mathrm{CO}_{2}$ Retention Resources-Results

the enhanced gas recovery process, likely because of economic constraints, such as the cost of gas separation facilities and the availability and cost of $\mathrm{CO}_{2}$ (Warwick and others, 2019). As there are no current enhanced gas recovery projects operating, they are not included in this assessment (Warwick and others, 2019).

This national assessment is a geology- and petroleum engineering-based examination of more than 3,500 conventional oil reservoirs in the onshore and State waters areas of the conterminous United States. Reservoirs that had initiated any form of EOR were excluded because additional reservoir-specific data are required to model the remaining oil recovery factors with the $\mathrm{CO}_{2}$ Prophet software used in the assessment methodology (Dobitz and Prieditis, 1994; Attanasi, 2017; Warwick and others, 2019). Potential $\mathrm{CO}_{2}$-miscible reservoirs in Alaska were not evaluated because there were only a few ( 25 reservoirs), and they were primarily developed with horizontal and deviated wells, thus making recovery factors difficult to model with $\mathrm{CO}_{2}$ Prophet. Hawaii was considered unlikely to have oil resources because of its unfavorable petroleum geology.

\section{Resource Calculations}

Warwick and others (2019) described the various steps used in the $\mathrm{CO}_{2}$-EOR screening process for oil reservoirs that have undergone primary or secondary oil production. For any reservoir found to be amenable to $\mathrm{CO}_{2}$-EOR, the incremental oil volume produced by enhanced oil recovery $\left(E O R_{v}\right)$ is determined by multiplying the original oil in place $(O O I P)$ by the incremental oil recovery factor $(R F)$ as follows:

$$
E O R_{v}=O O I P \times R F
$$

To make a probabilistic estimate of technically recoverable hydrocarbon volume, estimates of the $O O I P$ and $R F$ values, as well as their uncertainty, are needed for each reservoir (Warwick and others, 2019). The OOIP and $R F$ values are made into continuous random variables with a defined mean and spread by the methods described in Warwick and others (2019). Once the OOIP and $R F$ distributions are obtained, they are sampled 10,000 times and multiplied together in a Monte Carlo simulation to generate a numerical range of estimates for the $\mathrm{CO}_{2}$-EOR production volume and associated $\mathrm{CO}_{2}$ retention of each reservoir within the conterminous United States that has passed the screening criteria (Warwick and others, 2019). Summary statistics, including the mean, $\mathrm{P}_{5}, \mathrm{P}_{50}$, and $\mathrm{P}_{95},{ }^{4}$ or any other percentile, can be calculated directly from this distribution (Warwick and others, 2019).

\footnotetext{
${ }^{4} \mathrm{P}_{5}, \mathrm{P}_{50}$, and $\mathrm{P}_{95}$ are probability percentiles and represent the 5-, 50-, and 95-percent probabilities, respectively, that the true storage resource, either recoverable oil or stored (retained) $\mathrm{CO}_{2}$, is less than or equal to the value shown. The terminology used in this report differs from that used by the petroleum industry (which lists the percentiles in reverse order) and follows standard statistical practice (for example, Everitt and Skrondal, 2010), where percentiles, or fractiles, represent the value of a variable below which a certain proportion of observations falls. The percentiles were calculated by using the aggregation method described in U.S. Geological Survey Geologic Carbon Dioxide Storage Resources Assessment Team (2013b) and in Blondes, Schuenemeyer, and others (2013).
}

The volume of $\mathrm{CO}_{2}$ retained in the reservoir is determined by multiple factors acting generally in combinations that vary according to the geology of the reservoir and the implementation and type of recovery process (Olea, 2015; Warwick and others, 2019). In this assessment, $\mathrm{CO}_{2}$ retention is the percentage of injected $\mathrm{CO}_{2}$, measured in thousands of standard cubic feet (Mscf), that remains in the subsurface as a result of the $\mathrm{CO}_{2}$ flooding. ${ }^{5}$ The volume of $\mathrm{CO}_{2}$ retained in each reservoir was converted to mass of $\mathrm{CO}_{2}$ measured in millions of metric tons (Mt) (Warwick and others, 2019) to allow ease of comparison to other $\mathrm{CO}_{2}$ storage assessment results such as those reported by the U.S. Geological Survey Geologic Carbon Dioxide Storage Resources Assessment Team (2013b). The percentage of reservoir $\mathrm{CO}_{2}$ retention is calculated as follows:

$$
\mathrm{CO}_{2} \text { retention }=100 \times \frac{\mathrm{CO}_{2} \text { remaining at subsurface }}{\text { cumulative } \mathrm{CO}_{2} \text { injected }}
$$

where the quantity of cumulative injected $\mathrm{CO}_{2}$ is equivalent to the $\mathrm{CO}_{2}$ that is purchased rather than the gross injected volume, which includes recycled $\mathrm{CO}_{2}$.

Additional details on each step in this assessment process are described in Warwick and others (2019). Please refer to the data release (Warwick and others, 2022a) supporting this circular for a list of assessed reservoirs and their estimated mean $O O I P$ values, $R F$ values, and $\mathrm{CO}_{2}$ retention values related to the $\mathrm{CO}_{2}$-EOR process.

\section{Aggregation Dependencies and General Guidelines}

As described in Warwick and others (2019), the probability distribution at the play level and beyond cannot be determined without taking dependencies, or correlations, between reservoirs into account. These dependencies are introduced as part of the aggregation process and have a strong effect on the uncertainty of the summed distributions. In general, for distributions with a positive skew (which are typical for geologic data), as the correlations increase, the distributions for the aggregated resources have lower medians and higher dispersions (Blondes, Schuenemeyer, and others, 2013). For this assessment, a correlation matrix was generated with values that represent the dependencies between reservoirs according to expert estimates elicited from the assessment geologists (Meyer and Booker, 2001; Warwick and others, 2019). The matrix was used to induce a rank correlation structure between the reservoir probability distributions as they were combined to form an aggregate sum (Kaufman and others, 2018). An example aggregation for the Horseshoe Atoll play is shown in Warwick and others (2019, app. 3).

\footnotetext{
${ }^{5}$ The net $\mathrm{CO}_{2}$ utilization (gross $\mathrm{CO}_{2}$ injection minus the produced $\mathrm{CO}_{2}$ volume) for each reservoir in the play is estimated by using a net $\mathrm{CO}_{2}$ utilization factor per stock tank barrel of oil recovered (at surface conditions) multiplied by the recoverable oil to generate the volume of $\mathrm{CO}_{2}$ (at surface conditions) that will be retained for each value of OOIP simulated by $\mathrm{CO}_{2}$ Prophet (Warwick and others, 2019).
} 
Table 1. Ranges of values used for correlation coefficients to obtain play, province, region, and national distributions for the conterminous United States.

\begin{tabular}{lr}
\hline \multicolumn{1}{c}{ Distribution area } & Range \\
\hline Play distributions from reservoirs & 0.62 to 0.86 \\
Province distributions from plays & 0.50 to 0.70 \\
Region distributions from provinces & 0.35 to 0.55 \\
National distributions from regions & 0.20 to 0.40 \\
\hline
\end{tabular}

The correlation coefficients used in this assessment for reservoirs, plays, provinces, and regions are described in the sections below. The data release by Warwick and others (2022a) contains the pairwise correlation matrices that specify the dependencies among plays, provinces, and regions that were used for the aggregation of results outside of the means.

The sections below describe the applied ranges of correlation values among reservoirs, plays, provinces, and regions. Table 1 summarizes the ranges that were used.

\section{Reservoirs Within a Play}

Statistical correlation values for reservoirs within a play were automatically assigned on the basis of the source of the values for porosity $(\varnothing)$ and initial or original oil saturation (SOI) (Carolus and others, 2017; Warwick and others, 2019). As described in Carolus and others (2017), the source of the data for each estimated reservoir property is designated by a "CRD shadow code." A shadow code of 1 indicates that the data values were obtained from the Nehring Associates (2012) reservoir database or verified from other reservoir-specific data sources; a shadow code of 2 indicates that the data value is a play average; and a shadow code of 3 indicates that the data value is a province average. Table 2 describes the assigned pairwise correlation values based on the reservoir $\varnothing$ and $S O I$ shadow codes.

\section{Plays Within a Province}

Statistical correlations among plays within a province were determined by the following criteria. Each assessment geologist evaluated the plays in an assigned province to determine if the plays correlated at the "high," "medium," or "low" level. Play correlation defaulted to the medium level unless there was a geologic reason the plays within a province were or were not correlated. Play properties that were considered include the geologic controls on porosity $(\varnothing)$, original oil saturation $(S O I)$ as a proxy for petroleum charge, permeability $(k)$ as a proxy for the Dykstra-Parsons coefficient $(V D P)$, and diagenesis (the degree of lithification and cementation of the reservoir rock).
Table 2. Values used for the correlation of reservoirs within a play based on pairs of reservoir shadow codes for porosity ( $\varnothing$ ) and initial oil saturation ( $S O /$ ) reported in the Comprehensive Resource Database (CRD) of Carolus and others (2017).

[Possible reservoir shadow code values are 1, 2, or 3 individually, and pairwise possible values for $\emptyset, S O I$ are $(1,1),(1,2$ or 3$),(2$ or 3,1$)$, or $(2$ or 3 , 2 or 3)]

\begin{tabular}{|c|c|c|c|}
\hline \multirow[b]{2}{*}{0, sol } & \multicolumn{3}{|c|}{ Reservoir shadow code } \\
\hline & 1,1 & $\begin{array}{c}1,2 \text { or } 3 ; \\
2 \text { or } 3,1\end{array}$ & $\begin{array}{l}2 \text { or } 3 \\
2 \text { or } 3\end{array}$ \\
\hline 1,1 & 0.66 & 0.7 & 0.74 \\
\hline $\begin{array}{l}1,2 \text { or } 3 ; \\
2 \text { or } 3,1\end{array}$ & & 0.78 & 0.82 \\
\hline $\begin{array}{l}2 \text { or } 3, \\
2 \text { or } 3\end{array}$ & & & 0.86 \\
\hline
\end{tabular}

The geologic controls also included depositional environment, hydrocarbon trapping style, source rocks, and diagenetic history among other factors, such as the degree of reservoir fracturing and structural deformation. A correlation matrix was generated with values that represent the dependencies between plays according to expert estimates elicited from the assessment geologists. The correlation matrix values (table 3) were determined by group consensus. More details about each correlation category are provided below.

High: All plays within the province are very similar; they are geologic twins with similar reservoir primary lithologies and geologic characteristics; or one of the shadow codes for porosity or $S O I$ is a value of 3 , which is the province average.

Medium: Medium was used as the default correlation value. The plays within the province are not similar. For example, the reservoirs within the plays may have mixed lithologies or differing diagenetic histories but may share other geologic characteristics or reservoir properties.

Low: The plays within the province are very dissimilar; they have very different geologic characteristics, including reservoir properties and diagenetic histories.

\section{Correlations Among Provinces Within a Region and Among Regions}

Correlations among provinces within a region and among regions within the conterminous United States were determined by using the same general criteria that were used for plays within a province, as described above (table 3). No CRD reservoir shadow codes were considered in the correlation process at this level, as values existed for all reservoir properties so regional- and national-level averages did not have to be supplied. 
Table 3. Correlation values used for the aggregation of plays within a province, provinces within a region, and regions within the conterminous United States (CONUS).

\begin{tabular}{|c|c|c|c|}
\hline \multirow[b]{2}{*}{$\begin{array}{l}\text { Correlation } \\
\text { levels }\end{array}$} & \multicolumn{3}{|c|}{ Correlation values } \\
\hline & $\begin{array}{l}\text { Plays within } \\
\text { a province }\end{array}$ & $\begin{array}{l}\text { Provinces } \\
\text { within a } \\
\text { region }\end{array}$ & $\begin{array}{l}\text { Regions of the } \\
\text { CONUS }\end{array}$ \\
\hline High & 0.7 & 0.55 & 0.4 \\
\hline Medium & 0.6 & 0.45 & 0.3 \\
\hline Low & 0.5 & 0.35 & 0.2 \\
\hline
\end{tabular}

\section{Results of the Assessment of Carbon Dioxide Enhanced Oil Recovery and Associated Carbon Dioxide Retention Resources}

The assessment results provide an estimate of the volume of oil that could be produced by applying the $\mathrm{CO}_{2}$-EOR process in amenable reservoirs underlying onshore and State waters areas of the conterminous United States. They also provide an estimate of the potential mass of associated subsurface $\mathrm{CO}_{2}$ retention. The results are summarized below and illustrated in tables 4, 5, and 6 and figures 1, 2, 3, 4, 5, and 6 . Table 4 contains the national results, whereas table 5 contains the assessment results aggregated by region and province. Table 6 (at end of report) presents the results by province and individual play. All results are rounded to two significant figures because too many digits imply a higher level of precision than is justified by the original data used for the assessment. Mean values sum to totals but are reported to only two significant figures.

Following the procedures described in Warwick and others (2019), the assessment team estimated that in existing reservoirs underlying onshore and State waters areas of the conterminous United States, the technically recoverable oil resulting from the application of the $\mathrm{CO}_{2}$-EOR process ranges from approximately $25,000 \mathrm{MMbbl}$ at the $\mathrm{P}_{5}$ percentile to as much as $32,000 \mathrm{MMbbl}$ at the $\mathrm{P}_{95}$ percentile, with a mean of 29,000 MMbbl. The associated $\mathrm{CO}_{2}$ retention was estimated to range from approximately $7,400 \mathrm{Mt}$ at the $\mathrm{P}_{5}$ percentile to as much as $9,500 \mathrm{Mt}$ at the $\mathrm{P}_{95}$ percentile, with a mean of $8,400 \mathrm{Mt}$ (table 4). Figure 1 illustrates the results obtained from a Monte Carlo simulation in which each input distribution was sampled 10,000 times for the national technically
Table 4. Total estimated volume of oil that could be produced with carbon dioxide enhanced oil recovery $\left(\mathrm{CO}_{2}-\mathrm{EOR}\right)$ and total mass of associated carbon dioxide $\left(\mathrm{CO}_{2}\right)$ that could be stored (retained) in existing reservoirs underlying onshore and State waters areas of the conterminous United States.

[Estimates of volumes of oil that could be produced with $\mathrm{CO}_{2}$-EOR are in millions of petroleum barrels (MMbbl), and estimates of the mass of associated $\mathrm{CO}_{2}$ that could be stored (retained) are in millions of metric tons (Mt). $\mathrm{P}_{5}, \mathrm{P}_{50}$, and $\mathrm{P}_{95}$ are probability percentiles and represent the 5-, 50-, and 95-percent probabilities, respectively, that the true resource is less than or equal to the value shown. The terminology used in this report differs from that used by the petroleum industry and follows standard statistical practice (for example, Everitt and Skrondal, 2010), where percentiles, or fractiles, represent the value of a variable below which a certain proportion of observations falls. The percentiles were calculated by using the aggregation method described in U.S. Geological Survey Geologic Carbon Dioxide Storage Resources Assessment Team (2013b) and in Blondes, Schuenemeyer, and others (2013). Percentile values do not sum to totals because the aggregation procedure used partial dependencies between assessment units. Values are reported to only two significant figures]

\begin{tabular}{ccccc}
\hline Resource type & $\mathbf{P}_{5}$ & $\mathbf{P}_{50}$ & $\mathbf{P}_{95}$ & Mean \\
\hline Oil produced during & 25,000 & 29,000 & 32,000 & 29,000 \\
$\mathrm{CO}_{2}$-EOR (MMbbl) & & & & \\
$\mathrm{CO}_{2}$ retention (Mt) & 7,400 & 8,400 & 9,500 & 8,400 \\
\hline
\end{tabular}

recoverable volumes of oil and the total mass of subsurface $\mathrm{CO}_{2}$ retention associated with the $\mathrm{CO}_{2}$-EOR process. Similar simulations were run to generate the assessment results presented in tables 4, 5, and 6 and figures 2, 3, 4, 5, and 6 .

\section{Carbon Dioxide Enhanced Oil Recovery}

The mean technically recoverable volume of oil that could be produced from the application of $\mathrm{CO}_{2}$-EOR in existing reservoirs underlying onshore and State waters areas of the conterminous United States is equivalent to approximately $29,000 \mathrm{MMbbl}$ $\left(\mathrm{P}_{5}=25,000 \mathrm{MMbbl}\right.$, and $\left.\mathrm{P}_{95}=32,000 \mathrm{MMbbl}\right)$ (table 4). The $\mathrm{CO}_{2}$-EOR assessment regions that are estimated to contain the highest amounts of oil producible by the application of $\mathrm{CO}_{2}-\mathrm{EOR}$ include West Texas and Eastern New Mexico, Gulf Coast, Midcontinent, and Rocky Mountains and Northern Great Plains (figs. $2 A, 3 A, 4 A$ ). Six provinces that are estimated to contain mean amounts greater than $1,000 \mathrm{MMbbl}$ of technically recoverable volumes of oil are listed in decreasing order: (1) Permian Basin, 11,000 MMbbl; (2) Western Gulf, 3,500 MMbbl; (3) East Texas Basin and Louisiana-Mississippi Salt Basins, 1,800 MMbbl; (4) Williston Basin, 1,300 MMbbl; (5) Bend Arch-Fort Worth Basin, 1,300 MMbbl; and (6) Anadarko Basin, 1,200 MMbbl (table 5; figs. 5A, 6A). 
$\boldsymbol{A}$

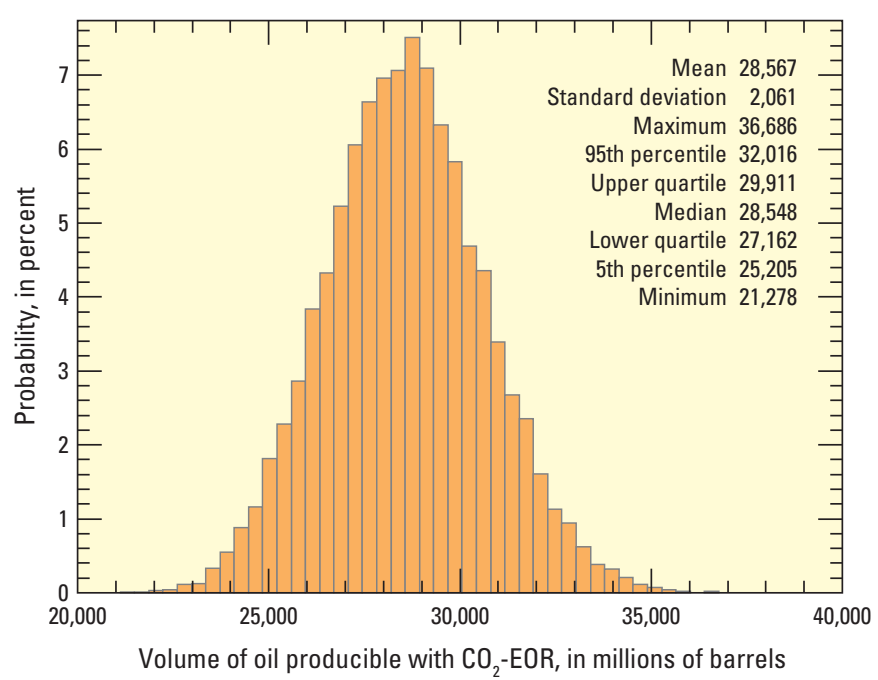

C

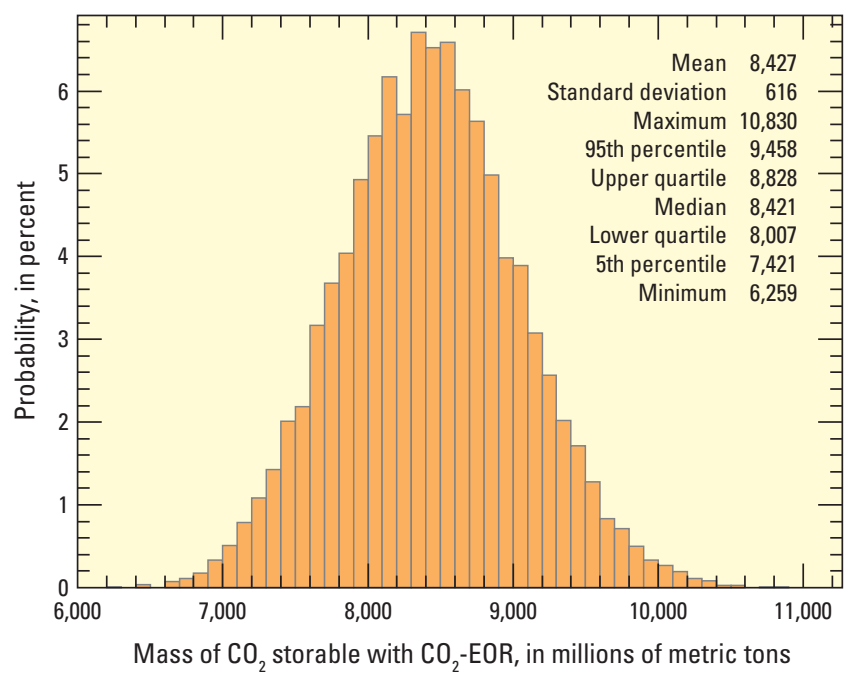

$B$

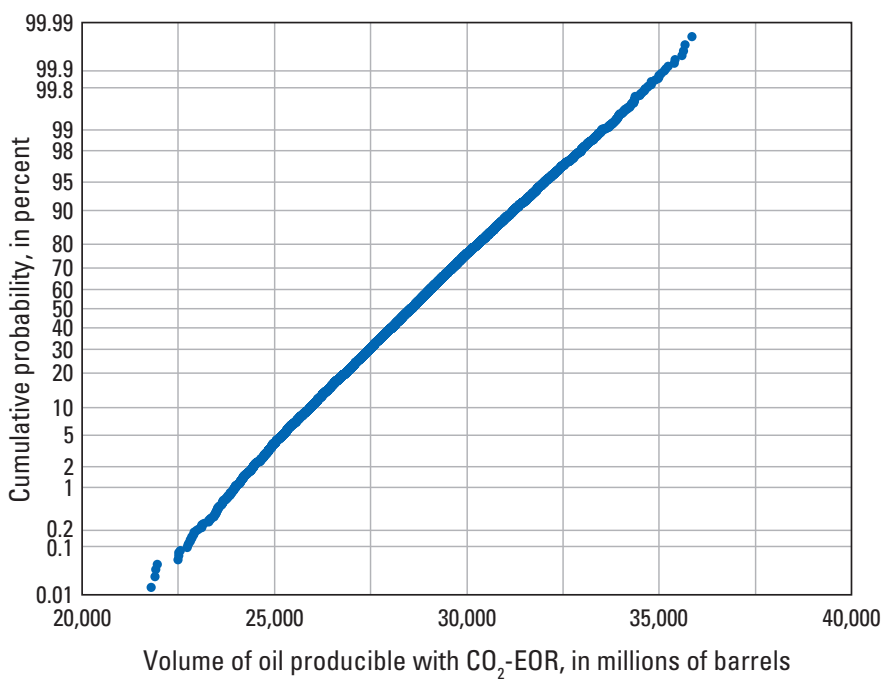

D

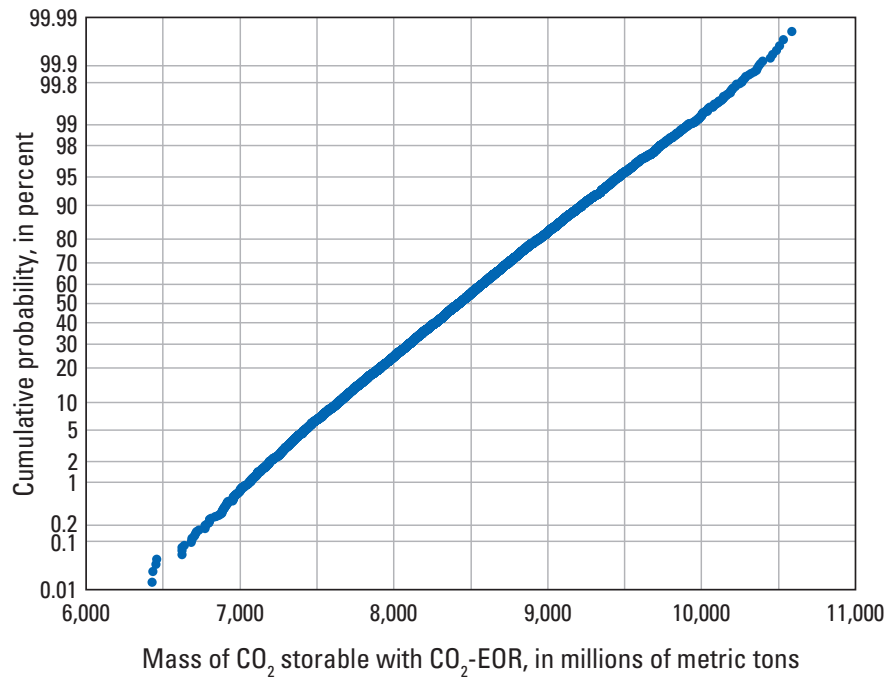

Figure 1. Graphs showing probabilities for estimates of national technically recoverable volumes of oil that could be produced with carbon dioxide enhanced oil recovery $\left(\mathrm{CO}_{2}-\mathrm{EOR}\right)$ and of the national total mass of associated subsurface $\mathrm{CO}_{2}$ that could be stored (retained) with the application of $\mathrm{CO}_{2}$-EOR. The graphs show the results obtained from a Monte Carlo simulation in which each input distribution was sampled 10,000 times. The results incorporate probabilistic aggregation and different assumptions of correlation between assessed reservoirs that underlie onshore and State waters areas of the conterminous United States. The data table values in parts $A$ and $C$ are not rounded to illustrate the full range of the Monte Carlo simulation results. See Warwick and others (2019) for more details about the assessment process. $A$, Histogram of probabilities for estimates of oil volumes that could be produced. $B$, Point graph of the cumulative distribution of probabilities for estimates of oil volumes that could be produced. $C$, Histogram of probabilities for estimates of the mass of $\mathrm{CO}_{2}$ that could be stored (retained). $D$, Point graph of the cumulative distribution of probabilities for estimates of the mass of $\mathrm{CO}_{2}$ that could be stored. 
Table 5. Estimated volume of oil that could be produced with carbon dioxide enhanced oil recovery (CO ${ }_{2}$-EOR) and estimated mass of associated carbon dioxide $\left(\mathrm{CO}_{2}\right)$ that could be stored (retained) in existing reservoirs underlying onshore and State waters areas of the conterminous United States, aggregated by region and province.

[Estimates of volumes of oil that could be produced with $\mathrm{CO}_{2}$-EOR are in millions of petroleum barrels (MMbbl), and estimates of the mass of associated $\mathrm{CO}_{2}$ that could be stored (retained) are in millions of metric tons (Mt). $\mathrm{P}_{5}, \mathrm{P}_{50}$, and $\mathrm{P}_{95}$ are probability percentiles and represent the 5-, 50-, and 95-percent probabilities, respectively, that the true resource is less than or equal to the value shown. The terminology used in this report differs from that used by the petroleum industry and follows standard statistical practice (for example, Everitt and Skrondal, 2010), where percentiles, or fractiles, represent the value of a variable below which a certain proportion of observations falls. The percentiles were calculated by using the aggregation method described in U.S. Geological Survey Geologic Carbon Dioxide Storage Resources Assessment Team (2013b) and in Blondes, Schuenemeyer, and others (2013). Percentile values do not sum to totals because the aggregation procedure used partial dependencies between assessment units. The $\mathrm{P}_{50}$ (median) values may be less than mean values because most output distributions are right skewed. Values are reported to only two significant figures, and mean entries may not sum to totals because of rounding. A four-digit code identifies the USGS-specific province. Components of this assessment unit code are explained in the "Glossary." Resources in Alaska (Region 1), Hawaii, and federally owned offshore areas were not assessed]

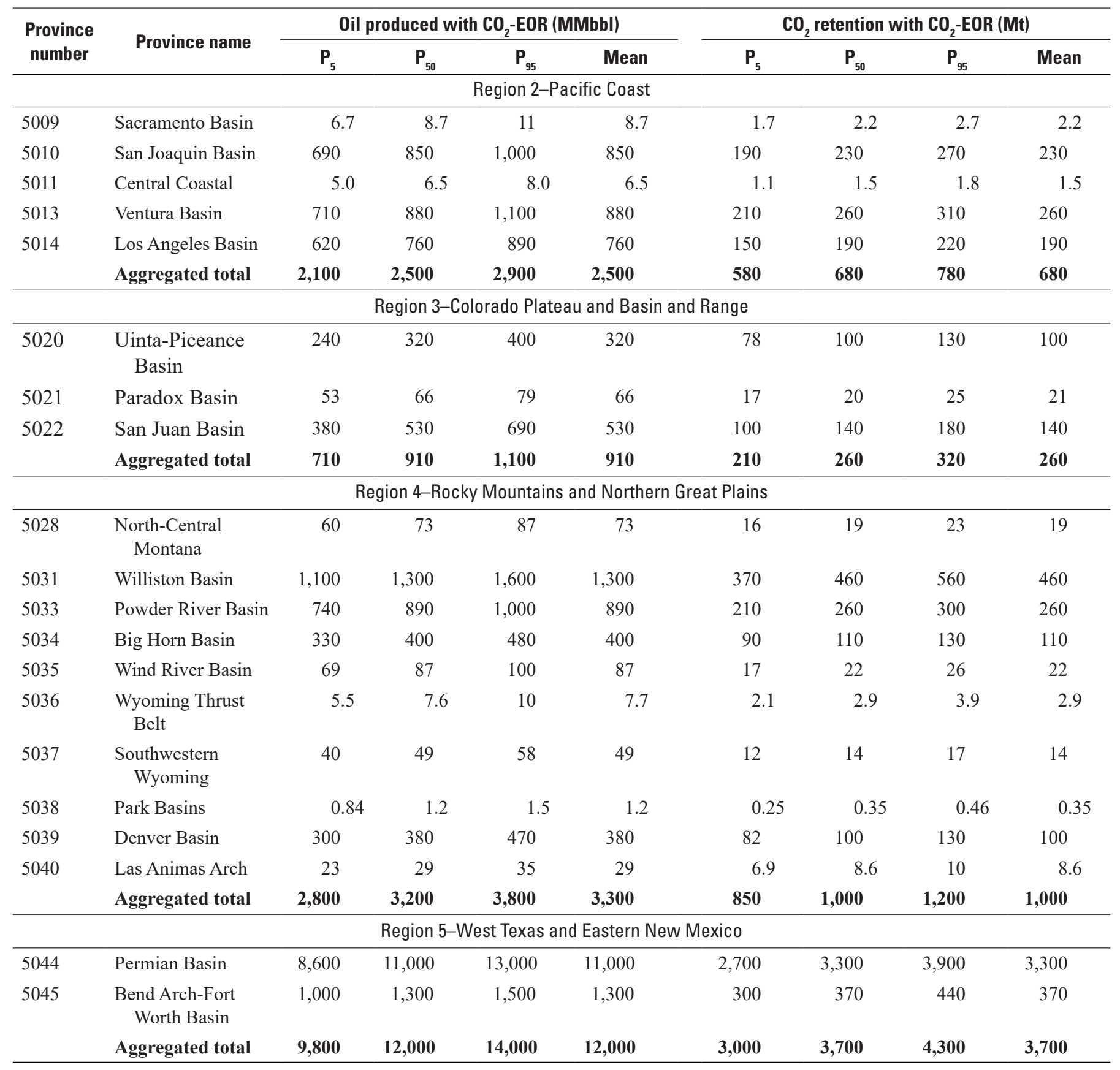


Table 5. Estimated volume of oil that could be produced with carbon dioxide enhanced oil recovery $\left(\mathrm{CO}_{2}\right.$-EOR) and estimated mass of associated carbon dioxide $\left(\mathrm{CO}_{2}\right)$ that could be stored (retained) in existing reservoirs underlying onshore and State waters areas of the conterminous United States, aggregated by region and province.-Continued

[Estimates of volumes of oil that could be produced with $\mathrm{CO}_{2}$-EOR are in millions of petroleum barrels (MMbbl), and estimates of the mass of associated $\mathrm{CO}_{2}$ that could be stored (retained) are in millions of metric tons (Mt). $\mathrm{P}_{5}, \mathrm{P}_{50}$, and $\mathrm{P}_{95}$ are probability percentiles and represent the 5-, 50-, and 95-percent probabilities, respectively, that the true resource is less than or equal to the value shown. The terminology used in this report differs from that used by the petroleum industry and follows standard statistical practice (for example, Everitt and Skrondal, 2010), where percentiles, or fractiles, represent the value of a variable below which a certain proportion of observations falls. The percentiles were calculated by using the aggregation method described in U.S. Geological Survey Geologic Carbon Dioxide Storage Resources Assessment Team (2013b) and in Blondes, Schuenemeyer, and others (2013). Percentile values do not sum to totals because the aggregation procedure used partial dependencies between assessment units. The $\mathrm{P}_{50}$ (median) values may be less than mean values because most output distributions are right skewed. Values are reported to only two significant figures, and mean entries may not sum to totals because of rounding. A four-digit code identifies the USGS-specific province. Components of this assessment unit code are explained in the "Glossary." Resources in Alaska (Region 1), Hawaii, and federally owned offshore areas were not assessed]

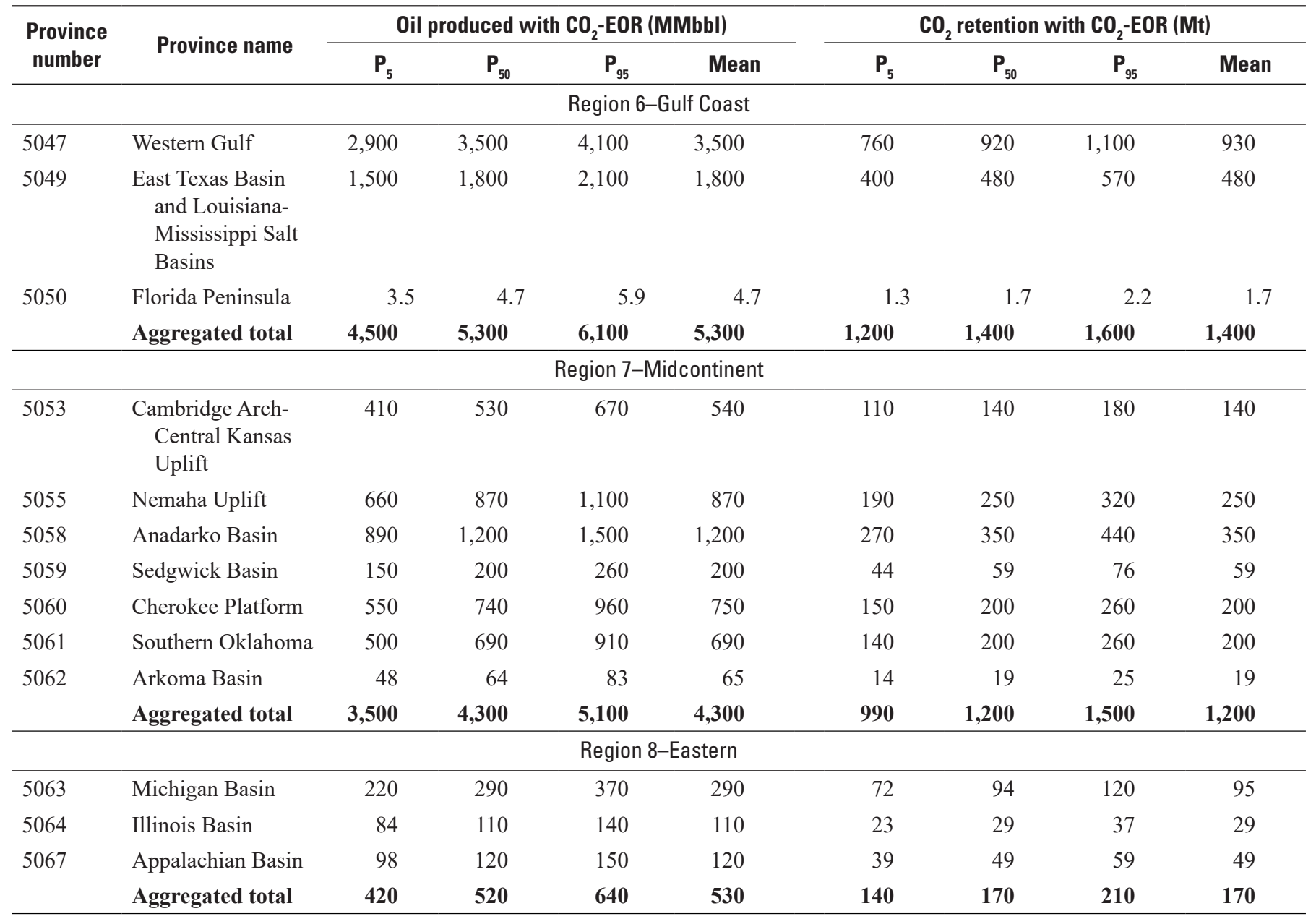




\section{A. Oil that could be produced with $\mathrm{CO}_{2}$-EOR}

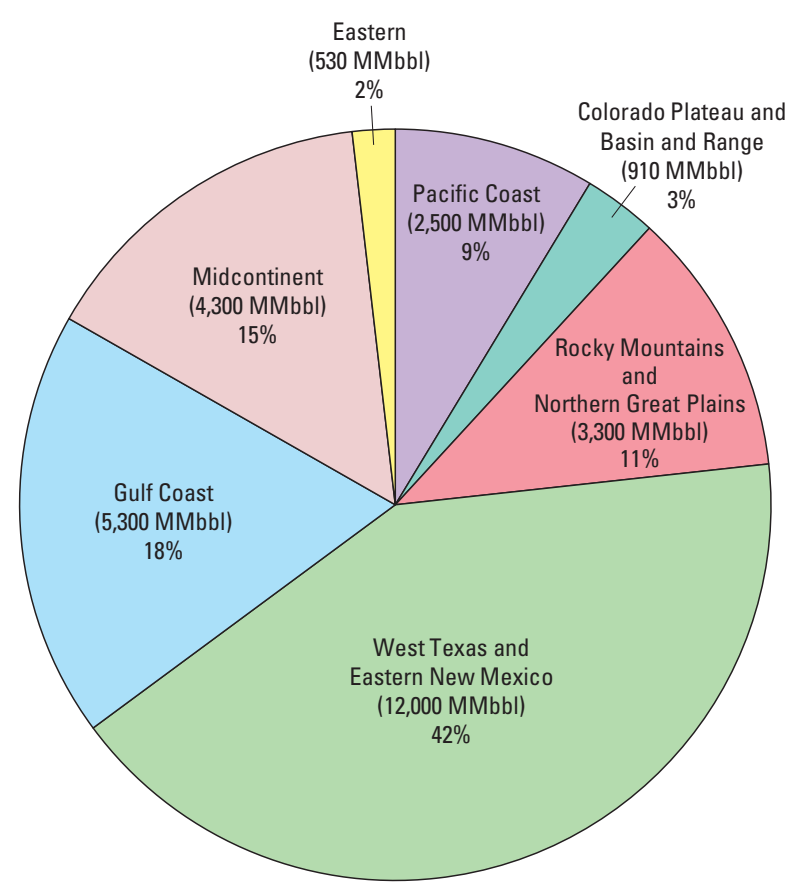

\section{B. $\mathrm{CO}_{2}$ that could be retained with $\mathrm{CO}_{2}-\mathrm{EOR}$}

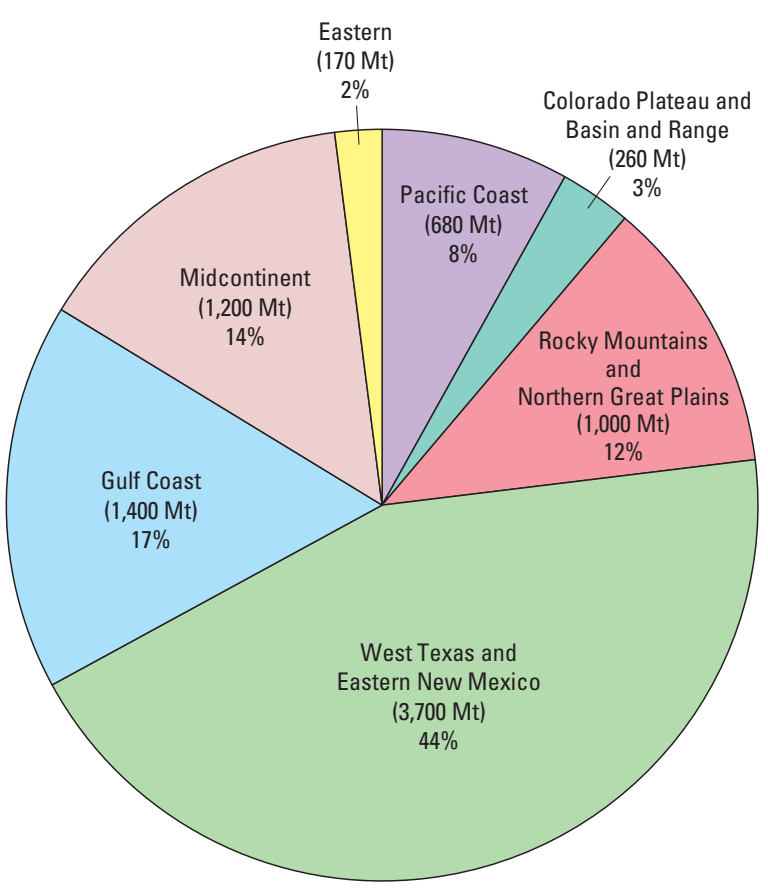

Figure 2. Pie charts showing regional mean estimates by the U.S. Geological Survey in 2020 of $(A)$ technically recoverable volumes of oil that could be produced with the application of the carbon dioxide enhanced oil recovery $\left(\mathrm{CO}_{2}\right.$-EOR) process and $(B)$ masses of associated subsurface carbon dioxide $\left(\mathrm{CO}_{2}\right)$ that could be stored (retained) with the application of the $\mathrm{CO}_{2}$-EOR process in existing reservoirs underlying onshore and State waters areas of the conterminous United States. A mean total of 29,000 million barrels (MMbbl) of oil was estimated to be producible from reservoirs amenable to the $\mathrm{CO}_{2}$-EOR process. A mean total of 8,400 million metric tons (Mt) was estimated for subsurface $\mathrm{CO}_{2}$ retention associated with the application of the $\mathrm{CO}_{2}$-EOR process. Resources in Alaska, Hawaii, and federally owned offshore areas were not assessed. Mean values sum to totals but are reported to only two significant figures. Regional outlines are shown in figure 3.

\section{Carbon Dioxide Retention Resources}

The assessed mean subsurface $\mathrm{CO}_{2}$ retention resources resulting from the application of $\mathrm{CO}_{2}$-EOR in the assessed reservoirs are equivalent to approximately $7,400 \mathrm{Mt}$ at the $\mathrm{P}_{5}$ percentile to as much as $9,500 \mathrm{Mt}$ at the $\mathrm{P}_{95}$ percentile, with a mean of $8,400 \mathrm{Mt}$ (table 4). The $\mathrm{CO}_{2}$-EOR assessment regions with the highest estimates for $\mathrm{CO}_{2}$ retention mass are the same as those with the highest estimates for oil production and include West Texas and Eastern New Mexico, Gulf Coast, Midcontinent, and Rocky Mountains and Northern Great Plains (figs. $2 B, 3 B, 4 B$ ). Six provinces that are estimated to contain mean amounts greater than $300 \mathrm{Mt}$ of $\mathrm{CO}_{2}$ retention resources are listed in decreasing order: (1) Permian Basin, 3,300 Mt; (2) Western Gulf, 930 Mt; (3) East Texas Basin and Louisiana-Mississippi Salt Basins, 480 Mt; (4) Williston Basin, $460 \mathrm{Mt}$; (5) Bend Arch-Fort Worth Basin, $370 \mathrm{Mt}$; and (6) Anadarko Basin, $350 \mathrm{Mt}$ (table 5; figs. 5B, 6B).

\section{Discussion of Results}

The numerical results of the assessment reveal various aspects about the potential volumes of oil that could be produced and the associated $\mathrm{CO}_{2}$ that may be retained in the subsurface by applying the $\mathrm{CO}_{2}$-EOR process to amenable reservoirs underlying the onshore and State waters areas of the conterminous United States. The following list explains some of the key findings of this assessment.

1. The estimated ultimate recovery of existing oil reservoirs in the United States may be increased with the use of $\mathrm{CO}_{2}$-EOR methods. The results of this assessment indicate that the application of $\mathrm{CO}_{2}$-EOR methods to oil reservoirs underlying the onshore and State waters areas of the conterminous United States can potentially add, at the mean estimate, 29,000 MMbbl to the U.S. techni- 
cally recoverable oil resource base. For context, the USGS recently estimated a mean of 3,591 MMbbl of undiscovered, technically recoverable oil resources in conventional accumulations in six conventional assessment units underlying the central North Slope of Alaska (Houseknecht and others, 2020). The U.S. Energy Information Administration (2020) reported that the 2019 annual crude oil production in the United States was 4,464.8 MMbbl.

2. Two regions - the West Texas and Eastern New Mexico region and the Gulf Coast region-contain 60 percent of the mean assessed $\mathrm{CO}_{2}$-EOR recoverable oil potential and 61 percent of the mean assessed $\mathrm{CO}_{2}$ retention. Other regions with significant resource potential include the Midcontinent region and the Rocky Mountains and Northern Great Plains region (figs. 2, 3, 4; table 5).

3. The Permian Basin is the largest single resource-rich province in the conterminous United States and contains about 38 percent of the assessed national mean $\mathrm{CO}_{2}$-EOR recoverable oil and 39 percent of the $\mathrm{CO}_{2}$ retention potential. Resource estimates for $\mathrm{CO}_{2}-\mathrm{EOR}$ in the province represent more than 3 times the recoverable oil (11,000 MMbbl, mean) and $\mathrm{CO}_{2}$ retention potential $(3,300 \mathrm{Mt}$, mean) than the next largest province, the Western Gulf (means of 3,500 MMbbl and $930 \mathrm{Mt}$, respectively) (table 5; figs. 5, 6).

4. The U.S. Environmental Protection Agency (2020) reported that the 2018 annual amount of anthropogenic $\mathrm{CO}_{2}$ emissions from all sources in the United States was estimated to be 5,424.9 Mt. The International Energy Agency (2019) suggested that carbon capture with geologic storage should contribute about 9 percent to the overall effort to prevent global temperatures from rising no more than 2 degrees Celsius $\left(2^{\circ} \mathrm{C}\right)$ from those at the beginning of the industrial revolution in the late 1800s. The results of this report indicate that in order to achieve the long-term geologic $\mathrm{CO}_{2}$ storage goals put forward by the International Energy Agency (2019), standard $\mathrm{CO}_{2}$-EOR practices that use $\mathrm{CO}_{2}$ from anthropogenic sources will need to be combined with other strategies to enhance storage of $\mathrm{CO}_{2}$ in amenable oil reservoirs. In addition, other geologic $\mathrm{CO}_{2}$ storage options may be utilized such as $\mathrm{CO}_{2}$ storage projects in saline formations, abandoned natural gas reservoirs, or basaltic and ultramafic rocks (U.S. Geological Survey Geologic Carbon Dioxide Storage Resources Assessment Team, 2013a, b, c; Blondes and others, 2019). The $\mathrm{CO}_{2}$ storage associated with $\mathrm{CO}_{2}$-EOR in residual oil zones or unconventional shale reservoirs may also be important future geologic storage options.

5. The National Petroleum Council (2019) report, "Meeting the Dual Challenge - A Roadmap to At-Scale Deployment of Carbon Capture, Use, and Storage," provided a 25-year road map for the United States to achieve "at scale" deployment of carbon capture, use, and storage (CCUS) technologies. These "at scale" technologies could be used to store in geologic reservoirs approximately $500 \mathrm{Mt}$ of anthropogenic $\mathrm{CO}_{2}$ annually, or about 20 percent of the emissions from stationary sources. The results of the USGS $2020 \mathrm{CO}_{2}$-EOR assessment indicate that if $\mathrm{CO}_{2}$ were to be stored only in oil reservoirs undergoing $\mathrm{CO}_{2}$-EOR operations, it would take between 14.8 to 19 years (based on the $\mathrm{P}_{5}$ and $\mathrm{P}_{95} \mathrm{CO}_{2}$ retention values reported in table 4) to utilize the national $\mathrm{CO}_{2}$-EOR reservoir storage capacity. Once again, the results of the USGS $2020 \mathrm{CO}_{2}$-EOR assessment underscore the need to develop injection projects to store anthropogenic $\mathrm{CO}_{2}$ in other underground reservoirs such as saline formations, abandoned natural gas reservoirs, or basaltic or ultramafic rocks to meet the $\mathrm{CO}_{2}$ storage goals set out in the report by the National Petroleum Council (2019).

6. The International Energy Agency (2015) estimated that if anthropogenic $\mathrm{CO}_{2}$ is used in the process, oil produced through conventional $\mathrm{CO}_{2}$-EOR practices, which aim to maximize oil production with a minimal amount of $\mathrm{CO}_{2}$ use, averages about 63 percent less carbon emissions than oil produced through traditional methods (National Petroleum Council, 2019). The results of this USGS assessment are also based on current industry $\mathrm{CO}_{2}$-EOR practices that minimize $\mathrm{CO}_{2}$ use and storage (Warwick and others, 2019) and could be comparable to the conventional $\mathrm{CO}_{2}$-EOR classification in the study by the International Energy Agency (2015). However, if $\mathrm{CO}_{2}$-EOR methods to produce "net carbon negative oil" are applied, as described by Nuñez-López and others (2019), the $\mathrm{CO}_{2}$-EOR process has the potential to further offset the carbon emissions of the produced oil and reduce $\mathrm{CO}_{2}$ emissions to the atmosphere. 


\section{A. Oil that could be produced with $\mathrm{CO}_{2}-\mathrm{EOR}$}

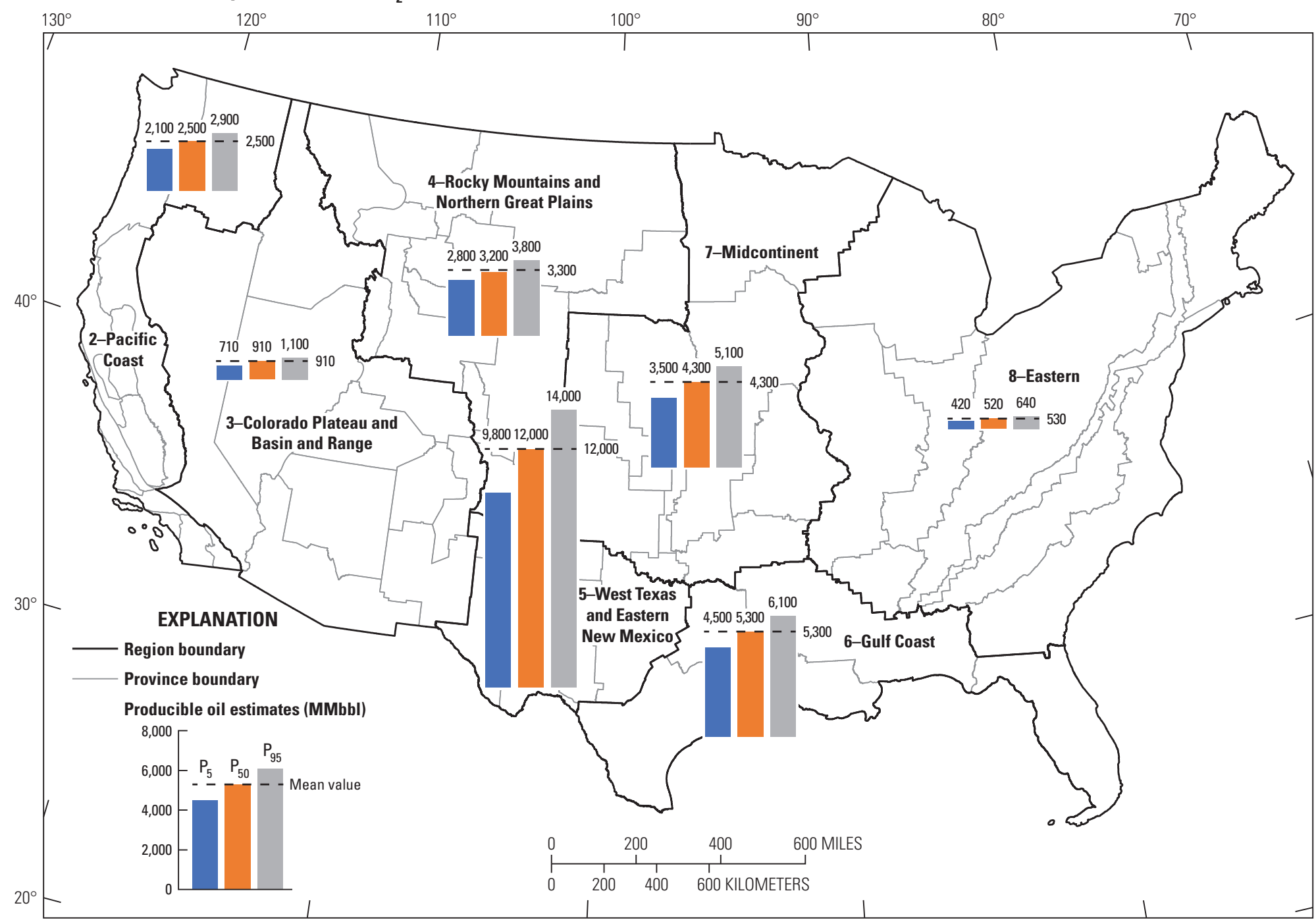

Figure 3. Maps of the conterminous United States and bar graphs showing regional estimates by the U.S. Geological Survey in 2020 of $(A)$ technically recoverable volumes of oil, in millions of petroleum barrels ( $\mathrm{MMbbl}$ ), that could be produced with the application of the carbon dioxide enhanced oil recovery $\left(\mathrm{CO}_{2}\right.$-EOR) process and $(\mathrm{B})$ masses of associated subsurface carbon dioxide $\left(\mathrm{CO}_{2}\right)$, in millions of metric tons (Mt), that could be stored (retained) with the application of the $\mathrm{CO}_{2}$-EOR process in existing miscible oil reservoirs underlying onshore and State waters areas of the conterminous United States. The bar graphs show mean estimates and the $P_{5^{\prime}}, P_{50}$ and $P_{95}$ probability percentiles, which represent the 5-, 50-, and 95-percent probabilities, respectively, that the true resource is less than or equal to the value shown. Regional results are also illustrated by pie charts in figure 2 and cumulative probability graphs in figure 4 and are listed in table 5 . Values are reported to only two significant figures. Resources in Alaska (Region 1), Hawaii, and federally owned offshore areas were not assessed. Petroleum region and province boundaries are from the U.S. Geological Survey's 1995 National Oil and Gas Assessment (NOGA) (Beeman and others, 1996). 
B. $\mathrm{CO}_{2}$ that could be retained with $\mathrm{CO}_{2}-\mathrm{EOR}$



Figure 3. Continued 
A.

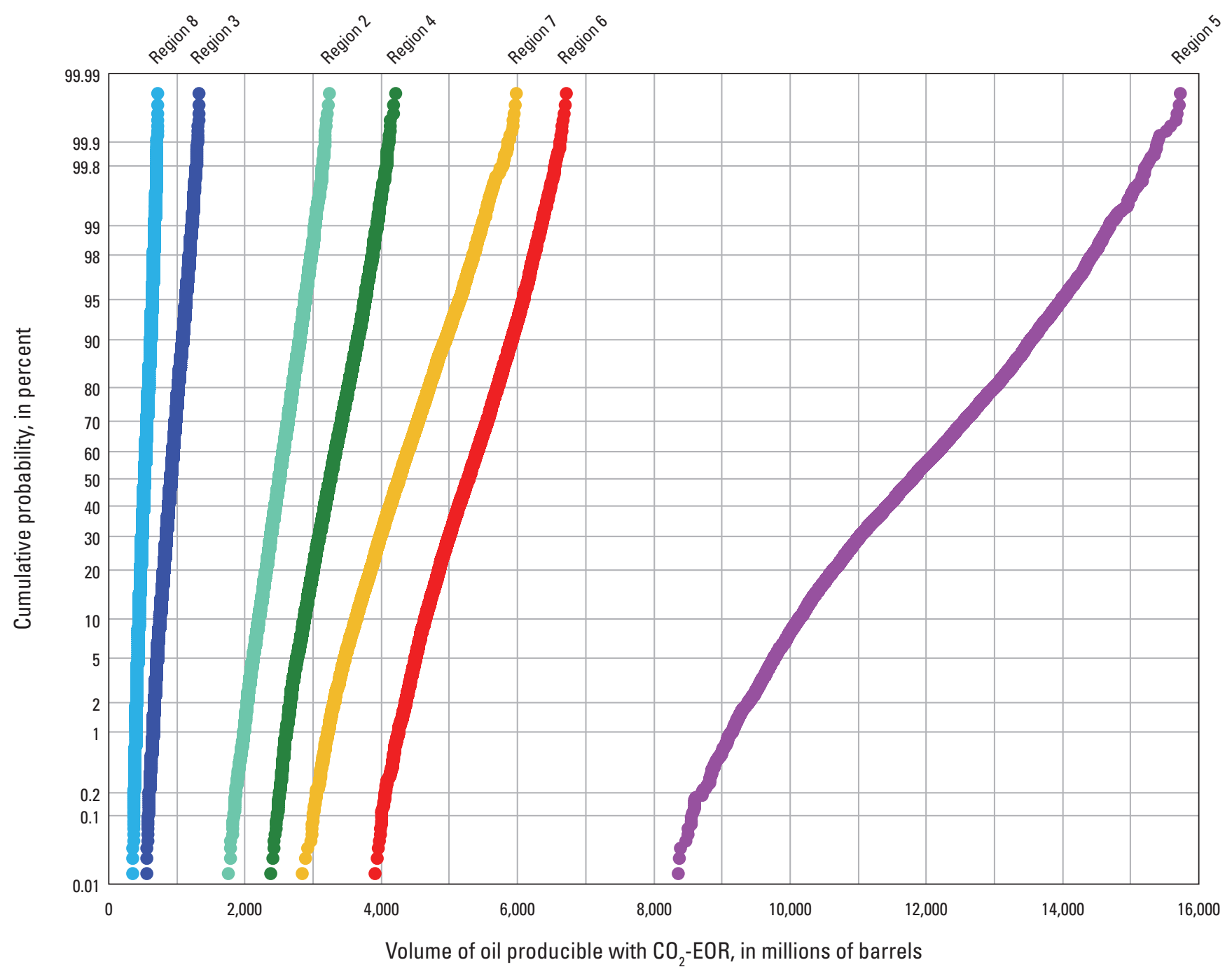

Figure 4. Cumulative probability graphs showing the regional results of a probabilistic assessment by the U.S. Geological Survey in 2020 of $(A)$ technically recoverable volumes of oil, in millions of petroleum barrels (MMbbl), that could be produced with the application of the carbon dioxide enhanced oil recovery $\left(\mathrm{CO}_{2}\right.$-EOR) process and $(B)$ masses of associated subsurface carbon dioxide $\left(\mathrm{CO}_{2}\right)$, in millions of metric tons $(\mathrm{Mt})$, that could be stored (retained) with the application of the $\mathrm{CO}_{2}$-EOR process in existing reservoirs underlying onshore and State waters areas of the conterminous United States. Region numbers by the graph lines refer to the following regions, which are shown in figure 3: Region 2-Pacific Coast, Region 3-Colorado Plateau and Basin and Range, Region 4-Rocky Mountains and Northern Great Plains, Region 5-West Texas and Eastern New Mexico, Region 6-Gulf Coast, Region 7-Midcontinent, and Region 8-Eastern. 


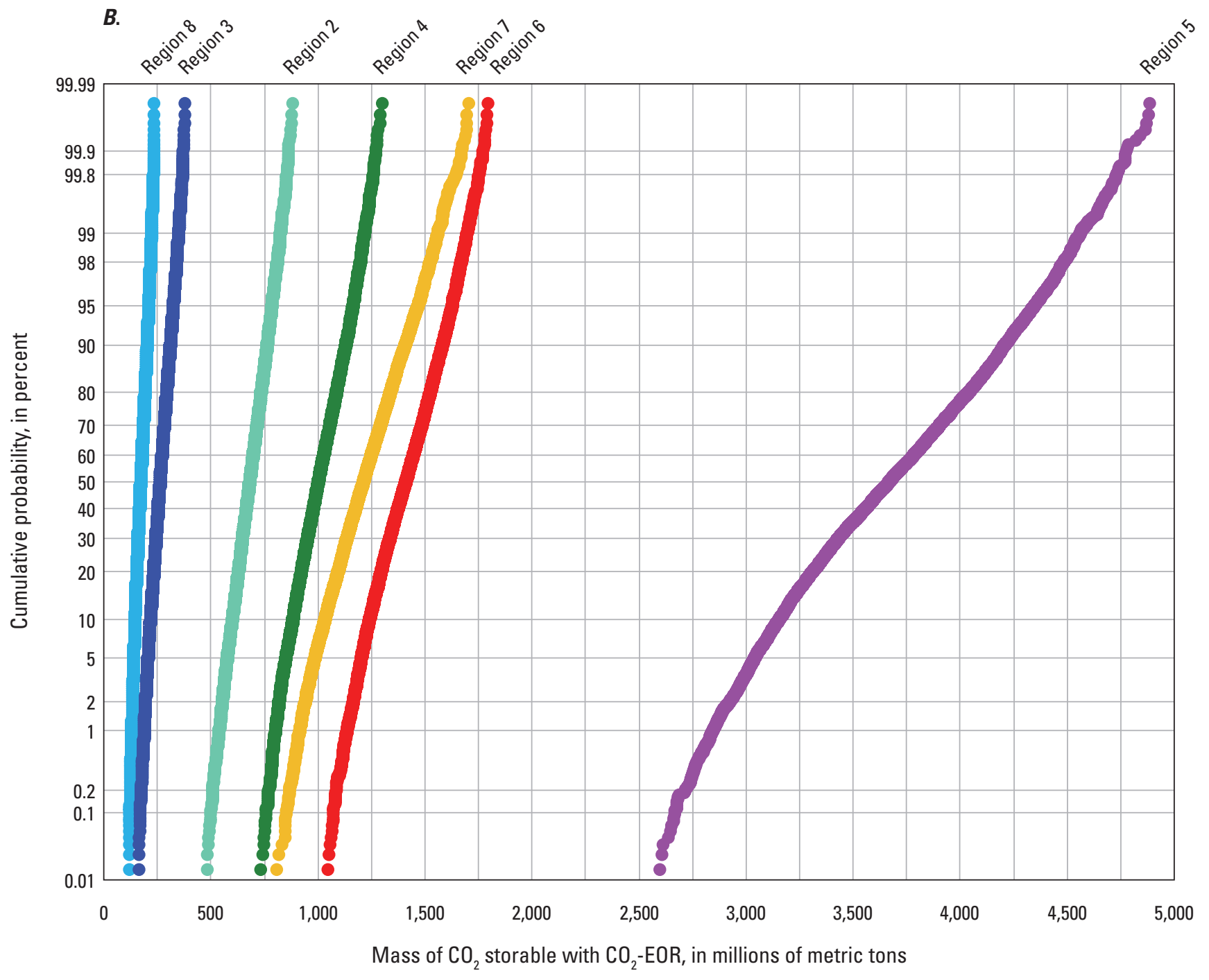

Figure 4. Continued 




Figure 5. Maps of the conterminous United States showing 33 petroleum provinces (shaded and labeled) that were assessed by the U.S. Geological Survey in 2020 for $(A)$ mean technically recoverable volumes of oil, in millions of petroleum barrels (MMbbl), that could be produced with the application of the carbon dioxide enhanced oil recovery (CO ${ }_{2}$-EOR) process and (B) mean masses of associated subsurface carbon dioxide $\left(\mathrm{CO}_{2}\right)$, in millions of metric tons ( $\mathrm{Mt}$ ), that could be stored (retained) with the application of the $\mathrm{CO}_{2}$-EOR process in existing reservoirs underlying onshore and State waters areas of the conterminous United States. Province results are also illustrated in figure 6 and are listed in table 6. Resources in unshaded provinces and in Alaska, Hawaii, and federally owned offshore areas were not assessed. Petroleum province boundaries are from the U.S. Geological Survey's 1995 National Oil and Gas Assessment (NOGA) (Beeman and others, 1996). 


\section{B. $\mathrm{CO}_{2}$ that could be retained with $\mathrm{CO}_{2}-\mathrm{EOR}$}

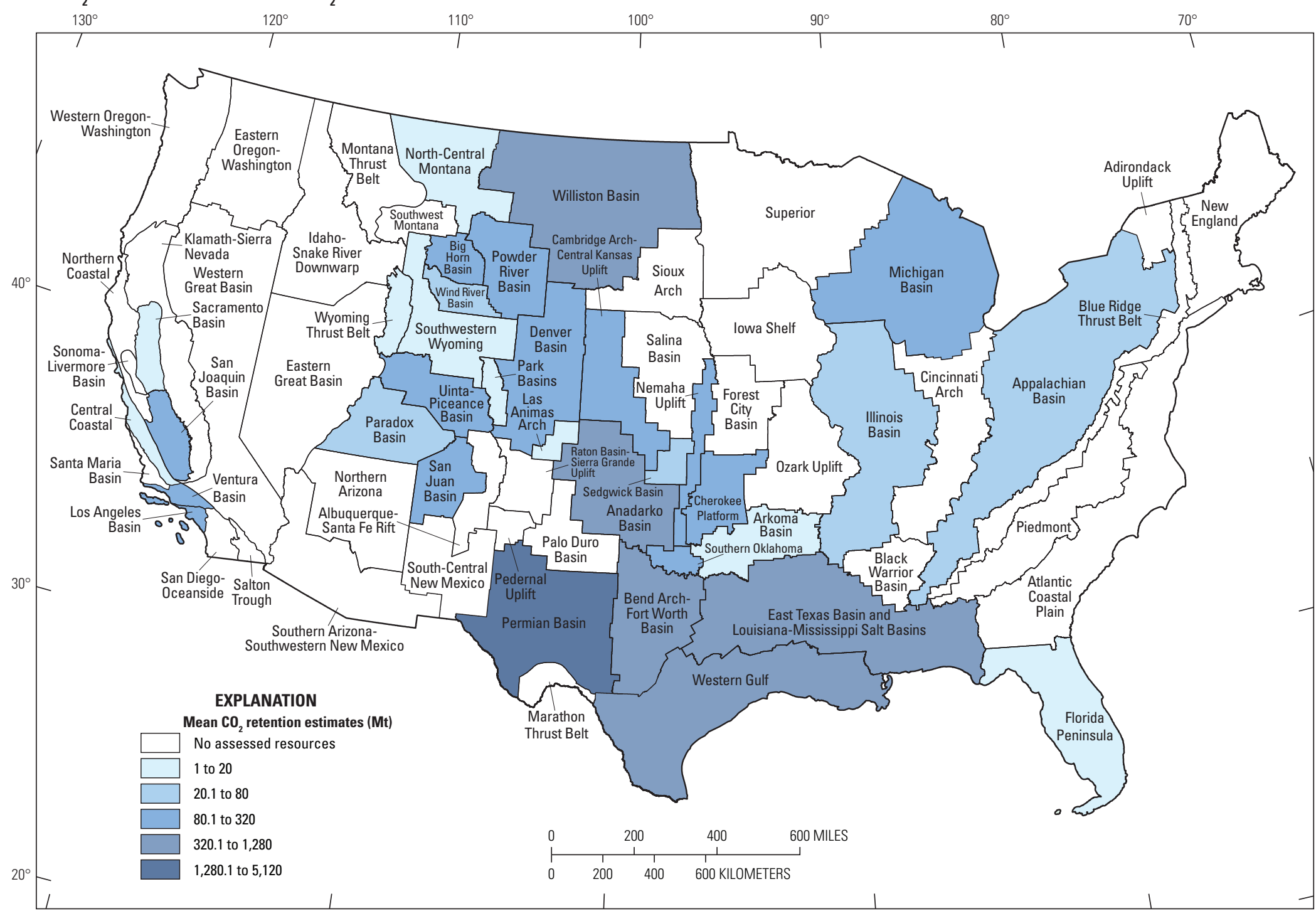

Figure 5. Continued 


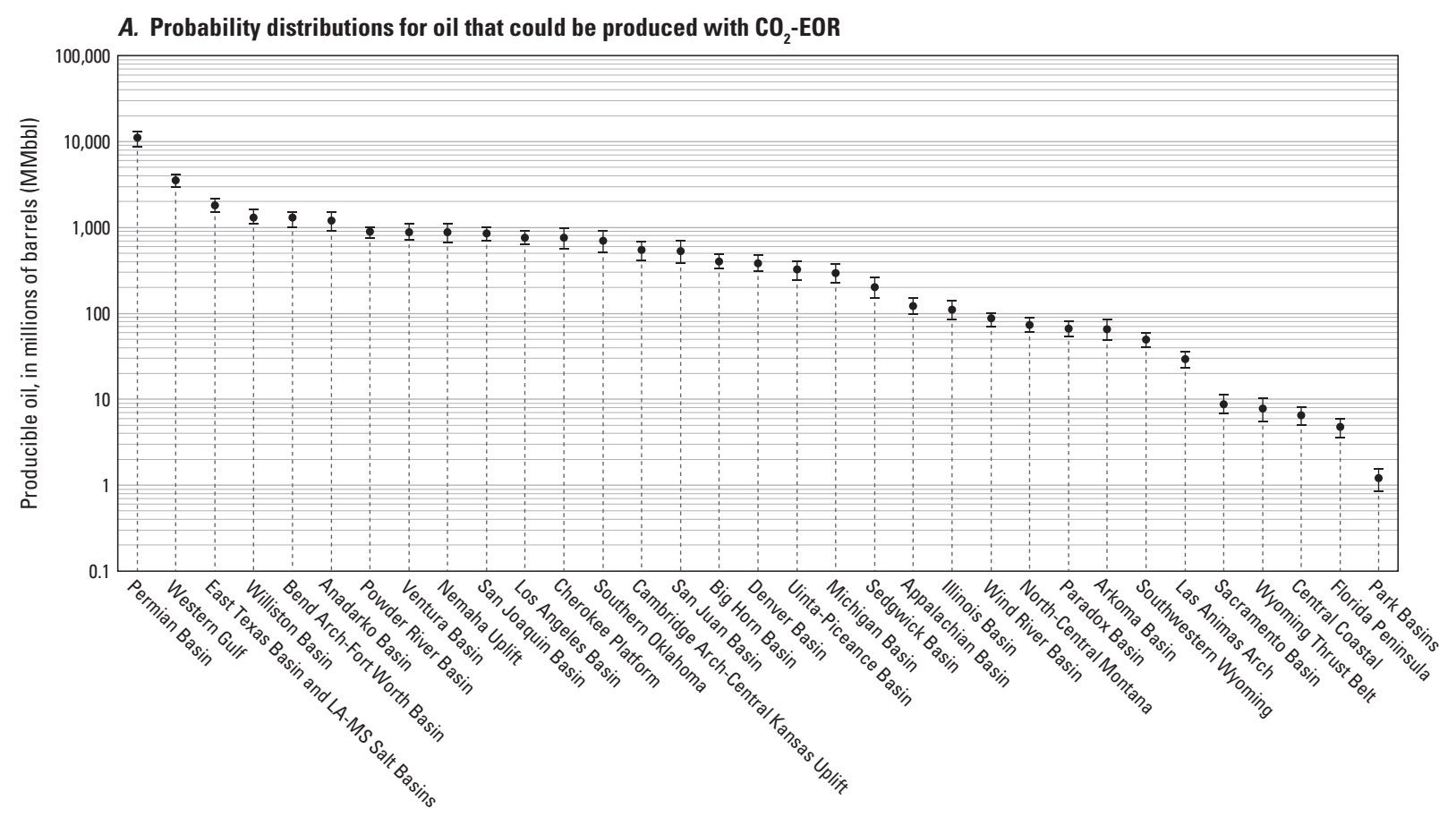

Petroleum province

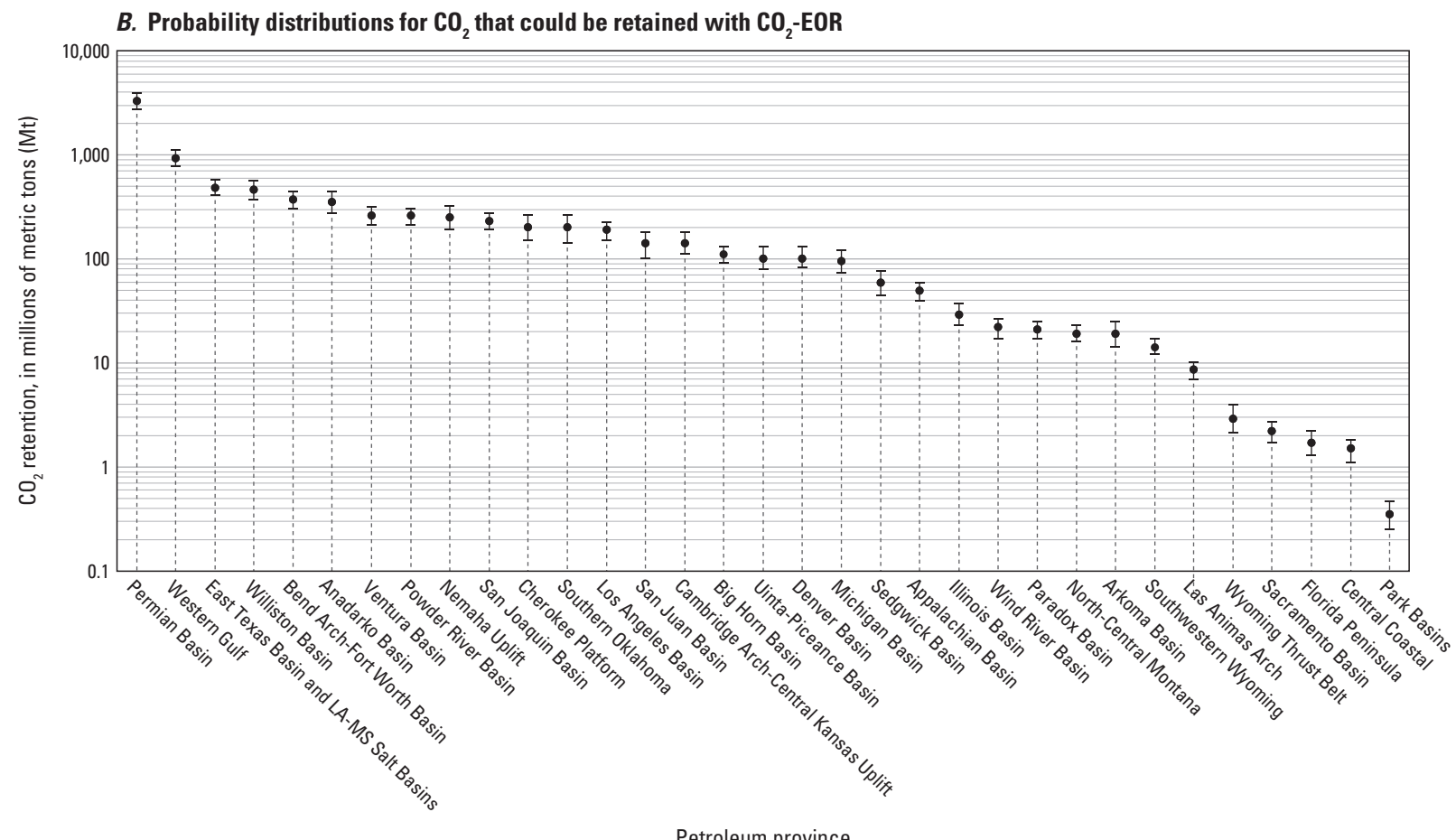

Figure 6. Graphs showing the probability distributions for the provinces estimated by the U.S. Geological Survey in 2020 for $(A)$ technically recoverable volumes of oil, in millions of petroleum barrels (MMbbl), that could be produced with the application of the carbon dioxide enhanced oil recovery $\left(\mathrm{CO}_{2}\right.$-EOR) process and $(B)$ masses of associated carbon dioxide $\left(\mathrm{CO}_{2}\right)$, in millions of metric tons $(\mathrm{Mt})$, that could be stored (retained) with the application of $\mathrm{CO}_{2}$-EOR for each assessed province in the conterminous United States. Each center dot represents the mean assessed resource. The lower bound is the $P_{5}$ percentile, representing a 5 -percent probability that the true resource is less than the value shown. The upper bound is the $P_{95}$ percentile, representing a 95-percent probability that the true resource is less than the value shown. Values are presented on a logarithmic scale. Province outlines are shown in figure 5, and resource estimates are summarized in table 5. LA-MS, Louisiana-Mississippi. 


\section{Comparison of Results With Findings From Previous Assessments}

Previous assessments of recoverable oil resources resulting from applying the $\mathrm{CO}_{2}$-EOR process in the United States have included various assessment methods and economic constraints and have resulted in a wide range of estimates. An initial study by the National Petroleum Council (1976) evaluated three EOR methods: chemical flooding, miscible flooding, and thermal recovery. The study was based on data from 245 reservoirs in California, Texas, and Louisiana. The recovery results obtained from these reservoirs were extrapolated to all reservoirs in the three States and to the United States as a whole. For miscible $\mathrm{CO}_{2}$-EOR, national estimates of ultimate oil recoveries were based on a range of oil prices and resulted in 3 billion barrels (Bbbl) of oil at 10 U.S. dollars per barrel sales price, and 4.4 to $10 \mathrm{Bbbl}$ of oil recovery at $25 \mathrm{U}$.S. dollars per barrel. The National Petroleum Council (1976, table 45) also presented a summary of previous estimates of EOR potential using various EOR methods (chemical, miscible, and thermal). The results range from $2.2 \mathrm{Bbbl}$ of oil at 5 U.S. dollars per barrel (National Petroleum Council, 1976) to as high as 51 to $76 \mathrm{Bbbl}$ of oil at 15 U.S. dollars per barrel (Gulf Universities Research Consortium, 1976).

A second study by the National Petroleum Council (1984a) also evaluated various EOR methods (chemical, miscible, and thermal). That study identified 436 candidate reservoirs nationwide that are suitable for miscible flooding with $\mathrm{CO}_{2}$ or other gases. An economic analysis that included drilling and completion costs and a base economic case using a sales price of 30 U.S. dollars per barrel of oil and a 10-percent minimum discounted cash flow rate of return resulted in an estimated $5.5 \mathrm{Bbbl}$ of oil recovery.

More recent studies also have reported various results. Mohan and others (2008) identified 1,673 potential candidate reservoirs that were miscible to $\mathrm{CO}_{2}$-EOR flooding in the onshore conterminous United States and estimated technically recoverable oil to be about 20 Bbbl. In 2009, a report by Advanced Resources International and Melzer Consulting (International Energy Agency Greenhouse Gas Research and Development Programme, 2009) estimated original oil in place for 54 petroleum-bearing basins worldwide and suggested, on the basis of data about oil properties and production history, that applying $\mathrm{CO}_{2}$-EOR techniques to known world oil reservoirs that are miscible to $\mathrm{CO}_{2}$-EOR flooding would result in $468.5 \mathrm{Bbbl}$ of oil that are technically recoverable and 139 gigatons $(\mathrm{Gt})$ of $\mathrm{CO}_{2}$ retention in amenable reservoirs. If undiscovered oil resources were added, the world totals would be more than 1 trillion barrels of oil that are technically recoverable and about $400 \mathrm{Gt}$ of $\mathrm{CO}_{2}$ retention in $\mathrm{CO}_{2}$-EOR amenable reservoirs. They also estimated that known reservoirs in 14 basins in the United States would yield $60 \mathrm{Bbbl}$ of recoverable oil and $17 \mathrm{Gt}$ of $\mathrm{CO}_{2}$ retention
(International Energy Agency Greenhouse Gas Research and Development Programme, 2009).

A study sponsored by the U.S. Department of Energy National Energy Technology Laboratory (Kuuskraa and others, 2011) found that between 67 and $119 \mathrm{Bbbl}$ of oil would be technically recoverable with between 19.8 and $38 \mathrm{Gt}$ of $\mathrm{CO}_{2}$ retained by applying various "next generation" $\mathrm{CO}_{2}$-EOR processes to $\mathrm{CO}_{2}$-miscible conventional reservoirs in the United States (including Alaska and the Federal offshore areas). Kuuskraa and others (2011) also estimated that if residual oil zones and near-miscible $\mathrm{CO}_{2}$-EOR reservoirs were included, an additional 0.2 to $17.5 \mathrm{Bbbl}$ of oil would be technically recoverable and between 0.1 and $7.3 \mathrm{Gt}$ of $\mathrm{CO}_{2}$ could be stored. The U.S. Department of Energy, National Energy Technology Laboratory (2015) suggested that if current technology were considered, then the total assessment results reported by Kuuskraa and others (2011) might be modified to indicate that the onshore areas of the conterminous United States hold an estimated resource of economically recoverable oil of $24 \mathrm{Bbbl}$ and associated $\mathrm{CO}_{2}$ storage of approximately $9 \mathrm{Gt}$.

The International Energy Agency (2015) suggested that globally over the next 50 years, as much as $375 \mathrm{Bbbl}$ may be technically recovered through miscible $\mathrm{CO}_{2}$-EOR using "Maximum Storage EOR+" activities aimed to maximize $\mathrm{CO}_{2}$ storage and oil production. The associated global $\mathrm{CO}_{2}$ storage potential of "Maximum Storage EOR+" activities ranges from 60 to $360 \mathrm{Gt}$ of $\mathrm{CO}_{2}$. The International Energy Agency (2015) estimated that approximately 10 percent of those resources, or $37.5 \mathrm{Bbbl}$ of technically recoverable oil and $36 \mathrm{Gt}$ of $\mathrm{CO}_{2}$ storage, are located in the United States.

Finally, the National Petroleum Council (2019, table 8-1) reported that the $\mathrm{CO}_{2}$ storage capacity for the conventional oil reservoirs in the United States associated with $\mathrm{CO}_{2}$-EOR ranges from 30 to $45 \mathrm{Gt}$, whereas the national storage capacity could be as great as 55 to $119 \mathrm{Gt}$ if the $\mathrm{CO}_{2}$-EOR storage potential in ROZs and offshore conventional reservoirs were included in the estimate. The National Petroleum Council (2019) suggested that development of new technologies and economic incentives such as tax breaks for $\mathrm{CO}_{2}$ storage or carbon taxes or fines for $\mathrm{CO}_{2}$ emissions could add significant $\mathrm{CO}_{2}$ demand and associated storage capacity, potentially enabling the total $\mathrm{CO}_{2}$ storage associated with $\mathrm{CO}_{2}$-EOR to range between 274 and 479 Gt. No assessment considerations or methods were presented in the National Petroleum Council (2019) report.

As is apparent from this summary, previous estimates for technically recoverable oil from $\mathrm{CO}_{2}$-EOR with associated $\mathrm{CO}_{2}$ retention using current techniques in the United States range from 2.2 to $119 \mathrm{Bbbl}$ of oil (National Petroleum Council, 1976; Kuuskraa and others, 2011) and from 17 to $38 \mathrm{Gt}$ of $\mathrm{CO}_{2}$ retained in the reservoir (International Energy Agency Greenhouse Gas Research and Development Programme, 2009). The results of the 2020 U.S. Geological Survey assessment provided in this circular, with a mean of $29 \mathrm{Bbbl}$ of technically recoverable oil and $8.4 \mathrm{Gt}$ of $\mathrm{CO}_{2}$ stored, are comparable to the results of previous assessments summarized above. 


\section{Conclusions}

The U.S. Geological Survey (USGS) recently completed an evaluation of the technically recoverable oil resources that may be produced by using current carbon dioxide enhanced oil recovery $\left(\mathrm{CO}_{2}\right.$-EOR) technologies in amenable oil reservoirs underlying the onshore and State waters areas of the conterminous United States. The assessment also includes estimates of the masses of $\mathrm{CO}_{2}$ that could be retained in the assessed oil reservoirs following the application of $\mathrm{CO}_{2}$-EOR. By using the assessment methodology of Warwick and others (2019), the assessment team members obtained mean estimates of approximately 29,000 million barrels (MMbbl) of technically recoverable oil and 8,400 million metric tons (Mt) of $\mathrm{CO}_{2}$ retention.

The USGS assessment team evaluated more than 3,500 oil reservoirs that were determined to be miscible to injected $\mathrm{CO}_{2}$. The assessed reservoirs are located in 185 previously defined USGS plays in 33 petroleum provinces of 7 national regions; all assessed petroleum provinces were sedimentary basins. The West Texas and Eastern New Mexico region and the Gulf Coast region contain 60 percent of the mean assessed $\mathrm{CO}_{2}$-EOR recoverable oil potential and 61 percent of the mean assessed $\mathrm{CO}_{2}$ retention. Other regions with significant $\mathrm{CO}_{2}$-EOR resource potential include the Midcontinent region and the Rocky Mountains and Northern Great Plains region.

The National Petroleum Council (2019) proposed a roadmap for the development of "at scale" carbon capture, use, and storage (CCUS) technologies such as $\mathrm{CO}_{2}$-EOR, to help reduce national $\mathrm{CO}_{2}$ emissions. The roadmap proposes that the United States store approximately $500 \mathrm{Mt}$ of anthropogenic $\mathrm{CO}_{2}$ annually in geologic reservoirs, or about 20 percent of the emissions from stationary sources in the United States. The results of the USGS $2020 \mathrm{CO}_{2}$-EOR assessment indicate that the $\mathrm{CO}_{2}$-EOR process can help to meet only part of the goal set forth by the National Petroleum Council (2019). Therefore, to meet the goal of storing $500 \mathrm{Mt}$ of $\mathrm{CO}_{2}$ annually, there is a need to use several approaches simultaneously: (1) couple standard $\mathrm{CO}_{2}$-EOR practices with strategies to enhance storage of $\mathrm{CO}_{2}$ in oil reservoirs and (2) develop injection projects to store anthropogenic $\mathrm{CO}_{2}$ in other underground reservoirs such as saline formations, abandoned natural gas reservoirs, or basaltic or ultramafic rocks. This assessment fulfills the requirements of the Energy Independence and Security Act of 2007 (U.S. Congress, 2007) that requested the USGS to estimate the "potential volumes of oil and gas recoverable by injection and sequestration of industrial carbon dioxide in potential sequestration formations" (42 U.S.C. 17271(b)(4)).

\section{References Cited}

Advanced Resources International, 2021, A survey of U.S. $\mathrm{CO}_{2}$ enhanced oil recovery projects: Advanced Resources International online report, 4 p., accessed July 26, 2021, at https://www.adv-res.com/pdf/2019-US-CO2-EOR-SurveyARI-4272021.pdf.

Appalachian Oil and Natural Gas Research Consortium, 1996, Enhancement of the TORIS [Tertiary Oil Recovery Information System] data base of Appalachian basin oil fields-Final report: U.S. Department of Energy [technical report] DOE/MC/28176-1, prepared by Appalachian Oil and Natural Gas Research Consortium, 21 p., accessed February 9, 2018, at https://dx.doi.org/10.2172/251348.

Attanasi, E.D., 2017, Using $\mathrm{CO}_{2}$ Prophet to estimate recovery factors for carbon dioxide enhanced oil recovery, chap. B of Verma, M.K., ed., Three approaches for estimating recovery factors in carbon dioxide enhanced oil recovery: U.S. Geological Survey Scientific Investigations Report 2017-5062, p. B1-B10, accessed May 4, 2020, at https://doi.org/10.3133/sir20175062B.

Azzolina, N.A., Nakles, D.V., Gorecki, C.D., Peck, W.D., Ayash, S.C., Melzer, L.S., and Chatterjee, S., 2015, $\mathrm{CO}_{2}$ storage associated with $\mathrm{CO}_{2}$ enhanced oil recovery- $\mathrm{A}$ statistical analysis of historical operations: International Journal of Greenhouse Gas Control, v. 37, p. 384-397, accessed April 30, 2016, at https://doi.org/10.1016/j. ijggc.2015.03.037.

Beeman, W.R., Obuch, R.C., and Brewton, J.D., comps., 1996, Digital map data, text, and graphical images in support of the 1995 national assessment of United States oil and gas resources: U.S. Geological Survey Digital Data Series DDS-35, 1 CD-ROM.

Blondes, M.S., Brennan, S.T., Merrill, M.D., Buursink, M.L., Warwick, P.D., Cahan, S.M., Cook, T.A., Corum, M.D., Craddock, W.H., DeVera, C.A., Drake, R.M., II, Drew, L.J., Freeman, P.A., Lohr, C.D., Olea, R.A., Roberts-Ashby, T.L., Slucher, E.R., and Varela, B.A., 2013, National assessment of geologic carbon dioxide storage resourcesMethodology implementation: U.S. Geological Survey Open-File Report 2013-1055, 26 p., accessed March 26, 2020, at https://pubs.usgs.gov/of/2013/1055/.

Blondes, M.S., Merrill, M.D., Anderson, S.T., and DeVera, C.A., 2019, Carbon dioxide mineralization feasibility in the United States: U.S. Geological Survey Scientific Investigations Report 2018-5079, 29 p., accessed March 26, 2020, at https://doi.org/10.3133/sir20185079. 
Blondes, M.S., Schuenemeyer, J.H., Olea, R.A., and Drew, L.J., 2013, Aggregation of carbon dioxide sequestration storage assessment units: Stochastic Environmental Research and Risk Assessment, v. 27, no. 8, p. 1839-1859.

Brennan, S.T., Burruss, R.C., Merrill, M.D., Freeman, P.A., and Ruppert, L.F., 2010, A probabilistic assessment methodology for the evaluation of geologic carbon dioxide storage: U.S. Geological Survey Open-File Report 2010-1127, 31 p., accessed March 26, 2020, at https://pubs.usgs.gov/ of/2010/1127.

British Columbia Oil and Gas Commission, 2014, Policy for determining primary product of oil or gas (update of August 6, 2014): British Columbia Oil and Gas Commission Reservoir Engineering Department website, 1 p., accessed August 11, 2021, at https:/www.bcogc.ca/files/operationsdocumentation/Reservoir-Management/ProductionAllowables/policy-determination-primary-product-gas-or-oilaugust-release-2014.pdf.

Carolus, M., Biglarbigi, K., Warwick, P.D., Attanasi, E.D., Freeman, P.A., and Lohr, C.D., 2017, Overview of a comprehensive resource database for the assessment of recoverable hydrocarbons produced by carbon dioxide enhanced oil recovery (ver. 1.1, June 2018): U.S. Geological Survey Techniques and Methods, book 7, chap. C16, 31 p., accessed June 12, 2018, at https://doi.org/10.3133/tm7C16.

Dobitz, J.K., and Prieditis, J., 1994, A steam tube model for the PC: SPE/DOE Ninth Symposium on Improved Oil Recovery, Tulsa, Okla., April 17-20, 1994, paper SPE-27750-MS, 8 p.

Dykstra, H., and Parsons, R.L., 1950, The prediction of oil recovery by waterflooding, in Secondary recovery of oil in the United States ( $2 \mathrm{~d}$ ed.): New York, American Petroleum Institute, p. 160-174.

Everitt, B.S., and Skrondal, A., 2010, The Cambridge dictionary of statistics (4th ed.): Cambridge, England, Cambridge University Press, 478 p.

Freeman, P.A., and Attanasi, E.D., 2015, Profiles of reservoir properties of oil-bearing plays for selected petroleum provinces in the United States (ver. 1.1, February 2016): U.S. Geological Survey Open-File Report 2015-1195, 68 p., accessed October 28, 2020, at https://dx.doi.org/10.3133/ ofr20151195.

Gulf Universities Research Consortium, 1976, Preliminary field test recommendations and prospective crude oil fields of reservoirs for high priority field testing: Oak Ridge, Tenn., U.S. Energy Research and Development Administration, Technical Information Center, prepared by Gulf Universities Research Consortium [report 148], 270 p.
Hill, B., Hovorka, S., and Melzer, S., 2013, Geologic carbon storage through enhanced oil recovery: Energy Procedia, v. 37, p. 6808-6830, accessed June 29, 2020, at https://doi.org/10.1016/j.egypro.2013.06.614.

Houseknecht, D.W., Whidden, K.J., Connors, C.D., Lease, R.O., Schenk, C.J., Mercier, T.J., Rouse, W.A., Botterell, P.J., Smith, R.A., Sanders, M.M., Craddock, W.H., DeVera, C.A., Garrity, C.P., Buursink, M.L., Karacan, C.O., Heller, S.J., Moore, T.E., Dumoulin, J.A., Tennyson, M.E., French, K.L., Woodall, C.A., Drake, R.M., II, Marra, K.R., Finn, T.M., Kinney, S.A., and Shorten, C.M., 2020, Assessment of undiscovered oil and gas resources in the central North Slope of Alaska, 2020: U.S. Geological Survey Fact Sheet 2020-3001, 4 p., accessed October 29, 2020, at https://doi.org/10.3133/fs20203001.

International Energy Agency, 2015, Storing $\mathrm{CO}_{2}$ through enhanced oil recovery: International Energy Agency Insights Series 2015, 46 p., accessed August 11, 2021, at https://nachhaltigwirtschaften.at/resources/iea_pdf/reports/ iea_ghg_storing_co2_trough_enhanced_oil_recovery.pdf.

International Energy Agency, 2019, World energy outlook 2019: International Energy Agency, report, 807 p., accessed March 27, 2020, at https://www.iea.org/reports/worldenergy-outlook-2019.

International Energy Agency Greenhouse Gas Research and Development Programme, 2009, $\mathrm{CO}_{2}$ storage in depleted oilfields - Global application criteria for carbon dioxide enhanced oil recovery: International Energy Agency Greenhouse Gas Research and Development Programme Technical Report 2009-12, prepared by Advanced Resources International and Melzer Consulting, 154 p., accessed March 26, 2020, at https://www.ieaghg.org/docs/ General_Docs/Reports/2009-12.pdf.

IHS Inc., 2011, ENERDEQ U.S. well data: IHS Inc., database, accessed January 20, 2011, at http://energy.ihs.com/.

IHS Inc., 2012, PIDM [Petroleum Information Data Model] relational U.S. well data [data current as of December 23, 2011]: Englewood, Colo., IHS Inc. database.

Jahangiri, H.R., and Zhang, D., 2010, Optimization of carbon dioxide sequestration and enhanced oil recovery in oil reservoir: Society of Petroleum Engineers, Western North America Regional Meeting, Anaheim, Calif., May 27-29, 2010, paper SPE-133594-MS, 9 p.

Jensen, J.L., Lake, L.W., Corbett, P.W.M., and Goggin, D.J., 1997, Statistics for petroleum engineers and geoscientists: Upper Saddle River, N.J., Prentice Hall, 390 p. 
Jin, L., Hawthorne, S., Sorensen, J., Pekot, L., Kurz, B., Smith, S., Heebink, L., Herdegen, V., Bosshart, N., Torres, J., Dalkhaa, C., Peterson, K., Gorecki, C., Steadman, E., and Harju, J., 2017, Advancing $\mathrm{CO}_{2}$ enhanced oil recovery and storage in unconventional oil play-Experimental studies on Bakken shales: Applied Energy, v. 208, p. 171-183, accessed June 29, 2020, at https://doi.org/10.1016/j. apenergy.2017.10.054.

Kaufman, G.M., Olea, R.A., Faith, R., and Blondes, M.S., 2018, Probabilistic aggregation of uncertain geological resources: Mathematical Geosciences, v. 50, no. 7, p. 729-752, accessed May 5, 2020, at https://doi.org/10.1007/s11004-018-9747-9.

Klett, T.R., Schmoker, J.W., Charpentier, R.R., Ahlbrandt, T.S., and Ulmishek, G.F., 2005, Glossary, chap. 25 of U.S. Geological Survey Southwestern Wyoming Province Assessment Team, Petroleum systems and geologic assessment of oil and gas in the Southwestern Wyoming Province, Wyoming, Colorado, and Utah: U.S. Geological Survey Digital Data Series DDS-69-D, 3 p., on CD-ROM. [Also available at https://pubs.usgs.gov/dds/dds-069/ dds-069-d/.]

Koottungal, L., 2012, 2012 worldwide EOR survey: Oil \& Gas Journal, v. 110, no. 4 (April 2, 2012), p. 57-69, accessed April 30, 2020, at https://www.ogj.com/articles/print/ vol-110/issue-4/general-interest/special-report-eor-heavyoil-survey/2012-worldwide-eor-survey.html.

Koottungal, L., 2014, 2014 worldwide EOR survey: Oil \& Gas Journal, v. 112, no. 4 (April 7, 2014), p. 79-91, accessed April 30, 2020, at https://www.ogj.com/ogj-surveydownloads/worldwide-eor/document/17299687/2014worldwide-eor-survey.

Kuuskraa, V., Murray, B., and Petrusak, R., 2020, Increasing shale oil recovery and $\mathrm{CO}_{2}$ storage with cyclic $\mathrm{CO}_{2}$ enhanced oil recovery: U.S. Department of Energy, Office of Fossil Energy, and United States Energy Association, [report], prepared by Advanced Resources International under sub-agreement USEA/DOE-002415-20-01, variously paged [189 p.], accessed August 12, 2021, at https://usea.org/sites/ default/files/USEA $\% 20$ ARI $\% 20$ Shale $\% 20$ Recovery $\% 20$ Storage\%20CO2\%20EOR\%20SEP_22_2020\%20 \%28Reduced\%20File\%20Size\%29\%20\%281\%29.pdf.

Kuuskraa, V.A., Van Leeuwen, T., and Wallace, M., 2011, Improving domestic energy security and lowering $\mathrm{CO}_{2}$ emissions with "Next Generation" $\mathrm{CO}_{2}$-enhanced oil recovery $\left(\mathrm{CO}_{2}\right.$-EOR): U.S. Department of Energy, National Energy Technology Laboratory, [report] DOE/NETL-2011/1504, prepared by Advanced Resources International, variously paged, accessed August 12, 2021, at https://www.netl.doe.gov/ sites/default/files/netl-file/NextGen_CO2_EOR_06142011.pdf.

Lake, L.W., 1989, Enhanced oil recovery: Englewood Cliffs, N.J., Prentice Hall, 550 p.
Mamora, D.D., and Seo, J.G., 2002, Enhanced gas recovery by carbon dioxide sequestration in depleted gas reservoirs: Society of Petroleum Engineers, Annual Technical Conference and Exhibition, San Antonio, Tex., September 29-October 2, 2002, paper SPE-77347-MS, 9 p.

McGlade, C., 2019, Can $\mathrm{CO}_{2}$-EOR really provide carbon-negative oil?: International Energy Agency, commentary (April 11, 2019), 4 p., accessed September 24, 2020, at https://www.iea.org/ commentaries/can-co2-eor-really-provide-carbon-negative-oil.

Meyer, M.A., and Booker, J.M., 2001, Eliciting and analyzing expert judgement-A practical guide: Alexandria, Va., ASA-SIAM [American Statistical Association-Society for Industrial and Applied Mathematics], $459 \mathrm{p}$.

Midwest Geological Sequestration Consortium, 2012, Demonstration of $\mathrm{CO}_{2}$-enhanced oil recovery potential in the Illinois Basin-Technical report: Champaign, Ill., Illinois State Geological Survey, Prairie Research Institute, 36 p., accessed August 12, 2021, at https://www.ideals.illinois.edu/bitstream/ handle/2142/102182/MGSC\%20Final\%20Phase $\% 20$ II\%20 Report.pdf? sequence=2\&isAllowed=y. [Prepared under U.S. Department of Energy cooperative agreement DE-FC2605NT42588.]

Mohan, H., Carolus, M.J., and Biglarbigi, K., 2008, The potential for additional carbon dioxide flooding projects in the United States: Society of Petroleum Engineers Improved Oil Recovery Symposium, Tulsa, Oklahoma, U.S.A., April 20-23, 2008, paper SPE-113975-MS, 9 p.

National Petroleum Council, 1976, Enhanced oil recovery-An analysis of the potential for enhanced oil recovery from known fields in the United States-1976 to 2000: [Washington D.C.], National Petroleum Council, 231 p., accessed March 27, 2020, at https://www.npc.org/reports/rby.html.

National Petroleum Council, 1984a, Enhanced oil recovery: Washington, D.C., National Petroleum Council, variously paged [285 p.], accessed August 10, 2015, at https://www.npc.org/reports/rby.html.

National Petroleum Council, 1984b, Tertiary Oil Recovery Information System (TORIS) data base: National Petroleum Council, accessed archived file August 12, 2021, at https://edx.netl.doe.gov/dataset/22b7817c-2360-44098bae-de279e53bfec/resource/77fbc648-b4e0-4723-82452 be $970 \mathrm{dcd} 545$.

National Petroleum Council, 2019, $\mathrm{CO}_{2}$ enhanced oil recovery, chap. 8 of Volume III, Analysis of CCUS technologies, of National Petroleum Council, Meeting the dual challenge- A roadmap to at-scale deployment of carbon capture, use, and storage [CCUS]: National Petroleum Council, 34 p., accessed August 14, 2019, at https://dualchallenge.npc.org/. 
Nehring Associates, 2012, The significant oil and gas fields of the United States database [data current as of December 2012]: Colorado Springs, Colo., Nehring Associates, database.

Nuñez-López, V., and Moskal, E., 2019, Potential of $\mathrm{CO}_{2}$-EOR for near-term decarbonization: Frontiers in Climate, v. 1, article 5, 14 p., accessed May 12, 2020, at https://doi.org/10.3389/fclim.2019.00005.

Nuñez-López, V., Gil-Egui, R., Hosseininoosheri, P., Hovorka, S.D., and Lake, L.W., 2019, Final report-Carbon life cycle analysis of $\mathrm{CO}_{2}$-EOR for net carbon negative oil (NCNO) classification: U.S. Department of Energy, National Energy Technology Laboratory, 108 p., accessed August 13, 2021, at https://www.osti.gov/biblio/1525864 . [Work performed under agreement DE-FE0024433.]

Oldenburg, C.M., and Benson, S.M., 2002, $\mathrm{CO}_{2}$ injection for enhanced gas production and carbon sequestration: Society of Petroleum Engineers International Petroleum Conference and Exhibition in Mexico, Villahermosa, Mexico, February 10-12, 2002, paper SPE-74367-MS, 10 p.

Olea, R.A., 2015, $\mathrm{CO}_{2}$ retention values in enhanced oil recovery: Journal of Petroleum Science and Engineering, v. 129 , p. 23-28.

Prieditis, J., and Brugman, R., 1993, Effects of recent relative permeability data on $\mathrm{CO}_{2}$ flood modeling, in 68th Annual Technical Conference and Exhibition of the Society of Petroleum Engineers, Houston, Texas, October 3-6, 1993, p. 467-481, paper SPE-26650-MS.

Riley, R.A., Harper, J.A., Harrison, W.B., III, Barnes, D.A., Nuttall, B.C., Avary, K.L., Wahr, A.M., Baranoski, M.T., Slater, B.E., Harris, D.C., and Kelley, S.R., 2010, Evaluation of $\mathrm{CO}_{2}$-enhanced oil recovery and sequestration opportunities in oil and gas fields in the MRCSP region-MRCSP Phase II topical report, October 2005-October 2010: Midwest Regional Carbon Sequestration Partnership, 177 p., accessed August 14, 2019, at https://irp-cdn.multiscreensite.com/5b322158/files/ uploaded/topical_3_enhanced_oil_recovery.pdf. [Prepared under U.S. Department of Energy cooperative agreement DE-FC26-05NT42589 and OCDO (Ohio Coal Development Office) grant agreement DC-05-13.]

Schmoker, J.W., and Klett, T.R., 2005, U.S. Geological Survey assessment concepts for conventional petroleum accumulations, chap. 19 of U.S. Geological Survey Southwestern Wyoming Province Assessment Team, Petroleum systems and geologic assessment of oil and gas in the Southwestern Wyoming Province, Wyoming, Colorado, and Utah: U.S. Geological Survey Digital Data Series DDS-69-D, 6 p., accessed April 30, 2020, at https://pubs.usgs.gov/dds/dds-069/dds069-d/REPORTS/69_D_CH_19.pdf.
Stalkup, F.I., Jr., 1983, Miscible displacement: Society of Petroleum Engineers Monograph 8, 204 p.

Thormahlen, L.F., 1999, Boundary development on the Outer Continental Shelf: Minerals Management Service Mapping and Boundary Branch, OCS report MMS 99-0006, [19] p., accessed April 30, 2020, at https://www.boem.gov/BOEMNewsroom/Library/Publications/1999/99-0006-pdf.aspx.

Tzimas, E., Georgakaki, A., Garcia Cortes, C., and Peteves, S.D., 2005, Enhanced oil recovery using carbon dioxide in the European energy system: Petten, The Netherlands, European Commission, Directorate General Joint Research Centre (DG JRC), Institute for Energy, Report EUR 21895 EN, December 2005, 118 p., accessed August 17, 2021, at https://op.europa.eu/en/publication-detail/-/publication/ f74be8a8-5641-41d3-8273-241aaab599ca.

U.S. Congress, 2007, Energy Independence and Security Act of 2007-Public Law 110-140: U.S. Government Printing Office, 311 p., accessed March 26, 2020, at https:/www.govinfo.gov/ content/pkg/PLAW-110publ140/pdf/PLAW-110publ140.pdf.

U.S. Department of Energy, National Energy Technology Laboratory, 2015, Carbon storage atlas (5th ed.; Atlas V): U.S. Department of Energy, National Energy Technology Laboratory Report DOE/NETL-2015/1709, 113 p., accessed April 20, 2020, at http://www.netl.doe.gov/coal/carbonstorage/strategic-program-support/natcarb-atlas.

U.S. Department of Energy, National Energy Technology Laboratory, 2021, Carbon dioxide 101: U.S. Department of Energy, National Energy Technology Laboratory website, accessed August 26, 2021, at https://netl.doe.gov/coal/carbonstorage/faqs/carbon-dioxide-101.

U.S. Energy Information Administration, 2020, Petroleum and other liquids - Crude oil production [for 2014-2019 and revised monthly]: U.S. Energy Information Administration website, accessed June 22, 2020, at https://www.eia.gov/ dnav/pet/pet_crd_crpdn_adc_mbbl_a.htm.

U.S. Environmental Protection Agency, 2018, Overview of greenhouse gases - Carbon dioxide emissions: U.S. Environmental Protection Agency website, accessed April 20, 2020, at https://www.epa.gov/ghgemissions/ overview-greenhouse-gases\#CO2\%20references.

U.S. Environmental Protection Agency, 2020, Inventory of U.S. greenhouse gas emissions and sinks - 1990-2018: U.S. Environmental Protection Agency [Report] EPA 430-R20-002, variously paged, plus additional online data tables, accessed April 29, 2020, at https:/www.epa.gov/ghgemissions/ inventory-us-greenhouse-gas-emissions-and-sinks. 
U.S. Geological Survey Geologic Carbon Dioxide Storage Resources Assessment Team, 2013a, National assessment of geologic carbon dioxide storage resources-Data (ver. 1.1, September 2013): U.S. Geological Survey Data Series 774, 13 p., plus 2 appendixes and 2 large tables in separate files, accessed March 26, 2020, at https://pubs.usgs.gov/ds/774/. [Supersedes ver. 1.0, released in June 2013.]

U.S. Geological Survey Geologic Carbon Dioxide Storage Resources Assessment Team, 2013b, National assessment of geologic carbon dioxide storage resources-Results (ver. 1.1, September 2013): U.S. Geological Survey Circular 1386, 41 p., accessed March 26, 2020, at https://pubs.usgs.gov/circ/1386/. [Supersedes ver. 1.0, released in June 2013.]

U.S. Geological Survey Geologic Carbon Dioxide Storage Resources Assessment Team, 2013c, National assessment of geologic carbon dioxide storage resources-Summary (ver. 1.1, September 2013): U.S. Geological Survey Fact Sheet 2013-3020, 6 p., accessed March 26, 2020, at https://pubs.usgs.gov/fs/2013/3020/. [Supersedes ver. 1.0, released in June 2013.]

U.S. Geological Survey National Oil and Gas Resource Assessment Team, 1995, 1995 national assessment of United States oil and gas resources: U.S. Geological Survey Circular 1118, 20 p., accessed March 26, 2020, at https://pubs.usgs.gov/circ/1995/circ1118/execsum.html.

van der Meer, L., Kreft, E., Geel, C., and Hartman, J.J., 2005, $\mathrm{K} 12-\mathrm{B}-\mathrm{A}$ test site for $\mathrm{CO}_{2}$ storage and enhanced gas recovery: Society of Petroleum Engineers, Europec/EAGE Annual Conference, Madrid, Spain, June 13-16, 2005, paper SPE-94128-MS, 9 p.

Verma, M.K., 2015, Fundamentals of carbon dioxide-enhanced oil recovery $\left(\mathrm{CO}_{2}\right.$-EOR) - A supporting document of the assessment methodology for hydrocarbon recovery using $\mathrm{CO}_{2}-$ EOR associated with carbon sequestration: U.S. Geological Survey Open-File Report 2015-1071, 19 p., accessed May 4, 2020, at https://dx.doi.org/10.3133/ofr20151071.
Verma, M.K., and Warwick, P.D., 2011, Development of an assessment methodology for hydrocarbon recovery potential using carbon dioxide and associated carbon sequestration-Workshop findings: U.S. Geological Survey Fact Sheet 2011-3075, 2 p., accessed May 4, 2020, at https://pubs.usgs.gov/fs/2011/3075/.

Warwick, P.D., Attanasi, E.D., Blondes, M.S., Brennan, S.T., Buursink, M.L., Cahan, S.M., Doolan, C.A., Freeman, P.A., Karacan, C.Ö., Lohr, C.D., Merrill, M.D., Olea, R.A., Shelton, J.L., Slucher, E.R., and Varela, B.A., 2022a, National assessment of carbon dioxide enhanced oil recovery and associated carbon dioxide retention resources-Data: U.S. Geological Survey data release, https://doi.org/10.5066/ P9AG37KI.

Warwick, P.D., Attanasi, E.D., Blondes, M.S., Brennan, S.T., Buursink, M.L., Cahan, S.M., Doolan, C.A., Freeman, P.A., Karacan, C.Ö., Lohr, C.D., Merrill, M.D., Olea, R.A., Shelton, J.L., Slucher, E.R., and Varela, B.A., 2022b, National assessment of carbon dioxide enhanced oil recovery and associated carbon dioxide retention resources-Summary: U.S. Geological Survey Fact Sheet 2021-3057, 6 p., https://doi.org/10.3133/fs20213057.

Warwick, P.D., Attanasi, E.D., Olea, R.A., Blondes, M.S., Freeman, P.A., Brennan, S.T., Merrill, M.D., Verma, M.K., Karacan, C.Ö., Shelton, J.L., Lohr, C.D., Jahediesfanjani, H., and Roueché, J.N., 2019, A probabilistic assessment methodology for carbon dioxide enhanced oil recovery and associated carbon dioxide retention: U.S. Geological Survey Scientific Investigations Report 2019-5115, 51 p., accessed March 26, 2020, at https://doi.org/10.3133/sir20195115.

Willhite, G.P., 1986, Waterflooding: Society of Petroleum Engineers Textbook Series, v. 3, 326 p. 


\section{Glossary}

The following definitions are modified from Brennan and others (2010), U.S. Geological Survey Geologic Carbon Dioxide Storage Resources Assessment Team (2013b), Warwick and others (2019), and other sources indicated.

assessment unit code For each assessment unit, the six-digit code (shown in table 6 as the play number) identifies the USGS-specific play from the U.S. Geological Survey's 1995 National Oil and Gas Assessment (NOGA) (Beeman and others, 1996). In code 503402, for example, the first digit (5) denotes the world region, the following three digits (034) denote the North America NOGA province, and the following two digits (02) denote the play. The plays for each province are numbered $01,02,03$, and so on. The code for a province (tables 5,6 ) has four digits, such as 5034. In this report, the NOGA province and basin names are the same.

carbon dioxide $\left(\mathrm{CO}_{2}\right)$ A clear gas that is commonly found in nature and is a minor component of air (about 0.04 percent) (U.S. Department of Energy, National Energy Technology Laboratory, 2021). Carbon dioxide is the primary greenhouse gas emitted through human activities such as the combustion of fossil fuels (coal, natural gas, and oil) for energy and transportation, industrial processes, and anthropogenic land-use changes (U.S. Environmental Protection Agency, 2018).

carbon sequestration Both natural and deliberate processes by which $\mathrm{CO}_{2}$ is either removed from the atmosphere or diverted from emission sources and stored in the ocean, terrestrial environments (vegetation, soils, and sediment), and geologic formations.

$\mathrm{CO}_{2}$ Prophet A reservoir model developed for the U.S. Department of Energy by Texaco Inc. and used to determine the incremental recovery factors for oil during the $\mathrm{CO}_{2}$-EOR process, on an individual reservoir basis (Prieditis and Brugman, 1993; Dobitz and Prieditis, 1994). The model is also used to estimate the volume of $\mathrm{CO}_{2}$ remaining in the reservoir after the $\mathrm{CO}_{2}$-EOR process is complete (Attanasi, 2017; Warwick and others, 2019). continuous accumulation A petroleum accumulation that is pervasive throughout a large area, that is not significantly affected by hydrodynamic influences, and for which the chosen methodology for assessment of sizes and number of discrete accumulations is not appropriate. Continuous accumulations lack well-defined down-dip water contacts. The terms "continuous accumulation" and "continuous-type accumulation" are used interchangeably (Klett and others, 2005). Continuous accumulations are also known as unconventional accumulations.

conventional accumulation A discrete petroleum accumulation commonly bounded by a down-dip water contact and significantly affected by the buoyancy of petroleum in water. This geologic definition does not involve factors such as water depth, regulatory status, or engineering techniques (Klett and others, 2005).

Dykstra-Parsons coefficient (VDP) The Dykstra-Parsons coefficient (Dykstra and Parsons, 1950; Willhite, 1986; Lake, 1989) is a measure of the vertical reservoir heterogeneity, which is important in modeling recovery efficiency of waterfloods and $\mathrm{CO}_{2}$-EOR projects. It is calculated from permeability measurements obtained from well logs and core samples. A completely homogeneous reservoir has a Dykstra-Parsons coefficient value of 0 , whereas an infinitely heterogeneous reservoir has a Dykstra-Parsons coefficient value of 1 . For most reservoirs, the Dykstra-Parsons coefficient ranges from 0.5 to 0.9 (Willhite, 1986; Jensen and others, 1997). For this assessment methodology, the variability of $V D P$ for each reservoir was set at a fixed range of 0.51 to 0.89 .

enhanced oil recovery (EOR) Injection of steam, gas, or other chemical compounds into hydrocarbon reservoirs to stimulate the production of usable oil beyond what is possible through natural pressure, water injection, and pumping at the wellhead. In $\mathrm{CO}_{2}$-EOR, carbon dioxide gas is injected into a reservoir.

federally owned offshore areas Federal jurisdiction for offshore submerged lands begins at 3 geographic (nautical) miles from 
the established baseline for the coast and extends to an outer limit of 200 nautical miles. However, there are special cases. Because of claims existing at the dates of statehood, Texas and the Gulf Coast of Florida have a proprietary interest in a submerged belt of land, 9 geographic miles wide, extending seaward along the coast (Thormahlen, 1999). Resource assessments in federally owned offshore areas are typically performed by the Bureau of Ocean Energy Management (BOEM).

gas reservoir A subsurface accumulation of hydrocarbons primarily in the gas phase that is contained in porous or fractured rock formations. A gas reservoir in the Comprehensive Resource Database (CRD) used for this assessment methodology was defined by Carolus and others (2017, p. 13) as having greater than 10,000 standard cubic feet (scf) of natural gas per stock tank barrel (STB) of oil. This classification conforms to the demonstrated $\mathrm{CO}_{2}$-EOR projects listed in Koottungal $(2012,2014)$ and is used by some regulatory agencies to determine the primary product of hydrocarbon reservoirs (British Columbia Oil and Gas Commission, 2014). This value is lower than the 20,000 cubic feet/barrel or greater of oil used in U.S. Geological Survey (USGS) assessments of undiscovered oil and gas resources (Klett and others, 2005).

geologic storage of $\mathrm{CO}_{2}$ A type of carbon sequestration that utilizes the long-term retention of carbon dioxide in subsurface geologic formations.

gross $\mathrm{CO}_{2}$ utilization In a $\mathrm{CO}_{2}$-EOR project, gross $\mathrm{CO}_{2}$ utilization includes the total amount of $\mathrm{CO}_{2}$ injected, which incorporates both purchased and recycled $\mathrm{CO}_{2}$ volumes into the calculation (Azzolina and others, 2015).

initial oil saturation (SO) The fraction (0-1) of pore space in an oil reservoir occupied by oil prior to production.

minimum field size The lower limit for inclusion of oil and gas field information in assessment calculations. Following the USGS oil and gas assessment methodology (Schmoker and Klett, 2005), volumetric data from accumulations with less than 0.5 million barrels of oil equivalent total production were not included in any of the calculations in the methodology used for this assessment.

National Oil and Gas Assessment (NOGA) The U.S. Geological Survey Energy Resources Program provides periodic assessments of the oil and natural gas endowment of the United States and was responsible for the 1995 National Oil and Gas Assessment (NOGA) (U.S. Geological Survey National Oil and Gas Resource Assessment Team, 1995).

net carbon negative oil Approximately 300 to 600 kilograms $(\mathrm{kg})$ of $\mathrm{CO}_{2}$ are injected by $\mathrm{CO}_{2}$-EOR processes for each barrel of oil produced in the United States, although the amount of $\mathrm{CO}_{2}$ injected varies between fields and across the life of projects (McGlade, 2019). According to carbon life-cycleanalysis estimates, one barrel of oil releases around $400 \mathrm{~kg}$ of $\mathrm{CO}_{2}$ when combusted and around $100 \mathrm{~kg}$ of $\mathrm{CO}_{2}$ on average during the production, processing, and transport of the oil (McGlade, 2019). If anthropogenic $\mathrm{CO}_{2}$ captured from negative emission technologies like bioenergy electric powerplants or direct air capture is used in the $\mathrm{CO}_{2}$-EOR process, and more $\mathrm{CO}_{2}$ remains in the subsurface than is released to the atmosphere by the production, processing, transport, and combustion of the oil, then the produced oil can be described as "carbon-negative oil" (McGlade, 2019) or "net carbon negative oil" (Nuñez-López and Moskal, 2019; Nuñez-López and others, 2019). net $\mathrm{CO}_{2}$ utilization factor In a $\mathrm{CO}_{2}$-EOR project, the net $\mathrm{CO}_{2}$ utilization factor is calculated as the quantity of gross $\mathrm{CO}_{2}$ injected minus the $\mathrm{CO}_{2}$ produced divided by the oil in barrels produced. Net $\mathrm{CO}_{2}$ utilization does not include the recycled $\mathrm{CO}_{2}$ component and incorporates only the purchased $\mathrm{CO}_{2}$ volumes into the calculation (Azzolina and others, 2015).

oil reservoir A subsurface accumulation of hydrocarbons composed primarily of oil that is contained in porous or fractured rock formations. An oil reservoir in the Comprehensive Resource Database (CRD) used for this assessment methodology was defined by Carolus and others (2017, p. 13) as having less than or equal to $10,000 \mathrm{scf}$ of natural gas per STB of oil. This classification conforms to the demonstrated $\mathrm{CO}_{2}$-EOR projects listed in Koottungal $(2012,2014)$ and is used by some regulatory agencies to determine the primary product of hydrocarbon reservoirs (British Columbia Oil and Gas Commission, 2014). This value is lower than $20,000 \mathrm{scf}$ per STB of oil used in USGS assessments of undiscovered oil and gas resources (Klett and others, 2005). 
original oil in place (OOIP) The volume of original oil in a reservoir prior to production. Typically, the units are in thousands of stock tank barrels (Mbbl in STB).

percentile In values sorted by increasing magnitude, any of the 99 dividers that produce exactly 100 groups with equal number of values (Everitt and Skrondal, 2010). The dividers are used to denote the proportion of values above and below them. The dividers are sequential integer numbers starting from the one between the two groups with the lowest values. For example, in the modeling of sequestration capacity, a 95th percentile of 10 gigatons (Gt) denotes that $10 \mathrm{Gt}$ divides all likely values into 95 percent of them equal to or below $10 \mathrm{Gt}$ and 5 percent above it.

permeability ( $\boldsymbol{k})$ A measure of the ability of a rock to permit fluids to be transmitted through it; permeability is controlled by pore size, pore throat geometry, and pore connectivity. Permeability is typically reported in darcies or millidarcies.

play A set of known or postulated oil and (or) gas accumulations sharing similar geologic, geographic, and temporal properties, such as source rock, migration patterns, timing, trapping mechanism, and hydrocarbon type. Confirmed plays are plays where one or more accumulations of minimum size ( 1 million barrels of oil or 6 billion cubic feet of gas) have been discovered in the play (U.S. Geological Survey National Oil and Gas Resource Assessment Team, 1995; Klett and others, 2005). Since 2000, the U.S. Geological Survey Energy Resources Program oil and gas assessments have used subdivisions of the total petroleum system, termed assessment units, as the basic level of assessment. A total petroleum system consists of all genetically related petroleum generated by a pod or closely related pods of mature source rocks (Schmoker and Klett, 2005, p. 5).

porosity (Ø) The part of a rock that is occupied by voids or pores. Pores can be connected by passages called pore throats, which allow for fluid flow, or pores can be isolated and inaccessible to fluid flow. These conditions can be overcome by hydraulic fracture stimulation wherein the pores are forcibly connected with high-pressure fluid injection and propping open of the induced fracture.
Porosity is typically reported as a volume, fraction, or percentage of the rock.

primary production After discovery, an oilfield is initially developed and produced using primary production mechanisms in which natural reservoir energy - expansion of dissolved gases, change in rock volume, gravity, and aquifer influx - drive the hydrocarbon fluids from the reservoir to the wellbores as pressure declines with fluid (oil, water, or gas) production. Primary oil recoveries range between 5 and 20 percent (Stalkup, 1983) of the original oil in place (OOIP) (Verma, 2015, p. 2).

residual oil zone (ROZ) The interval of the reservoir below the oil-water contact where oil saturation varies from its highest value in the upper section to almost approaching zero percent at the base of the interval.

secondary production Secondary production methods entail injecting water and (or) natural gas into the reservoir for repressurizing and (or) pressure maintenance and to potentially act as a water and (or) gas drive to displace oil. This helps to sustain higher production rates and extends the productive life of the reservoir. Normal practice has been to inject natural gas into the gas cap or at the top of the reservoir and inject water below the oil-water contact. The oil recoveries at the end of both the primary and secondary recovery phases are generally in the range of 20-40 percent of the OOIP, although in some cases, recoveries could be lower or higher (Stalkup, 1983). Tzimas and others (2005) have reported a slightly higher recovery range of 35-45 percent of OOIP at the end of secondary recovery in their study of North Sea oil reservoirs (Verma, 2015, p. 2).

State waters State jurisdiction begins at the established baseline for the coast and extends seaward 3 geographic (nautical) miles. However, there are special cases. Because of claims existing at the dates of statehood, Texas and the Gulf Coast of Florida have a proprietary interest in a submerged belt of land, 9 geographic miles wide, extending seaward along the coast (Thormahlen, 1999).

trapping The physical and geochemical processes by which injected $\mathrm{CO}_{2}$ is retained in the subsurface. 



\section{Table 6. Estimated volume of oil that could be produced with carbon dioxide enhanced oil recovery $\left(\mathrm{CO}_{2}\right.$-EOR) and estimated mass of associated carbon dioxide $\left(\mathrm{CO}_{2}\right)$ that could be stored (retained) in existing reservoirs underlying onshore and State waters areas of the conterminous United States, aggregated by province and play}

Estimates of volumes of oil that could be produced with $\mathrm{CO}_{2}-\mathrm{EOR}$ are in millions of petroleum barrels (MMbbl), and estimates of the mass of associated $\mathrm{CO}_{2}$ that could be stored (retained) are in millions of metric tons (Mt).

$P_{5^{\prime}} P_{50^{\prime}}$ and $P_{95}$ are probability percentiles and represent the 5-, 50-, and 95-percent probabilities, respectively, that the true resource is less than or equal to the value shown. The terminology used in this report differs from that used by the petroleum industry and follows standard statistical practice (for example, Everitt and Skrondal, 2010), where percentiles, or fractiles, represent the value of a variable below which a certain proportion of observations falls. The percentiles were calculated by using the aggregation method described in U.S. Geological Survey Geologic Carbon Dioxide Storage Resources Assessment Team (2013b) and in Blondes, Schuenemeyer, and others (2013). Percentile values do not sum to totals because the aggregation procedure used partial dependencies between assessment units. The $P_{50}$ (median) values may be less than mean values because most output distributions are right skewed.

Values are reported to only two significant figures, and mean entries may not sum to totals because of rounding. Four- and six-digit codes identify the USGS-specific province and play, respectively. Components of the assessment unit code (play number) are explained in the "Glossary." Resources in Alaska, Hawaii, and federally owned offshore areas were not assessed. 
Table 6. Estimated volume of oil that could be produced with carbon dioxide enhanced oil recovery $\left(\mathrm{CO}_{2}\right.$-EOR) and estimated mass of associated carbon dioxide $\left(\mathrm{CO}_{2}\right)$ that could be stored (retained) in existing reservoirs underlying onshore and State waters areas of the conterminous United States, aggregated by province and play.

[MMbbl, millions of petroleum barrels; $M t$, millions of metric tons. Probability percentiles $\left(P_{5^{\prime}}, P_{50}\right.$ and $\left.P_{95}\right)$ are defined on p. 29]

\begin{tabular}{|c|c|c|c|c|c|c|c|c|c|}
\hline $\begin{array}{c}\text { Play } \\
\text { number }\end{array}$ & Play name & $\mathbf{P}_{5}$ & $\mathbf{P}_{50}$ & $\mathbf{P}_{95}$ & Mean & $\mathbf{P}_{5}$ & $\mathbf{P}_{50}$ & $\mathbf{P}_{95}$ & Mean \\
\hline 500903 & $\begin{array}{l}\text { Western Winters through } \\
\text { Domengine }\end{array}$ & 6.7 & 8.7 & 11 & 8.7 & 1.7 & 2.2 & 2.7 & 2.2 \\
\hline 501002 & Southeast Stable Shelf & 5.8 & 7.3 & 8.8 & 7.3 & 1.5 & 1.9 & 2.3 & 1.9 \\
\hline 501003 & Lower Bakersfield Arch & 210 & 260 & 310 & 260 & 61 & 76 & 90 & 76 \\
\hline 501004 & $\begin{array}{l}\text { West Side Fold Belt } \\
\text { Sourced by Post-Lower } \\
\text { Miocene Rocks }\end{array}$ & 34 & 43 & 51 & 43 & 8.6 & 11 & 13 & 11 \\
\hline 501006 & $\begin{array}{l}\text { Northeast Shelf of Neogene } \\
\text { Basin }\end{array}$ & 11 & 14 & 18 & 14 & 2.6 & 3.5 & 4.5 & 3.5 \\
\hline 501007 & $\begin{array}{l}\text { Northern Area Non- } \\
\text { associated Gas }\end{array}$ & 1.8 & 2.4 & 2.9 & 2.3 & 0.49 & 0.64 & 0.77 & 0.63 \\
\hline 501008 & Tejon Platform & 38 & 47 & 56 & 47 & 11 & 14 & 16 & 14 \\
\hline & Aggregated total & 690 & 850 & 1,000 & 850 & 190 & 230 & 270 & 230 \\
\hline \multicolumn{10}{|c|}{ Central Coastal (5011) } \\
\hline \multirow[t]{2}{*}{501107} & Western Cuyama Basin & 5.0 & 6.5 & 8.0 & 6.5 & 1.1 & 1.5 & 1.8 & 1.5 \\
\hline & Aggregated total & 5.0 & 6.5 & 8.0 & 6.5 & 1.1 & 1.5 & 1.8 & 1.5 \\
\hline 501401 & $\begin{array}{l}\text { Santa Monica Fault System } \\
\text { and Las Cienegas Fault } \\
\text { and Block }\end{array}$ & 58 & 73 & 89 & 73 & 16 & 21 & 25 & 21 \\
\hline 501403 & $\begin{array}{l}\text { Newport-Inglewood } \\
\text { Deformation Zone and } \\
\text { Southwestern Flank of } \\
\text { Central Syncline }\end{array}$ & 140 & 170 & 200 & 170 & 36 & 44 & 51 & 43 \\
\hline 501404 & $\begin{array}{l}\text { Whittier Fault Zone and } \\
\text { Fullerton Embayment }\end{array}$ & 330 & 420 & 500 & 420 & 79 & 99 & 120 & 99 \\
\hline 501405 & $\begin{array}{l}\text { Northern Shelf and } \\
\text { Northern Flank of } \\
\text { Central Syncline }\end{array}$ & 77 & 99 & 120 & 99 & 17 & 22 & 27 & 22 \\
\hline & Aggregated total & 620 & 760 & 890 & 760 & 150 & 190 & 220 & 190 \\
\hline
\end{tabular}


Table 6. Estimated volume of oil that could be produced with carbon dioxide enhanced oil recovery $\left(\mathrm{CO}_{2}\right.$-EOR) and estimated mass of associated carbon dioxide $\left(\mathrm{CO}_{2}\right)$ that could be stored (retained) in existing reservoirs underlying onshore and State waters areas of the conterminous United States, aggregated by province and play.-Continued

[MMbbl, millions of petroleum barrels; $M t$, millions of metric tons. Probability percentiles $\left(P_{5}, P_{50^{\prime}}\right.$ and $\left.P_{95}\right)$ are defined on p. 29]

\begin{tabular}{|c|c|c|c|c|c|c|c|c|c|}
\hline \multirow{2}{*}{$\begin{array}{c}\text { Play } \\
\text { number }\end{array}$} & \multirow{2}{*}{ Play name } & \multicolumn{4}{|c|}{ Oil produced with $\mathrm{CO}_{2}-\mathrm{EOR}$ (MMbbl) } & \multicolumn{4}{|c|}{$\mathrm{CO}_{2}$ retention with $\mathrm{CO}_{2}-\mathrm{EOR}(\mathrm{Mt})$} \\
\hline & & $\mathbf{P}_{5}$ & $\mathbf{P}_{50}$ & $\mathbf{P}_{95}$ & Mean & $P_{5}$ & $\mathbf{P}_{50}$ & $\mathbf{P}_{95}$ & Mean \\
\hline 502002 & Uinta Tertiary Oil and Gas & 240 & 240 & 240 & 240 & 76 & 100 & 130 & 100 \\
\hline 502005 & $\begin{array}{l}\text { Permian-Pennsylvanian } \\
\text { Sandstones and } \\
\text { Carbonates }\end{array}$ & 6.4 & 8.4 & 10 & 8.4 & 1.6 & 2.1 & 2.6 & 2.1 \\
\hline & Aggregated total & 240 & 320 & 400 & 320 & 78 & 100 & 130 & 100 \\
\hline \multicolumn{10}{|c|}{ Paradox Basin (5021) } \\
\hline 502102 & Porous Carbonate Buildup & 38 & 49 & 59 & 49 & 12 & 15 & 19 & 16 \\
\hline 502106 & $\begin{array}{l}\text { Permo-Triassic } \\
\text { Unconformity }\end{array}$ & 13 & 17 & 21 & 17 & 3.8 & 5.0 & 6.2 & 5.0 \\
\hline 502206 & Basin Margin Dakota Oil & 3.3 & 4.4 & 5.4 & 4.4 & 0.98 & 1.3 & 1.6 & 1.3 \\
\hline \multirow[t]{2}{*}{502207} & Tocito/Gallup Sandstone Oil & 380 & 520 & 680 & 520 & 100 & 140 & 180 & 140 \\
\hline & Aggregated total & 380 & 530 & 690 & 530 & 100 & 140 & 180 & 140 \\
\hline \multicolumn{10}{|c|}{ North-Central Montana (5028) } \\
\hline 502805 & $\begin{array}{l}\text { Devonian-Mississippian } \\
\text { Carbonates }\end{array}$ & 28 & 36 & 44 & 36 & 7.7 & 10 & 12 & 10 \\
\hline 502806 & Tyler Sandstone & 19 & 23 & 28 & 23 & 4.7 & 5.9 & 7.0 & 5.9 \\
\hline 502808 & $\begin{array}{l}\text { Jurassic-Cretaceous } \\
\text { Sandstones }\end{array}$ & 11 & 14 & 17 & 14 & 2.8 & 3.6 & 4.4 & 3.6 \\
\hline 503105 & $\begin{array}{l}\text { Pre-Prairie Middle } \\
\text { Devonian and Silurian }\end{array}$ & 150 & 190 & 230 & 190 & 47 & 60 & 73 & 60 \\
\hline 503106 & $\begin{array}{l}\text { Post-Madison through } \\
\text { Triassic Clastics }\end{array}$ & 51 & 65 & 79 & 65 & 14 & 18 & 22 & 18 \\
\hline 503107 & Pre-Red River Gas & 0.50 & 0.72 & 0.99 & 0.73 & 0.18 & 0.27 & 0.37 & 0.27 \\
\hline & Aggregated total & 1,100 & 1,300 & 1,600 & 1,300 & 370 & 460 & 560 & 460 \\
\hline \multicolumn{10}{|c|}{ Powder River Basin (5033) } \\
\hline 503302 & Basin Margin Anticline & 79 & 100 & 120 & 100 & 20 & 26 & 31 & 26 \\
\hline 503304 & $\begin{array}{l}\text { Upper Minnelusa } \\
\text { Sandstone }\end{array}$ & 120 & 140 & 170 & 140 & 32 & 40 & 47 & 40 \\
\hline 503306 & Fall River Sandstone & 44 & 55 & 66 & 55 & 12 & 15 & 18 & 15 \\
\hline 503307 & Muddy Sandstone & 160 & 200 & 240 & 200 & 52 & 64 & 76 & 64 \\
\hline
\end{tabular}


Table 6. Estimated volume of oil that could be produced with carbon dioxide enhanced oil recovery $\left(\mathrm{CO}_{2}\right.$-EOR) and estimated mass of associated carbon dioxide $\left(\mathrm{CO}_{2}\right)$ that could be stored (retained) in existing reservoirs underlying onshore and State waters areas of the conterminous United States, aggregated by province and play.-Continued

[MMbbl, millions of petroleum barrels; $M t$, millions of metric tons. Probability percentiles $\left(P_{5^{\prime}}, P_{50}\right.$ and $\left.P_{95}\right)$ are defined on p. 29]

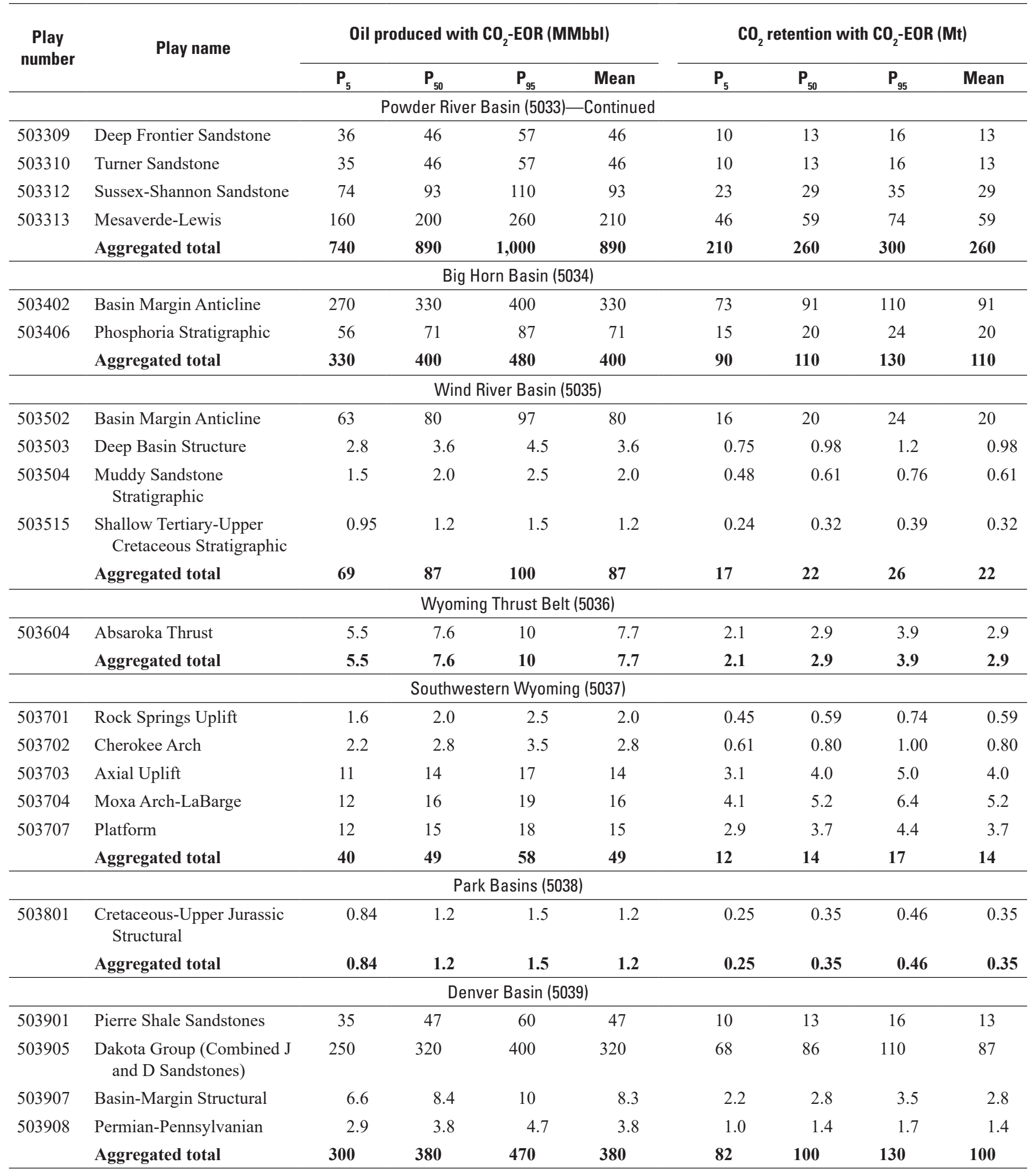


Table 6. Estimated volume of oil that could be produced with carbon dioxide enhanced oil recovery $\left(\mathrm{CO}_{2}\right.$-EOR) and estimated mass of associated carbon dioxide $\left(\mathrm{CO}_{2}\right)$ that could be stored (retained) in existing reservoirs underlying onshore and State waters areas of the conterminous United States, aggregated by province and play.-Continued

[MMbbl, millions of petroleum barrels; $M t$, millions of metric tons. Probability percentiles $\left(P_{5}, P_{50^{\prime}}\right.$ and $\left.P_{95}\right)$ are defined on p. 29]

\begin{tabular}{|c|c|c|c|c|c|c|c|c|c|}
\hline \multirow{2}{*}{$\begin{array}{c}\text { Play } \\
\text { number }\end{array}$} & \multirow{2}{*}{ Play name } & \multicolumn{4}{|c|}{ Oil produced with $\mathrm{CO}_{2}-\mathrm{EOR}$ (MMbbl) } & \multicolumn{4}{|c|}{$\mathrm{CO}_{2}$ retention with $\mathrm{CO}_{2}-\mathrm{EOR}(\mathrm{Mt})$} \\
\hline & & $\mathbf{P}_{5}$ & $\mathbf{P}_{50}$ & $\mathbf{P}_{95}$ & Mean & $\mathbf{P}_{5}$ & $\mathbf{P}_{50}$ & $\mathbf{P}_{95}$ & Mean \\
\hline 504004 & $\begin{array}{l}\text { Lower Pennsylvanian } \\
\text { (Morrowan) Sandstone } \\
\text { Oil, Gas, and Natural } \\
\text { Gas Liquids }\end{array}$ & 1.3 & 1.7 & 2.1 & 1.7 & 0.47 & 0.61 & 0.74 & 0.61 \\
\hline 504005 & Mississippian Carbonate & 21 & 27 & 33 & 27 & 6.3 & 8.0 & 9.8 & 8.0 \\
\hline & Aggregated total & 23 & 29 & 35 & 29 & 6.9 & 8.6 & 10 & 8.6 \\
\hline \multicolumn{10}{|c|}{ Permian Basin (5044) } \\
\hline 504401 & $\begin{array}{l}\text { Pre-Pennsylvanian, } \\
\text { Delaware-Val Verde } \\
\text { Basins }\end{array}$ & 4.3 & 5.7 & 7.1 & 5.7 & 1.5 & 2.0 & 2.5 & 2.0 \\
\hline 504403 & $\begin{array}{l}\text { Pre-Pennsylvanian, } \\
\text { Northwestern and } \\
\text { Eastern Shelves }\end{array}$ & 260 & 340 & 430 & 340 & 83 & 110 & 140 & 110 \\
\hline 504404 & $\begin{array}{l}\text { Lower Pennsylvanian } \\
\text { (Bend) Sandstone }\end{array}$ & 61 & 79 & 98 & 79 & 17 & 22 & 28 & 22 \\
\hline 504405 & $\begin{array}{l}\text { Horseshoe Atoll, Upper } \\
\text { Pennsylvanian- } \\
\text { Wolfcampian }\end{array}$ & 340 & 430 & 520 & 430 & 110 & 140 & 170 & 140 \\
\hline 504406 & $\begin{array}{l}\text { Upper Pennsylvanian, } \\
\text { Northwestern and } \\
\text { Eastern Shelves, } \\
\text { Northern Delaware and } \\
\text { Midland Basins and } \\
\text { Northern Central Basin } \\
\text { Platform }\end{array}$ & 730 & 940 & 1,200 & 940 & 230 & 300 & 370 & 300 \\
\hline 504408 & $\begin{array}{l}\text { Wolfcampian Carbonate, } \\
\text { Eastern and Southern } \\
\text { Margins of the Central } \\
\text { Basin Platform }\end{array}$ & 210 & 270 & 330 & 270 & 69 & 87 & 110 & 87 \\
\hline 504409 & Spraberry-Dean & 290 & 370 & 440 & 370 & 99 & 130 & 150 & 130 \\
\hline 504410 & $\begin{array}{l}\text { San Andres-Clearfork, } \\
\text { Central Basin Platform } \\
\text { and Ozona Arch }\end{array}$ & 2,500 & 3,100 & 3,700 & 3,100 & 780 & 980 & 1,200 & 980 \\
\hline 504411 & $\begin{array}{c}\text { San Andres-Clearfork, } \\
\text { Northwestern and } \\
\text { Eastern Shelves }\end{array}$ & 2,200 & 2,800 & 3,600 & 2,900 & 650 & 850 & 1,100 & 860 \\
\hline \multirow[t]{2}{*}{504412} & Delaware Sandstones & 740 & 940 & 1,100 & 940 & 240 & 310 & 380 & 310 \\
\hline & Aggregated total & 8,600 & 11,000 & 13,000 & 11,000 & 2,700 & 3,300 & 3,900 & 3,300 \\
\hline
\end{tabular}


Table 6. Estimated volume of oil that could be produced with carbon dioxide enhanced oil recovery $\left(\mathrm{CO}_{2}\right.$ - $\left.\mathrm{EOR}\right)$ and estimated mass of associated carbon dioxide $\left(\mathrm{CO}_{2}\right)$ that could be stored (retained) in existing reservoirs underlying onshore and State waters areas of the conterminous United States, aggregated by province and play.-Continued

[MMbbl, millions of petroleum barrels; $M t$, millions of metric tons. Probability percentiles $\left(P_{5^{\prime}}, P_{50}\right.$ and $\left.P_{95}\right)$ are defined on p. 29]

\begin{tabular}{|c|c|c|c|c|c|c|c|c|c|}
\hline \multirow{2}{*}{$\begin{array}{c}\text { Play } \\
\text { number }\end{array}$} & \multirow{2}{*}{ Play name } & \multicolumn{4}{|c|}{ Oil produced with $\mathrm{CO}_{2}$-EOR (MMbbl) } & \multicolumn{4}{|c|}{$\mathrm{CO}_{2}$ retention with $\mathrm{CO}_{2}-\mathrm{EOR}(\mathrm{Mt})$} \\
\hline & & $\mathbf{P}_{5}$ & $\mathbf{P}_{50}$ & $\mathbf{P}_{95}$ & Mean & $\mathbf{P}_{5}$ & $\mathbf{P}_{50}$ & $\mathbf{P}_{95}$ & Mean \\
\hline \multicolumn{10}{|c|}{ Bend Arch-Fort Worth Basin (5045) } \\
\hline 504501 & $\begin{array}{l}\text { Pre-Mississippian } \\
\text { Carbonate }\end{array}$ & 52 & 74 & 100 & 74 & 16 & 23 & 31 & 23 \\
\hline 504502 & Mississippian Carbonate & 100 & 130 & 170 & 140 & 31 & 40 & 51 & 41 \\
\hline 504504 & $\begin{array}{l}\text { Lower Pennsylvanian } \\
\text { (Bend) Sandstone and } \\
\text { Conglomerate }\end{array}$ & 170 & 220 & 260 & 220 & 54 & 68 & 82 & 68 \\
\hline 504505 & Strawn (Desmoinesian) & 620 & 780 & 940 & 780 & 170 & 220 & 260 & 220 \\
\hline \multirow[t]{2}{*}{504506} & Post-Desmoinesian & 59 & 75 & 91 & 75 & 16 & 20 & 25 & 20 \\
\hline & Aggregated total & 1,000 & 1,300 & 1,500 & 1,300 & 300 & 370 & 440 & 370 \\
\hline \multicolumn{10}{|c|}{ Western Gulf (5047) } \\
\hline 504701 & $\begin{array}{l}\text { Houston Salt Dome Flank } \\
\text { Oil and Gas }\end{array}$ & 490 & 600 & 710 & 600 & 120 & 140 & 170 & 140 \\
\hline 504705 & $\begin{array}{l}\text { Lower Cretaceous } \\
\text { Carbonate Shelf/Shelf } \\
\text { Edge Gas and Oil }\end{array}$ & 48 & 63 & 79 & 63 & 17 & 22 & 28 & 22 \\
\hline 504708 & Buda Downdip Oil & 2.1 & 3.1 & 4.2 & 3.1 & 0.74 & 1.1 & 1.4 & 1.1 \\
\hline 504710 & $\begin{array}{l}\text { Woodbine South Angelina } \\
\text { Flexure Oil and Gas }\end{array}$ & 32 & 40 & 48 & 40 & 10 & 12 & 15 & 12 \\
\hline 504715 & $\begin{array}{l}\text { Upper Cretaceous } \\
\text { Sandstones Fault Zone } \\
\text { Oil }\end{array}$ & 14 & 17 & 21 & 17 & 3.6 & 4.5 & 5.4 & 4.5 \\
\hline 504716 & $\begin{array}{l}\text { Upper Cretaceous } \\
\text { Sandstones Maverick } \\
\text { Basin Oil }\end{array}$ & 25 & 32 & 40 & 32 & 7 & 8.6 & 11 & 8.6 \\
\hline 504719 & $\begin{array}{l}\text { Lower Wilcox Fluvial Oil } \\
\text { and Gas }\end{array}$ & 22 & 30 & 38 & 30 & 5.0 & 6.6 & 8.5 & 6.7 \\
\hline 504722 & $\begin{array}{l}\text { Upper Wilcox Shelf-Edge } \\
\text { Gas and Oil }\end{array}$ & 67 & 86 & 100 & 86 & 20 & 26 & 32 & 26 \\
\hline 504724 & $\begin{array}{l}\text { Middle Eocene Sandstones } \\
\text { Downdip Gas }\end{array}$ & 2.1 & 2.8 & 3.7 & 2.9 & 0.58 & 0.79 & 1.0 & 0.79 \\
\hline 504725 & $\begin{array}{l}\text { Middle Eocene Sandstones } \\
\text { Updip Fluvial Oil and Gas }\end{array}$ & 23 & 29 & 36 & 29 & 6.2 & 7.8 & 9.5 & 7.8 \\
\hline 504726 & $\begin{array}{l}\text { Yegua Updip Fluvial- } \\
\text { Deltaic Oil and Gas }\end{array}$ & 68 & 86 & 110 & 86 & 17 & 22 & 27 & 22 \\
\hline 504728 & Jackson Updip Gas and Oil & 6.5 & 8.3 & 9.9 & 8.2 & 1.6 & 2.0 & 2.4 & 2.0 \\
\hline 504730 & Vicksburg Updip Gas & 3.7 & 4.9 & 6.1 & 4.9 & 0.9 & 1.2 & 1.5 & 1.2 \\
\hline 504731 & Vicksburg Downdip Gas & 5.4 & 7.0 & 8.5 & 7.0 & 1.5 & 1.9 & 2.3 & 1.9 \\
\hline 504732 & $\begin{array}{c}\text { Frio South Texas } \\
\text { Downdip Gas }\end{array}$ & 0.59 & 0.77 & 0.93 & 0.76 & 0.17 & 0.23 & 0.27 & 0.22 \\
\hline 504733 & $\begin{array}{l}\text { Frio South Texas Mid-Dip } \\
\text { Oil and Gas }\end{array}$ & 200 & 250 & 300 & 250 & 50 & 63 & 74 & 62 \\
\hline
\end{tabular}


Table 6. Estimated volume of oil that could be produced with carbon dioxide enhanced oil recovery $\left(\mathrm{CO}_{2}\right.$ - $\left.E \mathrm{ER}\right)$ and estimated mass of associated carbon dioxide $\left(\mathrm{CO}_{2}\right)$ that could be stored (retained) in existing reservoirs underlying onshore and State waters areas of the conterminous United States, aggregated by province and play.-Continued

[MMbbl, millions of petroleum barrels; $M t$, millions of metric tons. Probability percentiles $\left(P_{5^{\prime}}, P_{50^{\prime}}\right.$ and $\left.P_{95}\right)$ are defined on p. 29]

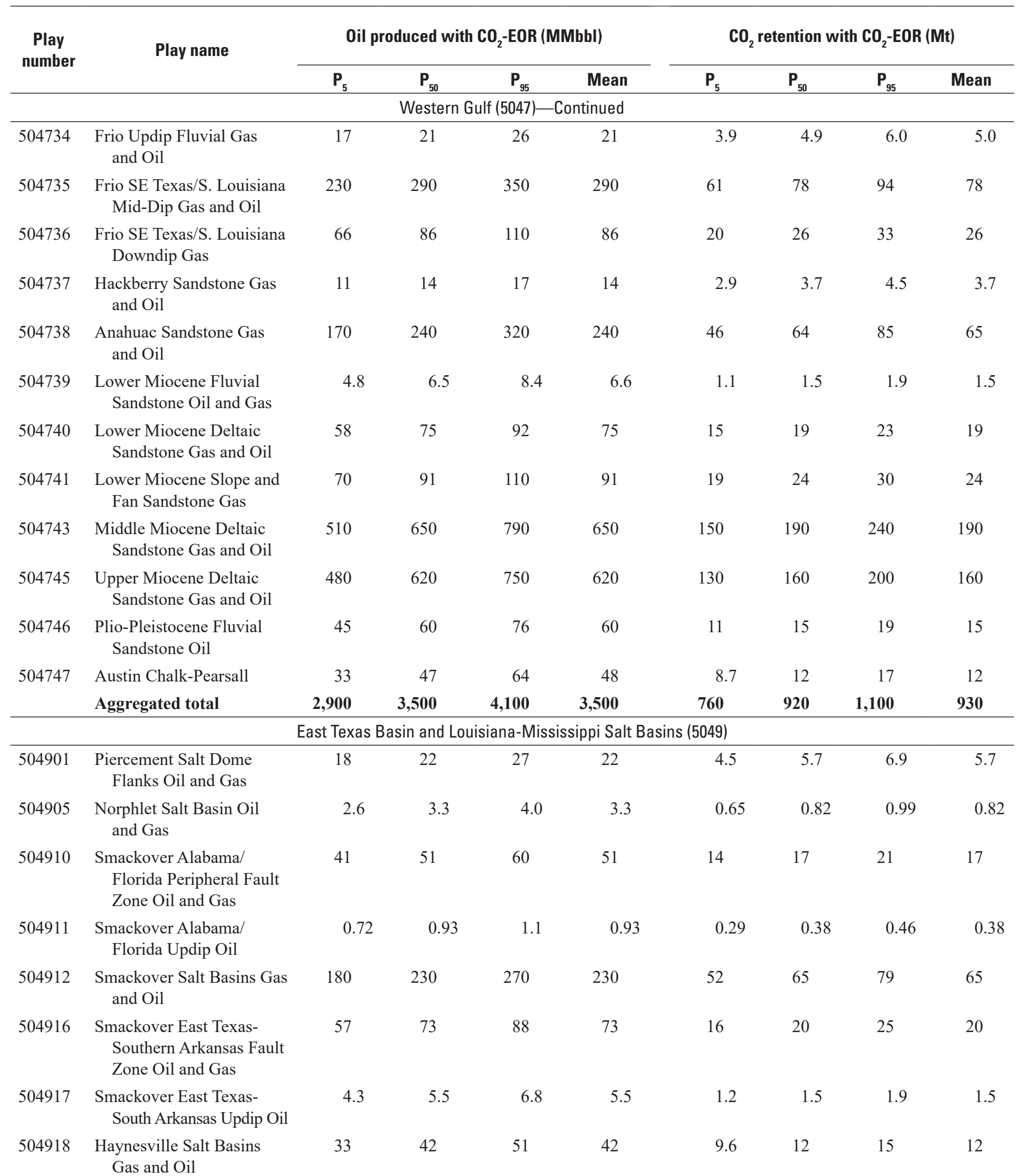


Table 6. Estimated volume of oil that could be produced with carbon dioxide enhanced oil recovery $\left(\mathrm{CO}_{2}\right.$-EOR) and estimated mass of associated carbon dioxide $\left(\mathrm{CO}_{2}\right)$ that could be stored (retained) in existing reservoirs underlying onshore and State waters areas of the conterminous United States, aggregated by province and play.-Continued

[MMbbl, millions of petroleum barrels; Mt, millions of metric tons. Probability percentiles $\left(P_{5^{\prime}}, P_{50}\right.$, and $\left.P_{95}\right)$ are defined on p. 29]

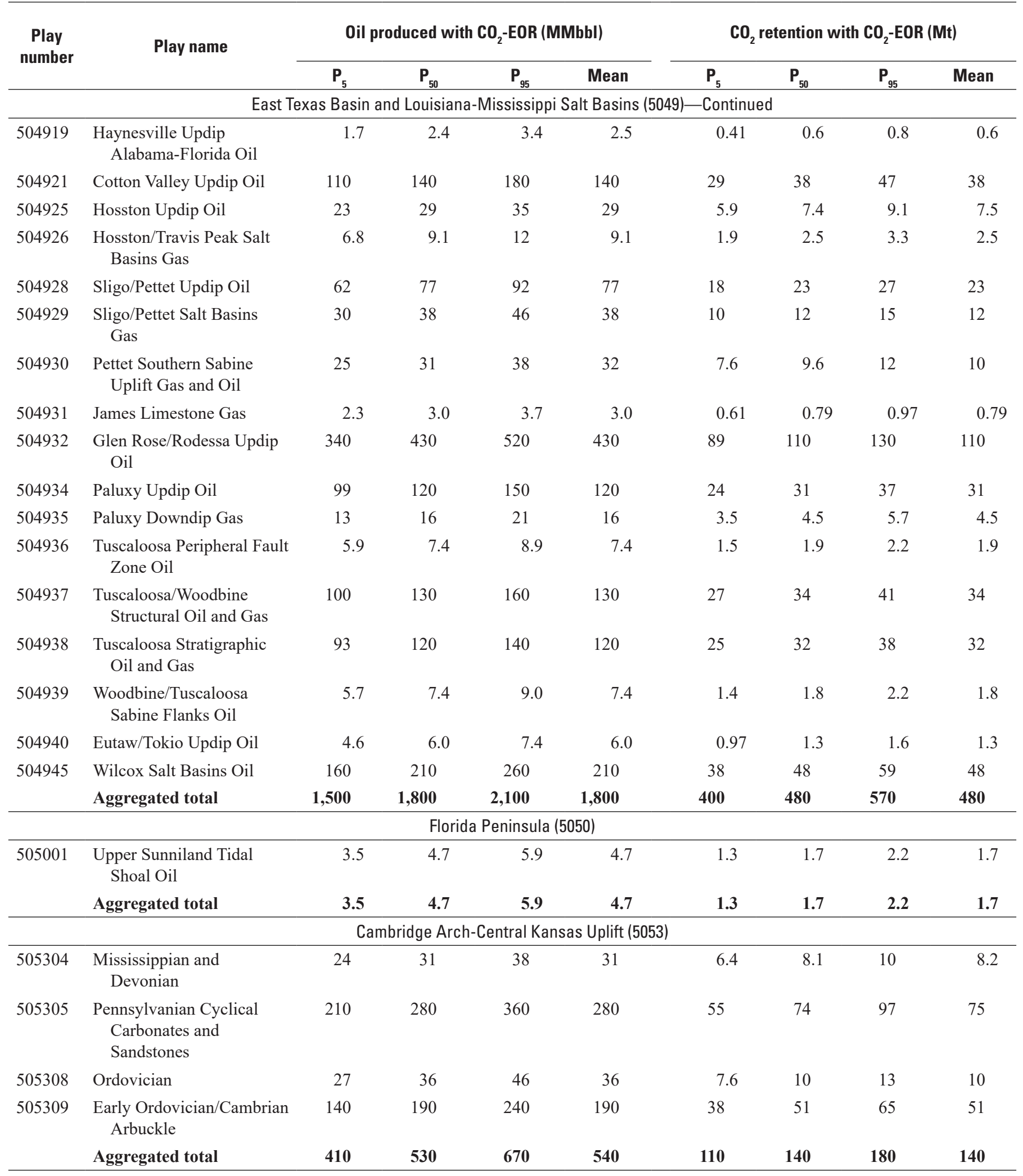


Table 6. Estimated volume of oil that could be produced with carbon dioxide enhanced oil recovery $\left(\mathrm{CO}_{2}\right.$ - $\left.\mathrm{EOR}\right)$ and estimated mass of associated carbon dioxide $\left(\mathrm{CO}_{2}\right)$ that could be stored (retained) in existing reservoirs underlying onshore and State waters areas of the conterminous United States, aggregated by province and play.-Continued

[MMbbl, millions of petroleum barrels; $M t$, millions of metric tons. Probability percentiles $\left(P_{5}, P_{50^{\prime}}\right.$ and $\left.P_{95}\right)$ are defined on p. 29]

\begin{tabular}{|c|c|c|c|c|c|c|c|c|c|}
\hline \multirow{2}{*}{$\begin{array}{c}\text { Play } \\
\text { number }\end{array}$} & \multirow{2}{*}{ Play name } & \multicolumn{4}{|c|}{ Oil produced with $\mathrm{CO}_{2}-\mathrm{EOR}(\mathrm{MMbbl})$} & \multicolumn{4}{|c|}{$\mathrm{CO}_{2}$ retention with $\mathrm{CO}_{2}-\mathrm{EOR}(\mathrm{Mt})$} \\
\hline & & $\mathbf{P}_{5}$ & $\mathbf{P}_{50}$ & $\mathbf{P}_{95}$ & Mean & $\mathbf{P}_{5}$ & $\mathbf{P}_{50}$ & $\mathbf{P}_{95}$ & Mean \\
\hline \multicolumn{10}{|c|}{ Nemaha Uplift (5055) } \\
\hline 505501 & Pre-Woodford Paleozoic & 280 & 390 & 530 & 390 & 79 & 110 & 150 & 110 \\
\hline 505503 & Mississippian & 110 & 140 & 190 & 150 & 30 & 40 & 52 & 40 \\
\hline 505504 & $\begin{array}{l}\text { Pennsylvanian-Permian } \\
\text { Structural }\end{array}$ & 130 & 180 & 240 & 180 & 43 & 59 & 79 & 59 \\
\hline 505505 & $\begin{array}{l}\text { Pennsylvanian } \\
\text { Stratigraphic }\end{array}$ & 120 & 150 & 200 & 150 & 27 & 36 & 46 & 37 \\
\hline & Aggregated total & 660 & 870 & 1,100 & 870 & 190 & 250 & 320 & 250 \\
\hline \multicolumn{10}{|c|}{ Anadarko Basin (5058) } \\
\hline 505801 & Deep Structural Gas & 18 & 25 & 36 & 26 & 6.0 & 8.6 & 12 & 8.8 \\
\hline 505802 & Uppermost Arbuckle & 6.1 & 8.9 & 12 & 9.0 & 1.6 & 2.4 & 3.3 & 2.4 \\
\hline 505804 & Wichita Mountains Uplift & 19 & 27 & 38 & 28 & 5.3 & 7.6 & 10 & 7.7 \\
\hline 505805 & Simpson Oil and Gas & 8 & 11 & 14 & 11 & 2.3 & 3.1 & 4 & 3.1 \\
\hline 505809 & $\begin{array}{l}\text { Hunton Stratigraphic- } \\
\text { Unconformity Gas } \\
\text { and Oil }\end{array}$ & 18 & 24 & 31 & 24 & 4.2 & 5.6 & 7 & 5.6 \\
\hline 505810 & Misener Oil & 20 & 26 & 32 & 26 & 6.3 & 8.1 & 10 & 8.2 \\
\hline 505812 & Deep Stratigraphic Gas & 2.4 & 3.4 & 4.5 & 3.4 & 0.81 & 1.1 & 2 & 1.2 \\
\hline 505813 & $\begin{array}{l}\text { Lower Mississippian } \\
\text { Stratigraphic Oil } \\
\text { and Gas }\end{array}$ & 120 & 210 & 320 & 210 & 36 & 60 & 94 & 62 \\
\hline 505814 & $\begin{array}{l}\text { Upper Mississippian } \\
\text { Stratigraphic Gas and Oil }\end{array}$ & 45 & 61 & 78 & 61 & 14 & 19 & 24 & 19 \\
\hline 505815 & $\begin{array}{l}\text { Springer Stratigraphic Gas } \\
\text { and Oil }\end{array}$ & 2.5 & 3.4 & 4.4 & 3.4 & 0.75 & 1.0 & 1.3 & 1.0 \\
\hline 505816 & $\begin{array}{l}\text { Morrow Sandstone Gas and } \\
\text { Oil Stratigraphic }\end{array}$ & 190 & 260 & 330 & 260 & 55 & 73 & 95 & 74 \\
\hline 505819 & $\begin{array}{l}\text { Lower Desmoinesian } \\
\text { Stratigraphic Gas } \\
\text { and Oil }\end{array}$ & 55 & 74 & 96 & 74 & 16 & 21 & 28 & 22 \\
\hline 505820 & $\begin{array}{l}\text { Upper Desmoinesian Oil } \\
\text { and Gas }\end{array}$ & 120 & 160 & 210 & 170 & 38 & 51 & 65 & 51 \\
\hline 505821 & $\begin{array}{l}\text { Lower Missourian } \\
\text { Stratigraphic Oil and Gas }\end{array}$ & 74 & 98 & 130 & 98 & 25 & 33 & 43 & 33 \\
\hline 505822 & $\begin{array}{l}\text { Upper Missourian Oil } \\
\text { and Gas }\end{array}$ & 44 & 61 & 82 & 62 & 13 & 18 & 24 & 18 \\
\hline 505823 & $\begin{array}{l}\text { Lower Virgilian Sandstone } \\
\text { Gas and Oil }\end{array}$ & 51 & 65 & 78 & 65 & 17 & 21 & 26 & 21 \\
\hline 505824 & $\begin{array}{l}\text { Upper Virgilian } \\
\text { Stratigraphic Oil and Gas }\end{array}$ & 17 & 23 & 30 & 23 & 5.0 & 6.7 & 8.7 & 6.8 \\
\hline \multirow[t]{2}{*}{505827} & Washes & 7.5 & 10 & 13 & 10 & 2.5 & 3.3 & 4.2 & 3.3 \\
\hline & Aggregated total & 890 & 1,200 & 1,500 & 1,200 & 270 & 350 & 440 & 350 \\
\hline
\end{tabular}


Table 6. Estimated volume of oil that could be produced with carbon dioxide enhanced oil recovery $\left(\mathrm{CO}_{2}\right.$-EOR) and estimated mass of associated carbon dioxide $\left(\mathrm{CO}_{2}\right)$ that could be stored (retained) in existing reservoirs underlying onshore and State waters areas of the conterminous United States, aggregated by province and play.-Continued

[MMbbl, millions of petroleum barrels; $M t$, millions of metric tons. Probability percentiles $\left(P_{5^{\prime}} P_{50^{\prime}}\right.$ and $\left.P_{95}\right)$ are defined on p. 29]

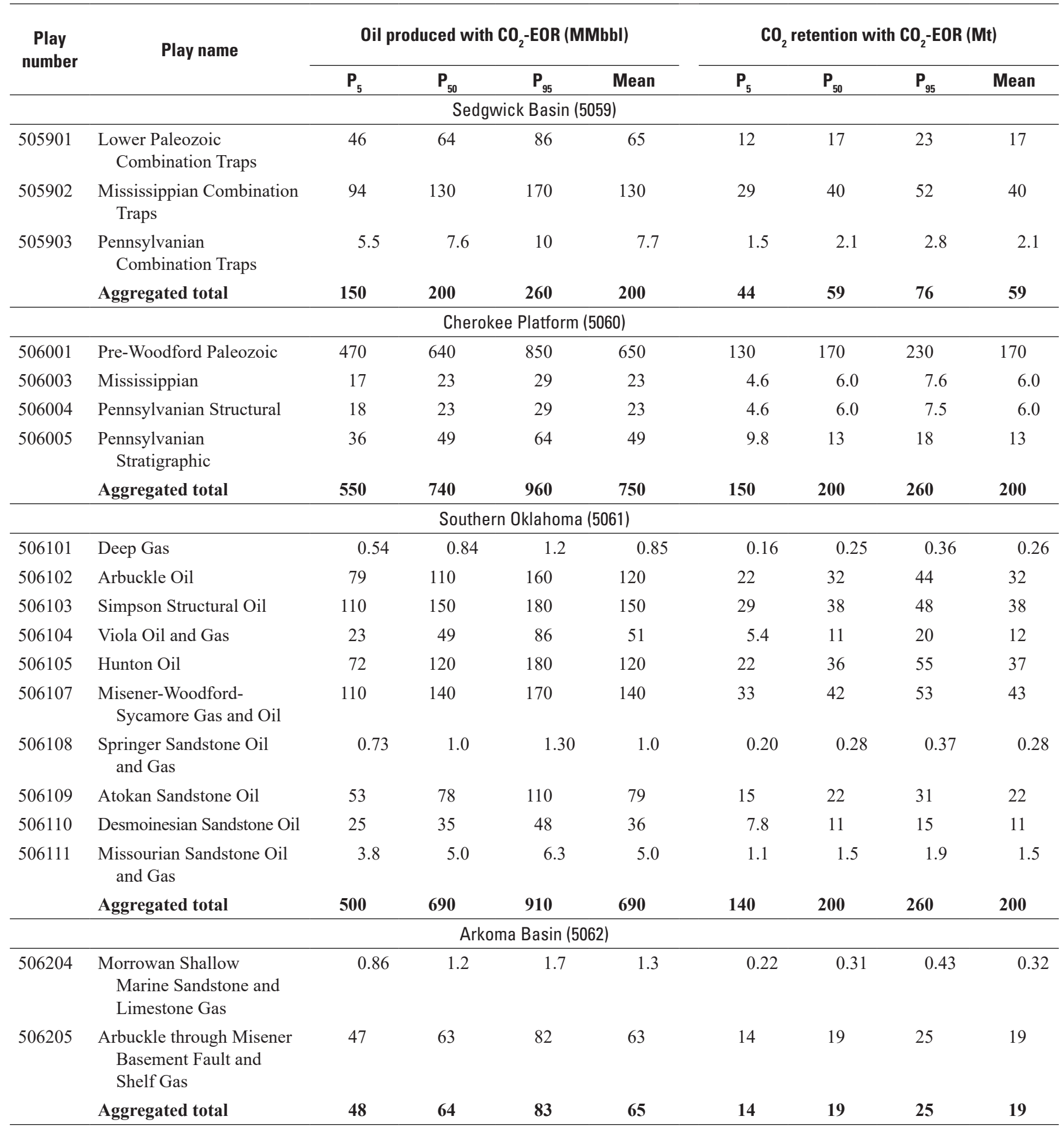


Table 6. Estimated volume of oil that could be produced with carbon dioxide enhanced oil recovery (CO 2 -EOR) and estimated mass of associated carbon dioxide $\left(\mathrm{CO}_{2}\right)$ that could be stored (retained) in existing reservoirs underlying onshore and State waters areas of the conterminous United States, aggregated by province and play.-Continued

[MMbbl, millions of petroleum barrels; Mt, millions of metric tons. Probability percentiles $\left(\mathrm{P}_{5}, \mathrm{P}_{50^{\prime}}\right.$ and $\left.\mathrm{P}_{95}\right)$ are defined on p. 29]

\begin{tabular}{|c|c|c|c|c|c|c|c|c|c|}
\hline \multirow{2}{*}{$\begin{array}{l}\text { Play } \\
\text { number }\end{array}$} & \multirow{2}{*}{ Play name } & \multicolumn{4}{|c|}{ Oil produced with $\mathrm{CO}_{2}$-EOR (MMbbl) } & \multicolumn{4}{|c|}{$\mathrm{CO}_{2}$ retention with $\mathrm{CO}_{2}-\mathrm{EOR}(\mathrm{Mt})$} \\
\hline & & $\mathbf{P}_{5}$ & $\mathbf{P}_{50}$ & $\mathbf{P}_{95}$ & Mean & $\mathbf{P}_{5}$ & $\mathbf{P}_{50}$ & $\mathbf{P}_{95}$ & Mean \\
\hline 506301 & Anticline & 95 & 130 & 170 & 130 & 30 & 40 & 53 & 41 \\
\hline 506307 & Northern Niagaran Reef & 39 & 58 & 83 & 59 & 15 & 22 & 32 & 23 \\
\hline \multirow[t]{2}{*}{506311} & Trenton-Black River & 62 & 84 & 110 & 85 & 18 & 25 & 33 & 25 \\
\hline & Aggregated total & 220 & 290 & 370 & 290 & 72 & 94 & 120 & 95 \\
\hline \multicolumn{10}{|c|}{ Illinois Basin (5064) } \\
\hline 506401 & $\begin{array}{l}\text { Illinois Basin-Post-New } \\
\text { Albany }\end{array}$ & 33 & 44 & 56 & 44 & 8.9 & 12 & 15 & 12 \\
\hline & Aggregated total & 84 & 110 & 140 & 110 & 23 & 29 & 37 & 29 \\
\hline \multicolumn{10}{|c|}{ Appalachian Basin (5067) } \\
\hline 506703 & $\begin{array}{l}\text { Beekmantown/Knox } \\
\text { Carbonate Oil/Gas }\end{array}$ & 22 & 28 & 35 & 28 & 6.1 & 8.1 & 10 & 8.1 \\
\hline 506732 & $\begin{array}{l}\text { Clinton/Medina Sandstone } \\
\text { Oil/Gas }\end{array}$ & 59 & 75 & 92 & 75 & 27 & 35 & 43 & 35 \\
\hline \multirow[t]{2}{*}{506737} & $\begin{array}{l}\text { Upper Devonian Sandstone } \\
\text { Oil/Gas }\end{array}$ & 15 & 18 & 22 & 18 & 4.8 & 6.1 & 7.4 & 6.1 \\
\hline & Aggregated total & 98 & 120 & 150 & 120 & 39 & 49 & 59 & 49 \\
\hline
\end{tabular}


For more information, please contact:

Program Coordinator

Energy Resources Program

U.S. Geological Survey

12201 Sunrise Valley Drive

Reston, VA 20192

Telephone: 703-648-6470

https://www.usgs.gov/energy-and-minerals/energy-resourcesprogram/connect

Publishing support provided by the Reston Publishing Service Center 


\section{$\frac{\mathbb{2}}{3}$}

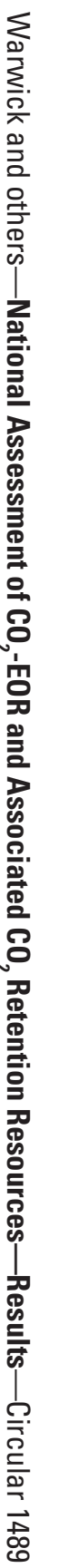

